\title{
Synthesis of $\mathrm{GABA}_{A}$ Receptor Agonists and Evaluation of their $\alpha-$ Subunit Selectivity and Orientation in the GABA Binding Site
}

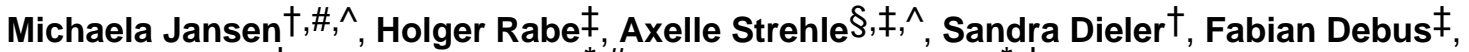 \\ Gerd Dannhardt ${ }^{\dagger}$, Myles H. Akabas ${ }^{\star}, \#$, and Hartmut Lüddens ${ }^{\star}, \ddagger$ \\ Department of Medicinal Chemistry and Department of Psychiatry, Johannes Gutenberg-University, \\ Mainz, Germany, and Departments of Physiology \& Biophysics, Neuroscience and Medicine, Albert \\ Einstein College of Medicine of Yeshiva University, Bronx, New York, USA
}

\begin{abstract}
Drugs used to treat various disorders target $\mathrm{GABA}_{\mathrm{A}}$ receptors. To develop $\alpha$ subunit selective compounds, we synthesized 5-(4-piperidyl)-3-isoxazolol (4-PIOL) derivatives. The 3-isoxazolol moiety was substituted by 1,3,5-oxadiazol-2-one, 1,3,5-oxadiazol-2-thione, and substituted 1,2,4triazol-3-ol heterocycles with modifications to the basic piperidine substituent as well as substituents without basic nitrogen. Compounds were screened by $\left[{ }^{3} \mathrm{H}\right]$ muscimol binding and in patch-clamp experiments with heterologously expressed $\mathrm{GABA}_{\mathrm{A}} \alpha_{\mathrm{i}} \beta_{3} \gamma_{2}$ receptors $(\mathrm{i}=1-6)$. The effects of 5aminomethyl-3H-[1,3,4]oxadiazol-2-one 5d were comparable to GABA for all $\alpha$ subunit isoforms. 5-piperidin-4-yl-3H-[1,3,4]oxadiazol-2-one 5a and 5-piperidin-4-yl-3H- [1,3,4]oxadiazol-2-thione 6a were weak agonists at $\alpha_{3}-, \alpha_{3}-$, and $\alpha_{5}$-containing receptors. When coapplied with GABA they were antagonistic in $\alpha_{2-}, \alpha_{4}-$, and $\alpha_{6}$-containing receptors and potentiated $\alpha_{3}$-containing receptors. 6a protected GABA binding site cysteine-substitution mutants $\alpha_{1} \mathrm{~F} 64 \mathrm{C}$ and $\alpha_{1} \mathrm{~S} 68 \mathrm{C}$ from reacting with methanethiosulfonate-ethylsulfonate. 6a specifically covalently modified the $\alpha_{1} \mathrm{R} 66 \mathrm{C}$ thiol, in the GABA binding site, through its oxadiazolethione sulfur. These results demonstrate the feasibility of synthesizing $\alpha$ subtype selective GABA mimetic drugs.
\end{abstract}

\section{Introduction}

$\gamma$-Aminobutyric acid type A receptors $\left(\mathrm{GABA}_{\mathrm{A}}\right)$ are responsible for most of the fast inhibitory synaptic transmission in mammalian brain. They belong to the Cys-loop receptor superfamily of ligand-gated ion channels. These receptors are formed by the pentameric assembly of homologous subunits and contain an anion-selective transmembrane channel. Numerous $\mathrm{GABA}_{\mathrm{A}}$ receptor subunits have been identified $\left(\alpha_{1-6}, \beta_{1-3}, \gamma_{1-3}, \delta \pi, \varepsilon\right.$ and $\left.\theta\right)$, all of which are products of separate genes ${ }^{1-3}$. Most $\mathrm{GABA}_{\mathrm{A}}$ receptors contain two $\alpha$, two $\beta$ subunits and either a $\gamma$ or a $\delta$ subunit. Recombinant $\mathrm{GABA}_{\mathrm{A}}$ receptors with different subunit isoform composition display differing sensitivity to the endogenous agonist GABA ${ }^{4}$. The $\mathrm{GABA}_{\mathrm{A}}$ receptor subunits exhibit distinct, although overlapping, regional distribution patterns within the brain, with expression patterns changing during pre- to postnatal development ${ }^{5}$. In addition, in neurons expressing multiple receptor isoforms, subunit-selective targeting to distinct cellular

\footnotetext{
*To whom correspondence should be addressed. Hartmut Lüddens, Tel.: +496131 175372. Fax: +496131 175590. Email: lueddens@unimainz.de. Myles H. Akabas, Tel.: +1 718430 3360. Fax: +1 718430 8819. Email: makabas@aecom.yu.edu.

Department of Medicinal Chemistry, University of Mainz, Germany

\$Department of Psychiatry, University of Mainz, Germany

\#Departments of Physiology \& Biophysics, Neuroscience and Medicine, Albert Einstein College of Medicine of Yeshiva University, Bronx, New York, USA

present addresses: MJ, Department of Physiology and Biophysics, Albert Einstein College of Medicine of Yeshiva University, Bronx, New York, USA; AS, Université Louis Pasteur, Strasbourg, France

$\$_{\mathrm{MJ}}$ and HR contributed equally to this study.
} 
domains has been observed 6,7 . The subunit isoform diversity and brain region specific expression patterns form the basis for the functional and pharmacological heterogeneity of GABAergic neurotransmission. Presently, most drug therapy for anxiety, epilepsy and surgical sedation and often for insomnia targets $\mathrm{GABA}_{\mathrm{A}}$ receptor subtypes non-selectively, but the heterogeneity of the receptors theoretically holds the promise for brain region- or even cellselective pharmacological intervention which would increase the specificity of the effects and decrease the incidence of undesirable side effects.

Most of the known pharmacological heterogeneity of $\mathrm{GABA}_{\mathrm{A}}$ receptors concerns the sensitivity of the benzodiazepine site that is formed at the interface between the $\alpha$ and $\gamma$ subunits ${ }^{8-10}$. Receptors lacking the $\gamma_{2}$ subunit or containing the $\alpha_{4}$ or $\alpha_{6}$ subunits are practically insensitive to benzodiazepine site agonists $11,12,13,14$. The two GABA binding sites are formed at the interfaces between the $\beta$ and $\alpha$ subunits. Only a few different structural classes of ligands are known for the GABA binding site, reflecting the strict structural requirements for $\mathrm{GABA}_{\mathrm{A}}$ receptor recognition and activation. To date these GABA binding site agonist compounds display little subunit subtype specificity with gaboxadol forming a class on its own as a "superagonistic" GABA mimetic 15 . A few compounds have been identified which neither bind to the benzodiazepine nor the GABA binding sites and yet still show subtype-selective antagonistic activity, these include furosemide, otherwise known as a $\mathrm{Na}^{+} / \mathrm{K}^{+} / 2 \mathrm{Cl}^{-}$cotransporter blocker, that selectively blocks $\alpha(4 / 6) \beta(2 / 3) \gamma_{2}$ receptors 16,17 , and clozapine, an atypical antipsychotic drug, that inhibits furosemide-insensitive $\alpha 1$ containing receptors ${ }^{18}$.

Undesirable side effects, such as sedation and amnesia, often limit the clinical use of benzodiazepines ${ }^{19}$, as well as the use of full agonists and of zero modulators of the GABA recognition site ${ }^{20}$. Different strategies exist to minimize undesirable effects: subtype-selective ligands or partial agonists. Studies with transgenic rodents have helped to dissect the $\alpha$-subunit isoforms involved in specific pharmacologic effect of benzodiazepines. For example, $\alpha_{2^{-}}$ containing receptors are primarily responsible for anxiolytic effects of benzodiazepines whereas $\alpha_{1}$-containing receptors are more important for the sedative side effects. Current research efforts focused on designing subunit-selective benzodiazepines ${ }^{21-27}$. In general, it seems desirable to have subtype-selective ligands that only act on a certain receptor subtype that is involved in transducing the desired effect and not on other subtypes that are involved in undesired effects. A complementary approach is to develop partial agonists of the GABA recognition site that induce only submaximal activation of specific $\alpha$-subunit containing receptors. Under close to complete receptor occupancy, these partial agonists act as inhibitors of full agonists ${ }^{15}$. Partial agonists at the benzodiazepine site have also been investigated ${ }^{28-}$ 30 .

In a previous study we used binding studies on rat brain cryostat sections and patch-clamp experiments with heterologously expressed recombinant $\mathrm{GABA}_{\mathrm{A}}$ receptors to characterize the low-efficacy GABA mimetic 5-(4-piperidyl)isoxazol-3-ol (4-PIOL) (Figure 1) as a weak partial agonist or antagonist depending on the brain area and the $\mathrm{GABA}_{\mathrm{A}}$ receptor composition $^{31,32}$. Therefore we synthesized and functionally characterized different 5-(4piperidyl)-1,3,4-oxadiazol- and 5-(4-piperidyl)-1,3,4-triazol-derivatives compounds structurally related to 4-PIOL ${ }^{33}$. The effects of other 4-PIOL derivatives on $\mathrm{GABA}_{\mathrm{A}}$ receptors have been studied previously ${ }^{34-40}$. All compounds were screened for efficacy and potency to $\mathrm{GABA}_{\mathrm{A}}$ receptors in native membranes using a $\left[{ }^{3} \mathrm{H}\right]$ muscimol binding assay. Substances inducing changes in $\left[{ }^{3} \mathrm{H}\right]$ muscimol binding in the micromolar concentration range were further analyzed in patch clamp recordings from $\mathrm{GABA}_{\mathrm{A}}$ receptors heterologously expressed in human embryonic kidney (HEK 293) cells. The $\alpha$ subunit specificity of these compounds was tested in $\alpha_{i} \beta_{3} \gamma_{2}(i=1-6) G_{A B A}$ receptors by measuring the modulation of GABA-induced chloride current and the intrinsic activity of the compounds. We also sought to demonstrate 
that the actions of these new compounds were mediated through binding at the GABA-binding sites. We used a variant of the substituted cysteine accessibility method (SCAM) in order to identify the position and orientation of $\mathbf{6 a}$ in the binding site ${ }^{41}$. Residues in the $\alpha$ subunit that line the GABA binding site have been identified based on the effects of mutations on electrophysiological properties ${ }^{42-44}$, photo-affinity labeling 45 and SCAM $46-48$. They include those aligned with rat $\alpha_{1}$ positions F64, R66, S68 and T129. Although crystal structures of $\mathrm{GABA}_{\mathrm{A}}$ receptor binding sites are not yet available, homology models based on the snail acetylcholine binding protein $(\mathrm{AChBP})$ structure provide a reasonable molecular context in which to interpret our results 49 .

\section{Synthesis}

The synthetic procedures for the 5-(4-piperidyl)-1,3,4-oxadiazole- and 5-(4-piperidyl)-1,3,4triazole-derivatives in this study are depicted in scheme 1 and scheme 2, whereas schemes 3 and 4 depict specific variations of the 4-piperidyl moiety. Here we describe the synthesis of the 4-piperidyl-derivatives as an example. The secondary amine function of 4-piperidinecarboxylic acid ester was either protected with the $t$-butoxycarbonyl (Boc) group using di- $t$ butyldicarbonate and $\mathrm{NaHCO}_{3}$ in water or triethylamine in methylene chloride (Scheme 1: 1a) or alkylated using formaldehyde, formic acid or benzylchloride (Scheme 2: 7a, b). Subsequently, the esters were converted to the corresponding acid hydrazides (Scheme 1: 2a; Scheme 2: 8a, b) by refluxing the ester in an excess of hydrazine hydrate. The 1,3,4oxadiazol-2-ones (Scheme 1: 3a; Scheme 2: 9a, b) were prepared by refluxing the hydrazides with $\mathrm{N}, \mathrm{N}^{\prime}$-carbonyldiimidazol (CDI) in the presence of triethylamine in a mixture of THF and DMF. The corresponding 1,3,4-oxadiazol-2-thiones (Scheme 1: 4a; Scheme 2: 10a, b) were synthesized by refluxing the hydrazides with carbonyldisulfide in an ethanolic potassium hydroxide solution. Theoretically, oxadiazol-2-ones and -thiones can exist in two tautomeric forms, the amide form and the imino-alcohol form. IR, UV and NMR spectra, however, indicate that they exist predominantly in their amide-form ${ }^{50}$. The hydrazide $2 \mathbf{a}$ was also cyclized with triethoxyethane to yield the 2-methyl-1,3,4-oxadiazol-derivative (Scheme 1: 18). Reaction of the hydrazide 2a with benzylisocyanate or benzylisothiocyanate produced the acylated semicarbazide derivatives 12a and 13a, which were converted to benzyl-1,3,4-oxadiazoles 14 and 15 by refluxing with $\mathrm{NaOH}$ in an aqueous solution (Scheme 1). N-methyl-piperidin-4yl carboxylic acid hydrazide (8b) was reacted with triethoxymethane to yield the 2unsubstituted 1,3,4-oxadiazol-derivative $\mathbf{1 1}$ (Scheme 2). The 4-piperidyl moiety was varied as outlined in Scheme 3 and 4. It was substituted by a 3-piperidyl and a 2-pyrrolidinyl moiety, or residues that lead to derivatives that mimic glycine, sarcosine, alanine and $\beta$-alanine (Scheme 3 ) as well as N-alkylated 4-piperidinyl-compounds, dimethylglycine and two compounds without an amine function (Scheme 4). The last step during the synthesis of compounds 5ag, 6a-e, g, 16a, 17a, and 19 was the removal of the Boc-protective group with hydrogen chloride (Scheme 1 and 3).

\section{Pharmacology $\left[{ }^{3} \mathrm{H}\right]$ Muscimol binding}

Compounds were initially screened by probing their ability to compete with $\left[{ }^{3} \mathrm{H}\right] \mathrm{muscimol}$ binding to the GABA recognition site in native cortical and cerebellar membranes. We used two concentrations ( $100 \mu \mathrm{M}$ and $1 \mathrm{mM}$ ) of the compounds. This approach allowed us to eliminate compounds with very low binding affinity. Additionally, we compared the binding of $\left[{ }^{3} \mathrm{H}\right]$ muscimol to membranes from two brain structures: cortex, containing $\alpha_{1}-\alpha_{5}$ receptors, and cerebellum, enriched in $\alpha_{1}$ - and the exclusive source of $\alpha_{6}$-containing $\mathrm{GABA}_{\mathrm{A}}$ receptors (Table 1), to enable us to detect pronounced differences in subtype selectivity of the compounds. 
Of the 28 compounds tested, six fulfilled our criteria for full binding analysis in that, at 100 $\mu \mathrm{M}$, they inhibited muscimol binding by at least $30 \%$ (Table 1). These six included 5a, 5d, $5 \mathbf{5}, 6 \mathbf{6 a}, \mathbf{6 d}$ and 19. For these compounds we determined the $\mathrm{IC}_{50}$ values for inhibition of $\left[{ }^{3} \mathrm{H}\right]$ muscimol binding to cortical and cerebellar membranes (Table 2, 5d Figure 2). showed the highest affinity with an $\mathrm{IC}_{50}$ of $1.4 \mu \mathrm{M}$ and $\mathbf{5 a}$ exhibited the lowest affinity, $183 \mu \mathrm{M}$ (Table 2 ). None of the six compounds displayed significant differences between $\mathrm{IC}_{50}$ determined in cortical vs cerebellar membranes, though compound $\mathbf{5 g}$ showed a significant difference between the pseudo-Hill coefficient determined in cortical vs cerebellar membranes, 0.63 vs 0.92 , respectively, whereas no difference in any measure was detected for the other compounds (Table 2).

\section{HEK293 Electrophysiology}

We characterized the functional effects of four compounds on $\alpha_{i} \beta_{3} \gamma_{2}(i=1-6) G A B A_{A}$ receptors using patch-clamp experiments with heterologously expressed $\mathrm{GABA}_{\mathrm{A}}$ receptors. This allowed us to determine directly the $\mathrm{GABA}_{\mathrm{A}}$ receptor $\alpha$ subunit specificity for these four compounds identified as the most potent inhibitors in the $\left[{ }^{3} \mathrm{H}\right]$ muscimol binding assays described above. Transiently transfected HEK 293 cells co-expressing an $\alpha$ variant plus $\beta_{2}$ and $\gamma_{2} \mathrm{~S}$ and Enhanced Green Fluorescent Protein (EGFP) were used in these experiments. EGFP fluorescence facilitated the identification of transfected cells for patch clamping. For each compound we applied a series of increasing drug concentrations either alone, to assess the intrinsic agonist activity, or together with the approximate $\mathrm{EC}_{20}$ to $\mathrm{EC}_{25}$ concentration of GABA, to determine its GABA-modifying activity. The GABA EC $20-25$ concentrations used for the different $\alpha$ subunits are shown in Table 3 .

\section{Intrinsic agonist activity}

5a (5-Piperidin-4-yl-3H-[1,3,4]oxadiazol-2-one hydrochloride) and 6a (5-Piperidin-4-yl-3H$[1,3,4]$ oxadiazol-2-thione Hydrochloride) showed limited intrinsic activity in $\alpha_{1}, \alpha_{4}$, and $\alpha_{6}$ containing receptors (Figure 3). At $1 \mathrm{mM}$ the induced currents were less than $10 \%$ of the currents induced by the approximate $\mathrm{EC}_{100} \mathrm{GABA}$ concentrations (Figure 4). In contrast, on $\alpha_{2}, \alpha_{3}$, and $\alpha_{5}$ containing receptors, $1 \mathrm{mM} 5$ a caused currents of $17 \pm 1 \%, 18 \pm 2 \%$, and $34 \pm$ $3 \%$ of the maximal GABA-induced currents. On the same receptors $1 \mathrm{mM}$ 6a induced currents that were $23 \pm 5 \%, 13 \pm 2 \%$, and $48 \pm 4 \%$ of the maximal GABA-induced currents.

5d (5-Aminomethyl-3H-[1,3,4] oxadiazol-2-one hydrochloride) induced desensitizing currents in all $\mathrm{GABA}_{\mathrm{A}}$ receptor combinations tested in a dose-dependent manner with an efficacy $>50 \%$ of the maximal GABA-induced currents and an $\alpha$ subunit specific potency (Table 4, Figure 3). Receptors containing $\alpha_{6}$ subunits were most sensitive with an $\mathrm{EC}_{50}$ of $30 \mu \mathrm{M}$ and receptors containing the $\alpha_{3}$ subunit were the least sensitive with a $\mathbf{5 d ~ E C _ { 5 0 }}$ of ca. $2300 \mu \mathrm{M}$.

The ability of $\mathbf{1 9}$ (4-(5-Methyl-[1,3,4] oxadiazol-2-yl)-piperidine hydrochloride) to directly activate $\mathrm{GABA}_{\mathrm{A}}$ receptors was restricted to $\alpha 6$ containing receptors where it induced currents $29 \pm 4 \%$ of the maximal GABA-evoked currents. With all of the other $\alpha$ subunits $1 \mathrm{mM} 19$ induced a current less than $10 \%$ of the maximal GABA-induced current.

\section{GABA modulatory effect}

5a showed a slight dose-dependent potentiating effect on $\alpha_{3}$ and $\alpha_{5}$ containing GABA receptors with maximal current potentiation by $1 \mathrm{mM} \mathbf{5 a}$ of $22 \pm 11 \%$ for $\alpha_{3}$ and $34 \pm 5 \%$ for $\alpha_{5}$ containing receptors (Figure 4). In all other $\alpha$ subunits its action was antagonistic on GABAinduced currents with similar potency. Its antagonistic efficacy was highest in $\alpha_{1}$ containing receptors where $1 \mathrm{mM} 5 \mathbf{5 a}$ inhibited GABA-induced current by $77 \pm 3 \%$. At this concentration 5a inhibited GABA-induced currents of other $\alpha$ subunits by $42 \pm 2 \%$ for $\alpha_{2}, 52 \pm 5 \%$ for $\alpha_{4}$, and $41 \pm 4 \%$ for $\alpha_{6}$. 
6a (5-Piperidin-4-yl-3H-[1,3,4]oxadiazol-2-thione hydrochloride), the thio-derivative of 5a, had similar effects to $\mathbf{5 a}$ except on $\alpha_{2}$ containing receptors. $\mathbf{6 a}$ potentiated GABA-induced currents in $\alpha_{5} \beta_{3} \gamma_{2}$ receptors to an extent similar to that described for $\mathbf{5 a}$, but on $\alpha_{3} \beta_{3} \gamma_{2}$ receptors the potentiating effect of $\mathbf{6 a}$ was higher with a current potentiation of $114 \pm 8 \%$ at $1 \mathrm{mM}$. In contrast to $\mathbf{5 a}$, in $\alpha_{2}$-containing receptors, low concentrations of $\mathbf{6 a}$ potentiated submaximal GABA-induced currents with maximal potentiation of $39 \pm 4 \%$ at $1 \mu \mathrm{M}$. Whereas at $1 \mathrm{mM}$, 6a inhibited GABA currents by $24 \pm 9 \%$. 6a also inhibited GABA-induced currents in $\alpha_{1}$, $\alpha_{4}$, and $\alpha_{6}$ containing receptors.

5d(5-Aminomethyl-3H-[1,3,4] oxadiazol-2-one hydrochloride), potentiated the GABAinduced currents for all of the $\alpha$ subunit isoforms with similar potency, apparent $\mathrm{EC}_{50}$ values ranged between 100 and $300 \mu \mathrm{M}$ (Figure 3). The efficacy was similar in $\alpha_{1}, \alpha_{2}, \alpha_{3}$, and $\alpha_{4}$ containing receptors with current potentiation of $302 \pm 35 \%, 324 \pm 40 \%, 311 \pm 18 \%$, and 334 $\pm 13 \%$ at $1 \mathrm{mM}$, respectively. The $\mathbf{5 d}$ efficacy was significantly enhanced in receptors comprising $\alpha 5(423 \pm 25 \%)$ and $\alpha_{6}(437 \pm 21 \%)$ subunits with $p$ of $<0.01$ in a two-sided t-test compared to $\alpha_{1}$ containing receptors.

Lastly, we analyzed the $\mathrm{GABA}_{\mathrm{A}}$ receptor $\alpha$ subunit specificity of 19 (4-(5-methyl-[1,3,4] oxadiazol-2-yl)-piperidine hydrochloride) and its hydrobromide with electrophysiological methods. This novel compound increased the GABA-induced currents in all $\mathrm{GABA}_{\mathrm{A}}$ receptor combinations tested with similar potency. The efficacy shows a slight subtype specificity which could be divided into two significantly different groups with $\mathrm{p}$ of $<0.01$ in a two-sided t-test. The group with higher efficacy consisting of $\alpha_{2}, \alpha_{4}, \alpha_{5}$, and $\alpha_{6}$ with positive modulation of the GABA-induced currents ranging from $48 \%$ in $\alpha_{2}$ to $87 \%$ in $\alpha_{6}$ at $1 \mathrm{mM} \mathrm{19}$. The positive modulation efficacy was smaller for $\alpha_{3}$ and $\alpha_{1}$ containing receptors where compound 19 potentiated the GABA-induced currents by $11 \% \pm 2$ and by $21 \% \pm 5$, respectively.

\section{Two-Electrode Voltage Clamp Electrophysiology in Xenopus laevis oocytes}

Based on the diverse set of effects, potentiation, inhibition and direct activation, seen with the compounds we sought to demonstrate that they bound in the GABA binding site. These experiments focused on compound 6a. We used a series of cysteine-substitution mutants in the GABA binding site.

Determination of $\mathrm{GABA} \mathrm{EC}_{\mathbf{5 0}}$ values-GABA dose-response relationships were determined for wild type and mutant $\alpha_{1} \beta_{2}$ receptors expressed in Xenopus oocytes (Table 5). Mutant $\alpha_{1} \mathrm{~S} 68 \mathrm{C} \beta_{2}$ receptors had an $\mathrm{EC}_{50}$ value comparable to $\alpha_{1} \beta_{2}$ wt receptors. In contrast, the $\mathrm{EC}_{50}$ values for the mutants $\alpha_{1} \mathrm{~T} 129 \mathrm{C} \beta_{2}, \alpha_{1} \mathrm{~F} 64 \mathrm{C} \beta_{2}$ and $\alpha_{1} \mathrm{R} 66 \mathrm{C} \beta_{2}$ were increased 14 -fold, 43-fold and 554-fold, respectively, compared to wild type, in agreement with previously published data 46,47 .

Determination of $\mathbf{6} \mathbf{a} \mathbf{E C}_{\mathbf{5 0}}-\mathbf{6 a}$ acted as an agonist on $\alpha_{1} \beta_{2}$ wt, $\alpha_{1} \mathrm{~F} 64 \mathrm{C} \beta_{2}$, and $\alpha_{1} \mathrm{~S} 68 \mathrm{C} \beta_{2}$ receptors. To prove that the $\mathbf{6 a}$-induced currents were mediated by $\mathrm{GABA}_{\mathrm{A}}$ receptor activation we tested the ability of picrotoxinin, an open channel blocker, to inhibit the 6a induced currents. Co-application of $100 \mu \mathrm{M}$ picrotoxinin and $10 \mathrm{mM}$ 6a inhibited 6a-induced currents by 80 $90 \%$ (Figure 5). We infer that $6 \mathbf{a}$ directly activates $\mathrm{GABA}_{\mathrm{A}}$ receptors.

We determined the $\mathbf{6 a} \mathrm{EC}_{50}$ for the Cys-substitution mutant receptors (Table 5). For wt receptors the $\mathbf{6 a} \mathrm{EC}_{50}$ was $9.5 \mathrm{mM}$. It was similar for $\alpha_{1} \mathrm{~S} 68 \mathrm{C} \beta_{2}$. For $\alpha_{1} \mathrm{~F} 64 \mathrm{C} \beta_{2}$, the $\mathbf{6 a} \mathrm{EC}_{50}$ was 0.6 fold less than for wt.

The efficacy of $6 \mathbf{a}$ as compared to GABA was significantly greater for $\alpha_{1} \mathrm{~F} 64 \mathrm{C} \beta_{2}$ receptors compared to $\alpha_{1} \beta_{2}$ wt and $\alpha_{1} \mathrm{~S} 68 \mathrm{C} \beta_{2}$. A $30 \mathrm{mM}$ concentration of 6 a produced currents that were 60,20 , and $17 \%$ as large as the maximal GABA current for $\alpha_{1} \mathrm{~F} 64 \mathrm{C} \beta_{2}, \alpha_{1} \beta_{2}$ wt, and 
$\alpha_{1} \mathrm{~S} 68 \mathrm{C} \beta_{2}$ receptors, respectively. Higher concentrations of $\mathbf{6 a}$ were not used due to the limited supply of the compound. The Hill coefficient of the 6a dose-response relationship was increased compared to GABA.

Determination of $6 \mathbf{~} \mathbf{I C}_{50}$ values of the mutants-Co-application of $\mathbf{6 a}$ and GABA inhibited the GABA-induced currents. We performed competition experiments to determine the 6a IC $\mathrm{IC}_{50}$ for inhibiting GABA EC 20 currents with $\alpha_{1} \beta_{2}$ wt, $\alpha_{1} \mathrm{~F} 64 \mathrm{C} \beta_{2}$, and $\alpha_{1} \mathrm{~S} 68 \mathrm{C} \beta_{2}$ receptors (Table 5). One $\mathrm{mM} 6 \mathbf{6}$ inhibited the $\mathrm{EC}_{20} \mathrm{GABA}$ current by more than $90 \%$ in these receptors. The residual GABA currents observed during the co-application of $1 \mathrm{mM}$ 6a and $\mathrm{GABA} \mathrm{EC}_{20}$ concentration, were $6.8 \pm 1.0 \%(\mathrm{n}=4)$ for $\alpha_{1} \beta_{2} \mathrm{wt}, 9.0 \pm 2.0 \%(\mathrm{n}=3)$ for $\alpha_{1} \mathrm{~F} 64 \mathrm{C} \beta_{2}$, and $3.0 \pm 1.8 \%(\mathrm{n}=6)$ for $\alpha_{1} \mathrm{~S} 68 \mathrm{C} \beta_{2}$. Since the $\mathbf{6 a}-\mathrm{GABA}$ competition experiments were done at a relatively low GABA concentration we decided that for the protection experiments the $\mathbf{6 a}$ concentration should be at least $1 \mathrm{mM}$.

\section{Effects of MTS-reagents on the cysteine mutants and reaction rates-}

Methanethiosulfonate (MTS) reagents react $10^{9}$ times faster with ionized thiolates $\left(\mathrm{S}^{-}\right)$than with thiols (SH) 51 ; thus, they are much more likely to react with water-accessible cysteine, which can ionize. We monitored the MTS reaction with a substituted cysteine by its affect on the channel's macroscopic currents.

Application of the anionic reagent MTS-ethylsulfonate $\left(\right.$ MTSES $^{-}$) did not affect the GABA current in $\alpha_{1} \beta_{2}$ wt receptors (data not shown) ${ }^{46}$. After complete reaction with MTSES $^{-}$and/ or MTSEA-biotin, subsequent GABA EC $\mathrm{C}_{50}$ currents were inhibited to a similar extent for $\alpha_{1} \mathrm{~F} 64 \mathrm{C} \beta_{2}, \alpha_{1} \mathrm{R} 66 \mathrm{C} \beta_{2}, \alpha_{1} \mathrm{~S} 68 \mathrm{C} \beta_{2}$ and $\alpha_{1} \mathrm{~T} 129 \mathrm{C} \beta 2$ receptors (see Table 6). We infer that in the cysteine-substitution mutants, changes in the GABA-induced current after MTS application were due to the covalent modification of the engineered cysteine.

The observed second-order rate constants for reaction with $\mathrm{MTSES}^{-}$were $11300 \pm 700 \mathrm{M}^{-1}$ / s for $\alpha_{1} \mathrm{~F} 64 \mathrm{C} \beta_{2}, 48 \pm 7 \mathrm{M}^{-1} / \mathrm{s}$ for $\alpha_{1} \mathrm{R} 66 \mathrm{C} \beta_{2}$, and $240 \pm 40 \mathrm{M}^{-1} / \mathrm{s}$ for $\alpha_{1} \mathrm{~S} 68 \mathrm{C} \beta_{2}$, which are in agreement with previously reported results (Table 7, Figure 6) ${ }^{46}$. For $\alpha_{1} R 66 C \beta_{2}$ and $\alpha_{1} \mathrm{~T} 129 \mathrm{C} \beta_{2}$ the second-order reaction rate constant for MTSEA-biotin with $\alpha_{1} \mathrm{R} 66 \mathrm{C} \beta_{2}$ was $5500 \pm 1600 \mathrm{M}^{-1} / \mathrm{s}$ and with $\alpha_{1} \mathrm{~T} 129 \mathrm{C} \beta_{2}$ was $6,700,000 \pm 1,100,000 \mathrm{M}^{-1} / \mathrm{s}$ (Table 6). All reaction rates were well fit by a mono-exponential function. For each mutant receptor, however, there are two engineered cysteine residues, because $\alpha \beta$-receptors are pentameric and their subunit stoichiometry is proposed to be $2 \alpha: 3 \beta 52,53$. Either the two cysteine residues from each receptor reacted at the same rate, or reaction at only one residue gave the complete effect. These two possibilities are indistinguishable with the present methods.

Protection of cysteine mutants by GABA and 6a-If an engineered cysteine forms part of a ligand-binding site, then the presence of the ligand in the binding site should reduce the ability of MTS reagents to react with the cysteine. This should decrease the measured MTS reaction rate in the presence of the ligand. It was reported previously that in the presence of GABA $\alpha_{1} \mathrm{~F} 64 \mathrm{C}, \alpha_{1}$ R66C, and $\alpha_{1} \mathrm{~S} 68 \mathrm{C}$ are protected from reaction with MTS reagents (MTSEA-biotin, MTSES $^{-}$, MTSEA $^{+}$) 46,47 . This protection may be due either to direct steric protection due to the presence of GABA in the binding site or to a GABA-induced conformational change reducing the accessibility of these residues to the MTS reagent. The fact that these cysteine mutants were also protected from modification by SR-95531, a competitive antagonist, implies that the mechanism of protection is a steric not an allosteric one 46,47 .

$\alpha_{1} \mathrm{~F} 64 \mathrm{C} \beta_{2}$ and $\alpha_{1} \mathrm{~S} 68 \mathrm{C} \beta_{2}$ receptors were protected from reaction with MTSES $^{-}$by both GABA and 6a (Figure 7 and 8). In control experiments with $\alpha_{1} \mathrm{~F} 64 \mathrm{C} \beta_{2}$, a $12 \mathrm{~s}$ application of $10 \mu \mathrm{M}$ MTSES $^{-}$caused an $87 \pm 3 \%(n=4)$ reduction in subsequent $\mathrm{GABA} \mathrm{EC}_{50}$ test currents (Figure 
7A). In contrast, a $12 \mathrm{~s}$ co-application of $10 \mu \mathrm{M} \mathrm{MTSES}^{-}$with $3.6 \mathrm{mM} \mathrm{GABA}$ caused only a $35 \pm 1 \%(\mathrm{n}=5)$ reduction of the subsequent GABA-induced currents (Figure 7B) and coapplication of $10 \mu \mathrm{M} \mathrm{MTSES}^{-}$with $10 \mathrm{mM}$ 6a resulted in only a $47 \pm 6 \%(\mathrm{n}=4)$ reduction (Figure 7C) of the subsequent GABA-induced currents. Thus, the extent to which MTSES ${ }^{-}$ could react with $\alpha_{1} \mathrm{~F} 64 \mathrm{C} \beta_{2}$ was reduced by the presence of GABA and $\mathbf{6 a}$. This implies that both agonists protected the engineered cysteine from covalent modification.

Similarly for the $\alpha_{1} \mathrm{~S} 68 \mathrm{C} \beta_{2}$ mutant, application of $450 \mu \mathrm{M} \mathrm{MTSES}^{-}$for $12 \mathrm{~s}$ reduced the subsequent GABA test currents by $77 \pm 5 \%(\mathrm{n}=4)$ (Figure 8$)$. Co-application of $450 \mu \mathrm{M}$ MTSES $^{-}$with $65 \mu \mathrm{M}$ GABA or $10 \mathrm{mM}$ 6a only reduced the subsequent GABA test currents by $40 \pm 2 \%(n=4)$ and $10 \pm 4 \%(n=4)$, respectively, consistent with protection of the $\alpha_{1} \mathrm{~S} 68 \mathrm{C}$ cysteine residue.

In similar experiments with $\alpha_{1} \mathrm{R} 66 \mathrm{C} \beta_{2}$ receptors, $10 \mathrm{mM} \mathrm{6a}$ demonstrated slight, but significant protection of the engineered cysteine from reaction with $\mathrm{MTSES}^{-}$(Figure 8). A $12 \mathrm{~s}$ application of $2 \mathrm{mM} \mathrm{MTSES}^{-}$to $\alpha_{1} \mathrm{R}_{66 \mathrm{C}} \beta_{2}$ inhibited $91 \pm 3 \%(\mathrm{n}=6)$ of the subsequent GABA EC 50 current. Co-application of $35 \mathrm{mM}$ GABA with MTSES $^{-}$inhibited $49 \pm 6 \%(\mathrm{n}=3)$ of the subsequent test currents, consistent with protection by GABA. In contrast, application of 10 mM 6a with $2 \mathrm{mM} \mathrm{MTSES}^{-}$resulted in $77 \pm 4 \%(\mathrm{n}=5)$ inhibition of the subsequent GABA test currents. Comparable results were obtained for MTSEA-biotin, application of $30 \mathrm{mM}$ 6a with MTSEA-biotin resulted in 79 and $87 \%(\mathrm{n}=2)$ inhibition of the subsequent GABA test currents as compared to 87 and $100 \%(n=2)$ inhibition in control experiments. For $\alpha_{1}$ R66C the results of the protection experiments are complicated by the fact that $6 \mathbf{a}$ reacts with $\alpha_{1} \mathrm{R} 66 \mathrm{C} \beta_{2}$ as described below.

6a reacts with the engineered cysteine in $\alpha_{1} R 66 C \beta_{2}$ receptors-To our surprise, while examining competition between GABA and $6 \mathbf{a}$ on $\alpha_{1} R 66 C \beta_{2}$ receptors, we noted that once the oocytes showed stable GABA test responses, co-application of GABA and $\mathbf{6 a}$ irreversibly reduced the subsequent GABA test currents (data not shown). Alternating between GABA and 6a resulted in a progressive decline in the GABA test currents that finally led to a stable GABA current that was significantly lower, $68 \pm 4 \%(n=4)$, than the initial GABA test current (Figure 9A). At this stage, application of MTSES $^{-}$caused no further effect. In contrast, application of $\mathrm{MTSES}^{-}$to $\alpha_{1} \mathrm{R}_{66 \mathrm{C}} \beta_{2}$ expressing oocytes untreated with 6a produced $62 \pm 3 \%$ $(n=4)$ inhibition of GABA currents. Furthermore, the GABA currents after either $\mathbf{6 a}$ or MTSES $^{-}$application could be recovered by application of the reducing agent DTT $(10 \mathrm{mM}$, 20 s) (Figure 9A). Theoretically, oxadiazole-2-thiones, such as 6a, can exist in two tautomeric forms, the thio-amide (thione) form and the imino-thiol form. IR, UV and NMR spectra indicate that they do exist predominantly in their thione-form ${ }^{50}$. However, the ability to form the thioltautomer enables the oxadiazole-2-thione to form a disulfide bond. Consistent with the idea of the formation of a stable disulfide bond, repeated $10 \mathrm{~s}$ applications of $30 \mathrm{mM} 5 \mathbf{a}$, a $\mathbf{6 a}$ analogue with an oxygen in place of the potentially sulfhydryl reactive oxadiazolethione sulfur moiety, did not irreversible alter the subsequent GABA currents in $\alpha_{1} R 66 C \beta_{2}$ expressing oocytes (Figure 9B).

In order to measure the reaction rate of $6 \mathbf{a}$ with $\alpha_{1} \mathrm{R} 66 \mathrm{C}$ we alternately applied 5.5 mM GABA and 6a to oocytes until the GABA currents no longer declined (Figure 9A). The decline in the $\alpha_{1} R 66 C \beta_{2}$ GABA currents as a function of the cumulative $6 \mathbf{a}$ exposure time could be fit with a single exponential decay function. $\mathbf{6 a}$ second-order reaction rate with the engineered cysteine in $\alpha_{1} \mathrm{R} 66 \mathrm{C}$ was $5 \pm 1 \mathrm{M}^{-1} / \mathrm{s}(\mathrm{n}=3)$ (Figure $\left.9 \mathrm{~A}, \mathrm{C}\right)$. The second-order reaction rate constant was independent of the $6 \mathbf{a}$ concentration used (either 10 or $30 \mathrm{mM}$ ).

In our homology model based on the AChBP structure the $\alpha_{1}$ subunit residues R66 and T129 are in close proximity but on adjacent $\beta$-strands. Based on protection with agonist and 
antagonist SCAM analysis predicts that $\alpha_{1}$ T129 lines the binding pocket ${ }^{48}$. A 2 -min application of $5 \mathrm{mM} \mathrm{MTSES}^{-}$reduced the subsequent currents elicited by $\mathrm{GABA} \mathrm{EC}_{50}$ test pulses in $\alpha_{1} \mathrm{~T} 129 \mathrm{C} \beta_{2}$ by $63 \pm 5 \%(\mathrm{n}=3)$. We tested whether $6 \mathbf{a}$ would react with $\alpha_{1} \mathrm{~T} 129 \mathrm{C}$. Alternate application of $\mathrm{EC}_{50} \mathrm{GABA}$ and $30 \mathrm{mM} \mathbf{6 a}$ did not lead to a change in GABA $\mathrm{EC}_{50}$ peak currents in $\alpha_{1} \mathrm{~T} 129 \mathrm{C} \beta_{2}, \alpha_{1} \mathrm{~F} 64 \mathrm{C} \beta_{2}$, or $\alpha_{1} \mathrm{~S} 68 \mathrm{C} \beta_{2}$ containing receptors, suggesting that the reaction of $6 \mathbf{a}$ with $\alpha_{1} \mathrm{R} 66 \mathrm{C}$ is highly specific. It should be noted that the MTSES reaction rate with $\alpha_{1} \mathrm{R} 66 \mathrm{C}$ was at least 5-fold slower than with any of the other cysteine mutants used in this study (Table 6). It was orders of magnitude slower than the reaction rate with $\alpha_{1}$ T129C. Thus, the lack of $\mathbf{6 a}$ reaction with the other cysteine mutants is not due to lower intrinsic reactivity of those positions.

\section{Discussion}

\section{Structure-Activity relationships of 1,3,4-oxadiazol-2-ones}

The 1,3,4-oxadiazol-2-one compound with the highest affinity as measured by inhibiting muscimol binding is the aminomethyl-derivative $\mathbf{5 d}$ with $\mathrm{IC}_{50}$ values of $1.4 \mu \mathrm{M}$ and $1.1 \mu \mathrm{M}$ against rat cortex and cerebellum, respectively. The homo-derivative $\mathbf{5 g}$ with its 2 -aminoethyl side chain displayed seven times higher $\mathrm{IC}_{50}$ values. The conversion of the primary amine function of $\mathbf{5 d}$ to a secondary methylaminomethyl group in $\mathbf{5 e}$ caused a significant decrease in affinity and the tertiary dimethylaminomethyl compound $9 \mathbf{c}$ showed negligible capacity to displace $\left[{ }^{3} \mathrm{H}\right]$ muscimol. Thus, the affinity among the 5 -aminomethyl-3H-[1,3,4]oxadiazol-2ones decreases from the primary aminomethyl $\mathbf{5 d}$ over the secondary methylaminomethyl $\mathbf{5 g}$ to the tertiary dimethylaminomethyl 9c. We infer that the amino group is involved in interactions with the binding site because the cyclohexyl- 9d and methyl 9e substituted oxadiazol-2-ones that lack an amino group do not show significant inhibition of muscimol binding.

An additional steric demand at the methylene group of the aminomethyl compound $\mathbf{5} \mathbf{d}$ that led to the 1-aminoethyl derivative $\mathbf{5 f}$ was not well tolerated, i.e., the methyl group in $\mathbf{5 f}$ led to a significant decrease in the ability to displace $\left[{ }^{3} \mathrm{H}\right]$ muscimol. The 2-pyrrolidine compound $\mathbf{5 c}$, which can be considered as a bridged aminomethyl derivative of $\mathbf{5 d}$, showed an almost complete loss of affinity. In $\mathbf{5 c}$ the inhibition reducing effects of a secondary amine function and a steric strain added to the methylene group are combined. Similarly, when the 2aminoethyl sidechain was incorporated into a 3-piperidyl ring as in $\mathbf{5 b}$, the compound was inactive. However, the 4-piperidyl compound 5a, was active although the $\mathrm{IC}_{50}$ was increased by a factor of four when compared to the 2 -aminoethyl compound $\mathbf{5 g}$. Thus, the affinity appears to be sensitive to the position of the amino group because when it is at the 4 position in the piperidyl ring as in $\mathbf{5 a}$ the $\mathrm{IC}_{50}$ was $183 \mu \mathrm{M}$ but when located at the 3 position in $\mathbf{5 b}$ the affinity was negligible. Furthermore, derivatives of the 4-piperidyl amino group leading to tertiary amines in the form of the $\mathrm{N}$-benzyl-piperidine $\mathbf{9 b}$ or the $\mathrm{N}$-methyl-piperidine $9 \mathbf{a}$, showed weak activity in this assay. This is consistent with the loss of activity as the amino group transits from a primary to secondary to tertiary amino group.

Structure-Activity relationships of 1,3,4-oxadiazol-2-thiones-The 4-piperidyl derivative $6 \mathbf{a}$ showed an $\mathrm{IC}_{50}$ comparable to the aminomethyl derivative $\mathbf{6 d}$. This is in contrast to the oxadiazolones where the aminomethyl derivative showed a 40 times lower $\mathrm{IC}_{50}$ than the 4-piperidyl derivative. The aminoethyl derivative $\mathbf{6 g}$ showed the third highest degree of inhibition in the thione series. However, when the aminomethyl or aminoethyl was bridged in the thione series to obtain a 2-pyrrolidinyl $6 \mathbf{c}$ or 3-piperidinyl 6 b compound a significant amount of affinity was still retained. This is also different from the oxadiazolones where the corresponding modifications were not tolerated. Another difference was found when comparing the primary, secondary and tertiary aminomethyl compounds. Here the primary 
aminomethyl $\mathbf{6 d}$ had a higher affinity than the dimethylaminomethyl compound 10c which in turn had a higher affinity than the methylaminomethyl compound $\mathbf{6 e}$. This decline in affinity seems to be correlated to the basicity. We infer that the amine-N interacts with the protein. Other side chains that resulted in a weak affinity are the compounds with the 4-(N-methylpiperidinyl) 10a and the 4-(N-benzyl-piperidinyl) 10b moiety. Again the cyclohexyl- and methyl substituted oxadiazol-2-thiones 10d and 10e did not show a significant inhibition of muscimol binding.

\section{Structure-activity relationships of modifications to the 1,3,4-oxadiazol-2-one} ring itself-As mentioned above, substituting the 2-one oxygen with sulfur did not have a uniform effect. Depending on the amine-side chain in position 5 of the heterocycle the sulfur bearing compound exhibited lower (4-piperidinyl, $\mathbf{6 a}<\mathbf{5 a}$; 3-piperidinyl, $\mathbf{6} \mathbf{b}<\mathbf{5 b} ; 2$ pyrrolidinyl, $\mathbf{6 c}<\mathbf{5 c}$ ) or higher $\mathrm{IC}_{50}$ values (aminomethyl, $\mathbf{6 d}>\mathbf{5 d}$; 2 -aminoethyl, $\mathbf{6 g}>\mathbf{5 g}$; methylaminomethyl, $\mathbf{6 e}>\mathbf{5 e}$ ) than their oxygen bearing counterparts. For other side chains there was no difference in affinity detected between -thione and -one (N-methyl-piperidine, $9 \mathbf{a}=10 \mathbf{a} ;$ N-benzyl-piperidine, $9 \mathbf{b}=\mathbf{1 0 b}$ ). The 4-piperidinyl series 5a, 6a, 19 showed, that the hydrogens of the oxadiazol-2-one/oxadiazol-2-thione 3-nitrogen or of the tautomeric oxadiazol-2-ol/oxadiazol-2-thiol 2-alcohol/2 thioalcohol oxygen/sulfur are unlikely to be directly involved in hydrogen-bonding, nor, in their deprotonated form, in ion-ion or ion- $\pi$ interactions, since the 2-methyl-1,3,4-oxadiazole showed intermediate affinity. Moreover, we infer that the heteroatoms in the 1,3,4-oxadiazol ring act as hydrogen-bond acceptors when interacting with amino acids in the binding site. However, the drop in affinity from $\mathbf{6 a}$ over $\mathbf{1 9}$ to $\mathbf{5} \mathbf{a}$ followed the decrease in volume of the 2-substituent of the 1,3,4-oxadiazol (sulfur > $\mathrm{CH}_{3}>$ oxygen). The compound with the smallest substituent (hydrogen) at position 2 of the 1,3,4-oxadiazol 11 showed a complete loss of affinity opposite to the derivatives with an oxygen $\mathbf{9 b}$ or sulfur $\mathbf{1 0 b}$, again indicating that some bulk at the 2-position is necessary.

The 1,2,4-triazoles explore the effect of substituting the oxygen at position 1 of the 1,3,4oxadiazol-ones/thiones with a benzyl substituted nitrogen. This exchange was not tolerated at all in the aminomethyl compound: the triazole 16d completely lost its affinity in contrast to the 1,3,4-oxadiazol-2-one, whereas the 4-piperidinyl triazole 16a showed a reduced but still significant displacement of $\left[{ }^{3} \mathrm{H}\right]$ muscimol. The difference in tolerance of bulk at this position of the heterocyclic half of the compounds might indicate that the longer piperidine derivatives share the binding partners for the side chain amino- $\mathrm{N}$ with the shorter ligands, but bridge to different amino acids of the binding site with the heterocyclic portion of the molecule. This difference in coordination might account for the difference in tolerance for bulky substituents.

Comparison with previous 4-PIOL derivatives-Frølund and colleagues have reported on the synthesis and evaluation of 4-PIOL derivatives as GABA partial agonists or antagonists. They mainly investigated the influence of substituents at position 4 of the 3-isoxazolol ring 39,54 . In these studies, small aliphatic and also bulky aromatic substituents were tolerated. 4-PIOL derivatives in these investigations had a $\mathrm{K}_{\mathrm{i}}$ between 0.049 and $10 \mu \mathrm{M}$ as compared to 4-PIOL with $9.1 \mu \mathrm{M}$ and our best derivatives with an $\mathrm{IC}_{50}$ between 1 and $183 \mu \mathrm{M}$. Methyl or ethyl substitution of 4-PIOL lead to compounds that retained some agonistic activity with the binding affinity as determined by $\left[{ }^{3} \mathrm{H}\right]$ muscimol binding assays being retained as well, whereas the bulky substituents did not show agonistic activity but their affinity was increased in the binding assays. In the context of the 1,3,4-oxadiazol-2-ol moiety used in the present study, substitution of the oxygen at position 1 with a benzyl substituted nitrogen did not improve affinity as 16a had a somewhat lower affinity than $\mathbf{5 a}$. We infer that the large cavity that has been suggested to accommodate the aromatic residues of the 4-subsituted 4-PIOL derivatives, is not available for compounds of our series, possibly because the 1,3,4-triazol-2-ol derivatives are not arranged in a way that would align the aromatic moiety with the hydrophobic pocket. It is likely that the occupancy of this cavity by the aromatic substituted 4-PIOL derivatives 
prevents the binding site closure which has been proposed to be an early step in the conformational change linking ligand binding to channel gating.

It has been observed previously that the exchange of an oxygen in the small carboxyl group bioisosteric ring by a sulfur can have different effects: the sulfur analogue of 4-PIOL has a higher affinity than 4-PIOL, whereas the sulfur analogue of THIP has a lower affinity than the oxygen containing counterpart $40,54,55$. The conclusion was that the 3 -isoxazolol heterocycles of 4-PIOL and THIP are not at identical positions in the binding sites. Further results demonstrated that the flexible side chain of the arginine R66 in the $\alpha_{1}$ subunit might enable the binding pocket to adapt to different bioactive conformations of ligands 54 .

a-subunit specificity-The electrophysiological characterization of the most active compounds was divided in investigating the agonistic potency of individual compounds and determining their modulating effect on GABA-induced currents. The agonistic profiling yielded $\mathbf{5 d}$ as the most active compound. This compound had an $\mathrm{EC}_{50}$ comparable to the GABA $\mathrm{EC}_{50}$ at all $\alpha_{1-6} \beta_{3} \gamma_{2}$ subunit combinations, ranging between from $30 \mu \mathrm{M}$ for $\alpha_{6}$ to $1 \mathrm{mM}$ for $\alpha_{3}$-containing receptors. In the GABA current modulating assay $\mathbf{5 d}$ showed potentiating effects at all subunit combinations reflecting its pure agonistic character. We assume that the small $\mathbf{5 d}$ compound can be accommodated in all binding sites irrespective of the specific $\alpha$ subunit where its orientation and size allow complete agonist-induced contraction of the binding site and subsequent gating in a manner comparable to the GABA induced effect. Increasing the spacer that bridges the basic amino function from the oxadiazolol moiety from a methylene group in $\mathbf{5 d}$ to a piperidine ring in $\mathbf{5 a}$ converts the compound from an unselective agonist into an antagonist at $\alpha_{1}, \alpha_{4}$, and $\alpha_{6}$ containing receptors and a weak partial agonist at $\alpha_{2}, \alpha_{3}$ and $\alpha_{5}$ containing receptors. The intrinsic activity is highest at $\alpha_{5}$ containing receptors. The thio derivative of 5a, 6a, showed a comparable profile, with the exception that at $\alpha_{2}$ containing receptors it is potentiating GABA currents at low concentrations while it is inhibitory at higher concentrations. The methyl derivative $\mathbf{1 9}$ was only agonistic at $\alpha_{6}$ receptors, while it showed slight potentiating effects at high concentrations at $\alpha_{2}, \alpha_{4}, \alpha_{5}$ and $\alpha_{6}$ containing receptors.

6a binds in the GABA binding site-Numerous drugs modulate and directly activate $\mathrm{GABA}_{\mathrm{A}}$ receptors often by binding to sites other than the GABA binding sites. Based on several lines of evidence we conclude that 6a binds within the GABA binding pocket. First, 6a protected $\alpha_{1}$ F64C and $\alpha_{1}$ S68C from modification by MTSES $^{-}$(Fig. 7 and 8). These residues are located in the GABA binding site in a homology model based on the AChBP structure $49,56-58$. Czajkowski and coworkers previously showed that GABA protected the cysteine at $\alpha_{1}$ F64C from modification by MTSES $^{-}$but pentobarbital did not. Pentobarbital activates the receptor by binding at a site in the transmembrane domain. Thus, the lack of protection by pentobarbital argues that the protection induced by GABA is due to local steric effects of GABA and not due to conformational changes associated with gating 46,47 . Thus, we conclude that 6a protected $\alpha_{1} \mathrm{~F} 64 \mathrm{C}$ by its presence in the GABA binding site and not by conformational changes induced by $\mathbf{6 a}$ binding. Secondly, $\mathbf{6 a}$ specifically and covalently modified the neighboring cysteine-substitution mutant, $\alpha_{1}$ R66C, inhibiting the subsequent GABA currents. This inhibition did not occur with $\mathbf{5 a}$ which has an oxygen in place of the thiol-reactive sulfur in 6a. Furthermore, following inhibition of $\alpha_{1}$ R66 $\mathrm{C}$ by reaction with $\mathbf{6 a}$ subsequent application of MTSES ${ }^{-}$had no effect, whereas, without $\mathbf{6 a}$ pretreatment, application of MTSES $^{-}$would have inhibited the GABA-induced currents. Thus, MTSES $^{-}$had no effect when it was applied after $6 \mathbf{a}$ because $\mathrm{MTSES}^{-}$cannot react with disulfide linked sulfurs. In contrast, the inhibition induced by $6 \mathbf{a}$ reaction was reversed by DTT application indicating that $\mathbf{6 a}$ formed a mixed disulfide bond with the cysteine thiol. Taken together, we infer that 6a binds in the GABA binding site. 
The ability of $6 \mathbf{a}$ to protect $\alpha_{1}$ S68C from modification by MTSES $^{-}$provides insight into the conformational changes induced by $\mathbf{6 a}$ binding (Fig. 8). Both GABA and pentobarbital protected this cysteine mutant from MTSES $^{-}$modification. Czajkowski and coworkers concluded that in the activated state conformation, access to this residue was reduced due to a conformational change of the binding site rather than by the presence of GABA in the binding site ${ }^{59}$. We infer that in the region of $\alpha_{1}$ S68 $\mathbf{6 a}$ produces a similar conformational change to that induced by GABA and pentobarbital when it activates the receptor. This suggests that 6a induces a conformational change in the receptor similar to that induced by GABA binding.

Further, the disulfide bond formation between 6a and the introduced cysteine at the $\alpha_{1}$ R66 position provides insight into the orientation of $\mathbf{6 a}$ in the GABA binding site. The reaction between 6a and $\alpha_{1}$ R66C appears to be specific because 6a did not react at a measurable rate with the cysteine substituted for the neighboring residues on the same $\beta$ strand, $\alpha_{1} \mathrm{~F} 64$ or $\alpha_{1} \mathrm{~S} 68$, nor did it react with a cysteine at $\alpha_{1} \mathrm{~T} 129$, the residue predicted to lie in closest proximity on the adjacent $\beta$ strand. If all other factors were similar, the ratio of the reaction rates of $\mathbf{6 a}$ with the four cysteine mutants should be similar to the ratio of the reaction rates for the MTS reagents with these mutants. The MTS reagents reacted faster with $\alpha_{1} \mathrm{~F} 64 \mathrm{C}$ and $\alpha_{1} \mathrm{~S} 68 \mathrm{C}$ than with $\alpha_{1} \mathrm{R} 66 \mathrm{C}$ (Table 6). Thus, it is surprising that 6a only reacted at a measurable rate with $\alpha_{1}$ R66C. Since 6a is much less reactive than the MTS reagents the reason why this compound only reacts at this position must be attributed to a highly selective interaction of the 6a sulfur with the $\alpha_{1}$ R66C sulfur. Therefore, we infer that the favorable orientation of $\mathbf{6 a}$ in the binding site brings the 6a sulfur into close proximity with the $\alpha_{1}$ R66 position leading to the highly specific reaction. This establishes one point of contact between $\mathbf{6 a}$ and the complementary side of the binding site.

We assume that 6a bridges the principle and complementary sides of the binding site in a manner similar to GABA. We generated a model of the GABA $\mathrm{A}_{\mathrm{A}}$ receptor $\beta_{2^{-}} \alpha_{1}$ interface based on the AChBP crystal structure with nicotine bound (Figure 10). 6a can fit into the binding site with its basic nitrogen superposed on the position of nicotine's basic pyridine nitrogen in the principle side of the binding site and with the $\mathbf{6 a}$ sulfur in close proximity to the introduced $\alpha_{1} 66 \mathrm{C}$ sulfur on the complementary side of the binding site (Figure 10B). The close proximity of the sulfurs may explain the high collision probability and consequently the reactivity necessary to form the disulfide bond between $\mathbf{6 a}$ and the engineered cysteine at position $\alpha_{1}$ R66. This orientation in the binding site may explain why it is a weak agonist. In the AChBP crystal structure on the complementary side of the binding site, nicotine forms hydrogen bonds with backbone carbonyls and amides on the $\beta$ strand containing the residue that aligns with $\alpha_{1}$ T129 (Figure 10C). This $\beta$ strand is adjacent to the $\alpha_{1}$ R66-containing $\beta$ strand. 6a is larger than GABA: the distance between the two potential H-bonding sites, i.e., the protonated positively charged nitrogen and the most distant high electron dense heteroatom $\mathrm{O}$ (GABA) and S (6a) (Figure 11 and 10), being $6.1 \AA$ and $7.6 \AA$, respectively. Thus, GABA might only span the distance between the $\beta$-subunit principle site residues where the positively charged $\mathrm{N}$ is coordinated and the $\alpha_{1}$ T129 $\beta$-strand of loop E (Figure 10A). In contrast, the larger $\mathbf{6 a}$ extends to the more distant $\beta$ strand containing residue $\alpha_{1}$ R66 (Figure 10B). Activation of the Cys-loop receptors may involve a contraction of the two halves of the binding site ${ }^{59}$. Because $6 \mathbf{a}$ bridges to a different part of the complementary side of the binding site its ability to pull the two halves of the binding site together may be reduced compared to GABA resulting in $6 \mathbf{a}$ being a partial agonist. The idea that $\mathbf{6 a}$ is a partial agonist because it is less effective at closing the binding site is consistent with the conceptual model of partial agonism derived from structural studies of the ionotropic glutamate receptors 60 .

6a should not cover the $\alpha_{1}$ loop connecting L117 and L127 that harbors the four amino acids (ITED in $\alpha_{1}$ ) recently identified as $\alpha$ variant specific transducing elements rather than binding site elements ${ }^{4}$. A trap-like motion of this loop, to an extent specified by these four amino acids 
in a given $\alpha$ isoform, could further explain the differences in GABA sensitivities between the $\mathrm{GABA}_{\mathrm{A}}$ receptor subtypes.

\section{Conclusions}

We synthesized a series of derivatives of 4-PIOL, a compound previously shown to be a weak $\mathrm{GABA}_{\mathrm{A}}$ partial agonist. We started by replacing the 3-isoxazolol moiety in 4-PIOL with a 1,3,5-oxadiazol-2-ol moiety to yield 5a. For the first time we describe $\mathrm{GABA}_{\mathrm{A}}$ receptor ligands with a 1,3,5-oxadiazol-2-ol as a carboxylic acid bio-isosteric group. Compound 5a was modified at different positions to investigate structure-activity relationships: the piperidine moiety was exchanged and modified, the substituent at the 2 position of the 1,3,5-oxadiazol-2ol was varied, and the 1,3,5-oxadiazol-2-ol was exchanged by 1,2,4-triazol-5-ol.

The most active piperidine derivatives $5 \mathbf{a}$ and $\mathbf{6 a}$ were weak partial agonists that differentiated weakly between different $\alpha$ subunit containing receptors, whereas the small aminomethyl $\mathbf{5 d}$ showed a profile of a pure agonist that is very similar to GABA.

The described structure-activity relationships extend the currently available information for ligands of the agonist binding site of the $\mathrm{GABA}_{\mathrm{A}}$ receptor. Frølund et al. have shown previously how to convert 4-PIOL into pure antagonistic compounds while we now show how 4-PIOL can be modified to either obtain a pure or partial agonists with weak $\alpha$ subtype preferring profiles.

In addition, this study demonstrates that $\mathbf{6 a}$ binds in the GABA binding site, and that $\mathbf{6 a}$ is oriented in the binding site such that its interaction with the complementary portion of the binding site is displaced from the interaction site of nicotine and carbamylcholine in the AChBP structure. The later finding may explain why $\mathbf{6 a}$ is a partial agonist. Further investigations are necessary to determine if the two GABA binding sites are the only sites involved in the activity of this compound. These results coupled with GABA binding site homology models based on the AChBP structure may provide a foundation for rational design of $\mathrm{GABA}_{\mathrm{A}}$ receptor subtypespecific agonists with higher efficacy and specificity.

\section{Experimental Section}

\section{Chemistry}

Procedures and spectroscopic data for non-target compounds can be found in the supporting information.

General Procedures for the Removal of the Boc-group: Procedure $F$ (Compounds 5a,c,e,f,g, 6c,d,e,f,g, 16a,d, 17a, 19)—The Boc-protected amine (1 equiv) was dissolved in a minimum amount of methanol and cooled in an ice-bath in a nitrogen atmosphere. After adding ethanolic $\mathrm{HCl} 2.3 \mathrm{~N}$ (4.5 equiv) the mixture was allowed to reach room temperature and stirred overnight. Products were isolated by filtration in a nitrogen atmosphere, in some cases a precipitate was only formed after adding ethyl acetate (50-98\%).

Procedure G (Compounds 5b,d, 6a,b, 19)-The Boc-protected amine was dissolved in ethyl acetate and cooled to $-20^{\circ} \mathrm{C}$ in a nitrogen atmosphere. Gaseous $\mathrm{HCl}$ was bubbled through the mixture for $5 \mathrm{~min}$. The reaction was allowed to come to room temperature and stirred until a precipitate was formed. Products were isolated by filtration in a nitrogen atmosphere, or after removing the solvent and recrystallization in ethanol (56-88\%).

5-Piperidin-4-yl-3H-[1,3,4]oxadiazol-2-one Hydrochloride. (5a)-Starting from 3a the compound was synthesized as described in procedure F: white crystals $(98 \%) ; \mathrm{mp}=314^{\circ}$ 
C; ${ }^{1} \mathrm{H}$ NMR (DMSO-d $\left.{ }_{6}\right) \delta 1.74-1.88(\mathrm{~m}, 2 \mathrm{H}, 2 \mathrm{CH}), 2.00-2.05(\mathrm{~m}, 2 \mathrm{H}, 2 \mathrm{CH}), 2.89-3.03(\mathrm{~m}$, $3 \mathrm{H}, 3 \mathrm{CH}), 3.21-3.25$ (m, 2H, 2CH), 8.98-9.28 (m, 2H, NH$), 12.26$ (s, 1H, NH); ${ }^{13} \mathrm{C} \mathrm{NMR}$ $\left(\right.$ DMSO-d $\left._{6}\right) \delta 24.75\left(\mathrm{CH}_{2}\right), 30.94(\mathrm{CH}), 42.07\left(\mathrm{CH}_{2}\right), 155.11(\mathrm{Cq}), 158.08(\mathrm{Cq})$; EI-MS $\mathrm{m} / 2$ $169\left(\mathrm{M}^{+}\right)$. Anal. $\left(\mathrm{C}_{7} \mathrm{H}_{11} \mathrm{~N}_{3} \mathrm{O}_{2} \cdot \mathrm{HCl}\right) \mathrm{C}, \mathrm{H}, \mathrm{N}$.

5-Piperidin-3-yl-3H-[1,3,4] oxadiazol-2-one Hydrochloride. (5b)-Starting from $3 \mathrm{~b}$ the compound was synthesized as described in procedure G. The solvent was removed under reduced pressure and the residue recrystallized from ethanol: white crystals $(66 \%) ; \mathrm{mp}=207$ ${ }^{\circ} \mathrm{C} ;{ }^{1} \mathrm{H}$ NMR (DMSO-d $\left.{ }_{6}\right) \delta 1.60-1.85(\mathrm{~m}, 3 \mathrm{H}, 3 \mathrm{CH}), 1.97-2.01(\mathrm{~m}, 1 \mathrm{H}, 1 \mathrm{CH}), 2.82-2.91(\mathrm{~m}$, $1 \mathrm{H}, 1 \mathrm{CH}), 2.96-3.04(\mathrm{~m}, 1 \mathrm{H}, 1 \mathrm{CH}), 3.13-3.19(\mathrm{~m}, 2 \mathrm{H}, 2 \mathrm{CH}), 9.26\left(\mathrm{~m}, 2 \mathrm{H}, \mathrm{NH}_{2}\right), 12.32(\mathrm{~s}$, $1 \mathrm{H}, \mathrm{NH}) ;{ }^{13} \mathrm{C} \mathrm{NMR}\left(\mathrm{DMSO}_{6}\right) \delta 24.75\left(\mathrm{CH}_{2}\right), 30.94(\mathrm{CH}), 42.07\left(\mathrm{CH}_{2}\right), 155.11(\mathrm{Cq}), 158.08$ (Cq); MS m/z $167\left(\mathrm{M}^{+}-2\right.$ free base). Anal. $\left(\mathrm{C}_{7} \mathrm{H}_{11} \mathrm{~N}_{3} \mathrm{O}_{2} \cdot \mathrm{HCl}\right) \mathrm{C}, \mathrm{H}, \mathrm{N}$.

L-5-Pyrrolidin-2-yl-3H-[1,3,4]oxadiazol-2-one Hydrochloride. (5c)—Starting from $3 \mathbf{c}$ the compound was synthesized as described in procedure $\mathrm{F}$ : white crystals $(84 \%) ; \mathrm{mp}=199$ ${ }^{\circ} \mathrm{C} ;{ }^{1} \mathrm{H}$ NMR (DMSO-d $\mathrm{d}_{6}$ ) $\delta 1.88-2.05$ (m, 2H, 2CH), 2.12-2.30 (m, 2H, 2CH), 3.20-2.25 (m, $2 \mathrm{H}, \mathrm{CH}), 4.63(\mathrm{t}, 7.75 \mathrm{~Hz}, 1 \mathrm{H}, \mathrm{CH}), 10.13\left(\mathrm{~s}, 2 \mathrm{H}, \mathrm{NH}_{2}\right), 12.72(\mathrm{~s}, 1 \mathrm{H}, \mathrm{NH}) ;{ }^{13} \mathrm{C}$ NMR (DMSO$\left.\mathrm{d}_{6}\right) \delta 23.77\left(\mathrm{CH}_{2}\right), 27.18\left(\mathrm{CH}_{2}\right), 45.56\left(\mathrm{CH}_{2}\right), 52.88(\mathrm{CH}), 152.34(\mathrm{Cq}), 154.72(\mathrm{Cq})$; EI-MS $m / z 155\left(\mathrm{M}^{+}\right.$free base $) ;[\alpha]^{\mathrm{D}}=-3.9^{\circ}\left(\mathrm{RT}, \mathrm{c}=0.71, \mathrm{H}_{2} \mathrm{O}\right)$. Anal. $\left(\mathrm{C}_{6} \mathrm{H}_{9} \mathrm{~N}_{3} \mathrm{O}_{2} \cdot \mathrm{HCl}\right) \mathrm{C}, \mathrm{H}, \mathrm{N}$.

5-Aminomethyl-3H-[1,3,4]oxadiazol-2-one Hydrochloride. (5d)—Starting from 3d the compound was synthesized as described in procedure $\mathrm{G}$. The product was separated by filtration after stirring a few minutes at room temperature: white crystals $(88 \%) ; \mathrm{mp}=235^{\circ}$ $\mathrm{C} ;{ }^{1} \mathrm{H}$ NMR $\left(\mathrm{DMSO}_{6} \mathrm{~d}_{6}\right) \delta 4.03\left(\mathrm{~s}, 2 \mathrm{H}, \mathrm{CH}_{2}\right), 8.82\left(\mathrm{~s}, 3 \mathrm{H}, \mathrm{CH}_{2} \mathrm{NH}_{3}\right), 12.71$ (s, $\left.1 \mathrm{H}, \mathrm{NH}\right)$; EIMS $m / z 115\left(\mathrm{M}^{+}\right.$free base). Anal. $\left(\mathrm{C}_{3} \mathrm{H}_{5} \mathrm{~N}_{3} \mathrm{O}_{2} \cdot \mathrm{HCl}\right) \mathrm{C}, \mathrm{H}, \mathrm{N}$.

5-Methylaminomethyl-3H-[1,3,4]oxadiazol-2-one Hydrochloride (5e)-Starting from $3 \mathbf{e}$ the compound was synthesized as described in procedure $\mathrm{F}$ : white crystals (79\%); $\mathrm{mp}$ $=176{ }^{\circ} \mathrm{C} ;{ }^{1} \mathrm{H}$ NMR $\left(\right.$ DMSO-d $\left._{6}\right) \delta 2.58\left(\mathrm{~s}, 3 \mathrm{H}, \mathrm{CH}_{3}\right), 4.15\left(\mathrm{~s}, 2 \mathrm{H}, \mathrm{CH}_{2}\right), 9.88\left(\mathrm{~s}, 2 \mathrm{H}, \mathrm{NH}_{2}\right)$, $12.81(\mathrm{~s}, 1 \mathrm{H}, \mathrm{NH}) ;{ }^{13} \mathrm{C}$ NMR $\left(\mathrm{DMSO}-\mathrm{d}_{6}\right) \delta 32.75\left(\mathrm{CH}_{2}\right), 42.22\left(\mathrm{CH}_{3}\right), 150.10(\mathrm{Cq}), 154.65$ (Cq); EI-MS m/z 129 ( $\mathrm{M}^{+}$free base). Anal. $\left(\mathrm{C}_{4} \mathrm{H}_{7} \mathrm{~N}_{3} \mathrm{O}_{2} \cdot \mathrm{HCl}\right) \mathrm{C}, \mathrm{H}, \mathrm{N}$.

D-5-(1-Amino-ethyl)-3H-[1,3,4]oxadiazol-2-one Hydrochloride. (5f)—Starting from 3 f the compound was synthesized as described in procedure $\mathrm{F}$ : white crystals $(90 \%) ; \mathrm{mp}=194$ ${ }^{\circ} \mathrm{C} ;{ }^{1} \mathrm{H}$ NMR (DMSO-d $\left.{ }_{6}\right) \delta 1.47\left(\mathrm{~d}, 6.86 \mathrm{~Hz}, 3 \mathrm{H}, \mathrm{CH}_{3}\right), 4.44(\mathrm{q}, 6.86 \mathrm{~Hz}, 1 \mathrm{H}, \mathrm{CH}), 8.93(2$, $\left.3 \mathrm{H}, \mathrm{NH}_{3}\right), 12.75(\mathrm{~s}, 1 \mathrm{H}, \mathrm{NH}) ;{ }^{13} \mathrm{C}$ NMR $\left(\mathrm{DMSO}-\mathrm{d}_{6}\right) \delta 15.77\left(\mathrm{CH}_{3}\right), 42.62\left(\mathrm{CH}_{2}\right), 154.16(\mathrm{Cq})$, $154.67(\mathrm{Cq})$; EI-MS $m / z 129\left(\mathrm{M}^{+}\right.$free base); $[\alpha]^{\mathrm{D}}=+7.0^{\circ}\left(\mathrm{RT}, \mathrm{c}=0.63, \mathrm{H}_{2} \mathrm{O}\right)$. Anal. $\left(\mathrm{C}_{4} \mathrm{H}_{7} \mathrm{~N}_{3} \mathrm{O}_{2} \cdot \mathrm{HCl}\right) \mathrm{C}, \mathrm{H}, \mathrm{N}$.

[5-(2-Amino-ethyl)-3H-[1,3,4]oxadiazol-2-one Hydrochloride. (5g)—Starting from $3 \mathbf{g}$ the compound was synthesized as described in procedure $\mathrm{F}$ : white crystals $(77 \%) ; \mathrm{mp}=$ $206{ }^{\circ} \mathrm{C} ;{ }^{1} \mathrm{H}$ NMR (DMSO-d 6 ) $\delta 2.89\left(\mathrm{t}, 6.60 \mathrm{~Hz}, 2 \mathrm{H}, \mathrm{CH}_{2} \mathrm{CH}_{2} \mathrm{NH}_{3}\right), 3.06(\mathrm{t}, 6.74 \mathrm{~Hz}, 1 \mathrm{H}$, $\left.\mathrm{CH}_{2} \mathrm{CH}_{2} \mathrm{NH}_{3}\right), 8.23\left(\mathrm{~s}, 3 \mathrm{H}, \mathrm{NH}_{3}\right), 12.25(\mathrm{~s}, 1 \mathrm{H}, \mathrm{NH}) ;{ }^{13} \mathrm{C}$ NMR (DMSO-d 6 ) $\delta 24.49\left(\mathrm{CH}_{2}\right)$, $35.37\left(\mathrm{CH}_{2}\right), 153.97(\mathrm{Cq}), 155.27(\mathrm{Cq})$; EI-MS $m / z .129\left(\mathrm{M}^{+}\right.$free base). Anal. $\left(\mathrm{C}_{4} \mathrm{H}_{7} \mathrm{~N}_{3} \mathrm{O}_{2} \cdot \mathrm{HCl}\right) \mathrm{C}, \mathrm{H}, \mathrm{N}$.

5-Piperidin-4-yl-3H-[1,3,4]oxadiazol-2-thione Hydrochloride. (6a)-Starting from 4a the compound was synthesized as described in procedure $\mathrm{G}(74 \%)$. The compound was also synthesized following procedure $F$. In this case $1 / 3$ of methanol co-crystallized with $\mathbf{6 a}$, which could be removed by solving the crystals in water, removing some of the solvent under vacuum at $20{ }^{\circ} \mathrm{C}$ and freeze drying the resulting solution (91\%): white crystals; $\mathrm{mp}=232{ }^{\circ} \mathrm{C} ;{ }^{1} \mathrm{H}$ NMR $\left(\right.$ DMSO-d $\left._{6}\right) \delta 1.79-1.92(\mathrm{~m}, 2 \mathrm{H}, 2 \mathrm{CH}), 2.06-2.12(\mathrm{~m}, 2 \mathrm{H}, 2 \mathrm{CH}), 2.90-3.07$ (m, 2H, 2CH), 
3.15-3.28 (m, 3H, 3CH), 8.89-9.19 (m, 2H, NH $), 14.49$ (s, 1H, NH); ${ }^{13} \mathrm{C}$ NMR (DMSO-d 6 ) $\delta 24.96\left(\mathrm{CH}_{2}\right), 30.50(\mathrm{CH}), 42.01\left(\mathrm{CH}_{2}\right), 165.04(\mathrm{Cq}), 177.93(\mathrm{Cq})$; EI-MS $m / z 185\left(\mathrm{M}^{+}\right.$free base). Anal. $\left(\mathrm{C}_{7} \mathrm{H}_{11} \mathrm{~N}_{3} \mathrm{OS} \cdot \mathrm{HCl}\right) \mathrm{C}, \mathrm{H}, \mathrm{N}, \mathrm{S}$.

5-Piperidin-3-yl-3H-[1,3,4]oxadiazol-2-thione Hydrochloride. (6b)-Starting from 4b the compound was synthesized as described in procedure $\mathrm{G}$, with the exception that $10 \%$ of the solvent were ethanol. The solvent was removed under reduced pressure and the residue recrystallized in ethanol: slightly green crystals $(58 \%) ; \mathrm{mp}=219{ }^{\circ} \mathrm{C} ;{ }^{1} \mathrm{H}$ NMR $\left(\right.$ DMSO-d $\left.{ }_{6}\right) \delta$ 1.70-1.85 (m, 3H, 3CH), 2.00-2.10 (m, 1H, CH), 2.80-2,92 (m, 1H, CH), 3.04-3.19 (m, $2 \mathrm{H}$, 2CH), 3.34-3.43 (m, 2H, CH), 9.20-9.60 (m, 2H, NH $)$, 14.55 (s, 1H, NH); ${ }^{13} \mathrm{C}$ NMR (DMSO$\left.\mathrm{d}_{6}\right) \delta 20.75\left(\mathrm{CH}_{2}\right), 24.88\left(\mathrm{CH}_{2}\right), 30.82(\mathrm{CH}), 43.02\left(\mathrm{CH}_{2}\right), 44.01\left(\mathrm{CH}_{2}\right), 163.08(\mathrm{Cq}), 177.94$ (Cq); EI-MS m/z 185 ( $\mathrm{M}^{+}$free base). Anal. $\left(\mathrm{C}_{7} \mathrm{H}_{11} \mathrm{~N}_{3} \mathrm{OS} \cdot \mathrm{HCl} \cdot 1 / 3 \mathrm{H}_{2} \mathrm{O}\right) \mathrm{C}, \mathrm{H}, \mathrm{N}, \mathrm{S}$.

L-5-Pyrrolidin-2-yl-3H-[1,3,4]oxadiazol-2-thione Hydrochloride. (6c)-Starting from $\mathbf{4 c}$ the compound was synthesized as described in procedure $\mathrm{F}$ : white crystals $(50 \%) ; \mathrm{mp}$ $=167{ }^{\circ} \mathrm{C} ;{ }^{1} \mathrm{H}$ NMR $\left(\right.$ DMSO- $\left._{6}\right) \delta 1.91-2.08(\mathrm{~m}, 2 \mathrm{H}, 2 \mathrm{CH}), 2.15-2.36(\mathrm{~m}, 2 \mathrm{H}, 2 \mathrm{CH}), 3.26(\mathrm{app}$ t, $6.44 \mathrm{~Hz}, 2 \mathrm{H}, 2 \mathrm{CH}$ ), 4.80 (app t, $7.23 \mathrm{~Hz}, 2 \mathrm{H}, 2 \mathrm{CH}), 10.15$ (s, 1H, NH); ${ }^{13} \mathrm{C}$ NMR (DMSO$\left.\mathrm{d}_{6}\right) \delta 23.79\left(\mathrm{CH}_{2}\right), 27.73\left(\mathrm{CH}_{2}\right), 45.71\left(\mathrm{CH}_{2}\right), 52.13(\mathrm{CH}), 159.25(\mathrm{Cq}), 178.38(\mathrm{Cq})$; EI-MS $m / z 171\left(\mathrm{M}^{+}\right.$free base $\left.) ; \alpha\right]^{\mathrm{D}}=-0.14^{\circ}\left(\mathrm{RT}, \mathrm{c}=0.58, \mathrm{H}_{2} \mathrm{O}\right)$. Anal. $\left(\mathrm{C}_{6} \mathrm{H}_{9} \mathrm{~N}_{3} \mathrm{OS} \cdot \mathrm{HCl} \cdot 1 / 3 \mathrm{H}_{2} \mathrm{O}\right)$ $\mathrm{C}, \mathrm{H}, \mathrm{N}, \mathrm{S}$.

5-Aminomethyl-3H-[1,3,4]oxadiazol-2-thione Hydrochloride. (6d)-Starting from 4d the compound was synthesized as described in procedure $\mathrm{F}$ : beige crystals $(71 \%) ; \mathrm{mp}=$ $184{ }^{\circ} \mathrm{C} ;{ }^{1} \mathrm{H}$ NMR (DMSO-d 6 ) $\delta 4.21\left(\mathrm{~s}, 2 \mathrm{H}, \mathrm{CH}_{2}\right), 8.93\left(\mathrm{~s}, 3 \mathrm{H}, \mathrm{NH}_{3}\right), 14.83(\mathrm{~s}, 1 \mathrm{H}, \mathrm{NH}) ;{ }^{13} \mathrm{C}$ NMR (DMSO-d 6 ) $\delta 33.56\left(\mathrm{CH}_{2}\right), 158.27(\mathrm{Cq}), 178.21(\mathrm{Cq})$; EI-MS m/z 131. Anal.

$\left(\mathrm{C}_{3} \mathrm{H}_{5} \mathrm{~N}_{3} \mathrm{OS} \cdot \mathrm{HCl}\right) \mathrm{C}, \mathrm{H}, \mathrm{N}, \mathrm{S}$.

5-Methylaminomethyl-3H-[1,3,4]oxadiazol-2-thione Hydrochloride. (6e)—Starting from $\mathbf{4 e}$ the compound was synthesized as described in procedure $\mathrm{F}$ : white crystals (81\%); $\mathrm{mp}$ $=158{ }^{\circ} \mathrm{C} ;{ }^{1} \mathrm{H}$ NMR $\left(\right.$ DMSO-d $\left._{6}\right) \delta 2.61\left(\mathrm{~s}, 3 \mathrm{H}, \mathrm{CH}_{3}\right), 4.35\left(\mathrm{~s}, 2 \mathrm{H}, \mathrm{CH}_{2}\right), 9.99(\mathrm{~s}, 1 \mathrm{H}$, $\mathrm{NH}) ;{ }^{13} \mathrm{C}$ NMR $\left(\mathrm{DMSO}_{-}\right) \delta 32.96\left(\mathrm{CH}_{3}\right), 41.51\left(\mathrm{CH}_{2}\right), 156.95(\mathrm{Cq}), 178.22(\mathrm{Cq})$; EI-MS $\mathrm{m} / z, 145(\mathrm{M}+)$. Anal. $\left(\mathrm{C}_{4} \mathrm{H}_{7} \mathrm{~N}_{3} \mathrm{OS} \cdot \mathrm{HCl}\right) \mathrm{C}, \mathrm{H}, \mathrm{N}, \mathrm{S}$.

[5-(2-Amino-ethyl)-3H-[1,3,4]oxadiazol-2-thione Hydrochloride. (6g)—Starting from $\mathbf{4} \mathbf{g}$ the compound was synthesized as described in procedure $\mathrm{F}$ : white crystals (94\%); $\mathrm{mp}$ $=222{ }^{\circ} \mathrm{C} ;{ }^{1} \mathrm{H}$ NMR $\left(\right.$ DMSO-d $\left._{6}\right) \delta 3.06-3.14\left(\mathrm{~m}, 4 \mathrm{H}, \mathrm{CH}_{2} \mathrm{CH}_{2}\right), 8.26\left(\mathrm{~s}, 3 \mathrm{H}, \mathrm{NH}_{3}\right), 14.48(\mathrm{~s}$, $1 \mathrm{H}, \mathrm{NH}) ;{ }^{13} \mathrm{C}$ NMR (DMSO-d 6 ) $\delta 23.85\left(\mathrm{CH}_{2}\right), 35.49\left(\mathrm{CH}_{2}\right), 161.02(\mathrm{Cq}), 178.14(\mathrm{Cq})$; EIMS $m / z, 145$ ( $\mathrm{M}^{+}$free base). Anal. $\left(\mathrm{C}_{4} \mathrm{H}_{7} \mathrm{~N}_{3} \mathrm{OS} \cdot \mathrm{HCl}\right) \mathrm{C}, \mathrm{H}, \mathrm{N}$.

\section{General Procedures for the Synthesis of Oxadiazol-2-ones: Procedure H}

(Compounds 9a-c) - The tertiary amine (2 equiv) was dissolved in $\mathrm{CH}_{2} \mathrm{Cl}_{2}$ and cooled to $0{ }^{\circ} \mathrm{C}$ under a nitrogen atmosphere. After adding a solution of carbonic acid bis(trichloromethyl) carbonate ( 1 equiv) in $\mathrm{CH}_{2} \mathrm{Cl}_{2}$ dropwise the mixture was refluxed. The reaction mixture was evaporated to dryness and the residue recrystallized or chromatographed (20-55\%).

5-(1-Methyl-piperidin-4-yl)-3H-[1,3,4]oxadiazol-2-one. (9a)—Starting from 8a the compound was synthesized as described in procedure $\mathrm{H}$, and recrystallized from methanol: white crystals $(55 \%) ; \mathrm{mp}=281{ }^{\circ} \mathrm{C} ;{ }^{1} \mathrm{H}$ NMR $\left(\right.$ DMSO-d $\left._{6}\right) \delta 1.84-1.98(\mathrm{~m}, 2 \mathrm{H}, 2 \mathrm{CH}), 2.05-$ $2.15(\mathrm{~m}, 2 \mathrm{H}, 2 \mathrm{CH}), 2.69$ (s, 3H, $\left.\mathrm{CH}_{3}\right), 2.84-3.03(\mathrm{~m}, 3 \mathrm{H}, 2 \mathrm{CH}), 3.14-3.44(\mathrm{~m}, 2 \mathrm{H}, 2 \mathrm{CH})$, $10.76(\mathrm{~s}, 1 \mathrm{H}, \mathrm{NH}), 12.25$ (s, 1H, NH); EI-MS $\mathrm{m} / z 183$ ( $\mathrm{M}^{+}$free base). Anal.

$\left(\mathrm{C}_{8} \mathrm{H}_{13} \mathrm{~N}_{3} \mathrm{O}_{2} \cdot \mathrm{HCl} \cdot 1 / 2 \mathrm{H}_{2} \mathrm{O}\right) \mathrm{C}, \mathrm{H}, \mathrm{N}$. 
5-(1-Benzyl-piperidin-4-yl)-3H-[1,3,4]oxadiazol-2-one Hydrochloride. (9b)-

Starting from $\mathbf{8 b}$ the compound was synthesized as described in procedure $\mathrm{H}$, and recrystallized from methanol: white crystals $(55 \%) ; \mathrm{mp}=253{ }^{\circ} \mathrm{C}$; the NMR- and MS-data agreed with literature ${ }^{61}$. Anal. $\left(\mathrm{C}_{14} \mathrm{H}_{17} \mathrm{~N}_{3} \mathrm{O}_{2} \cdot \mathrm{HCl}\right) \mathrm{C}, \mathrm{H}, \mathrm{N}$.

5-Dimethylaminomethyl-3H-[1,3,4]oxadiazol-2-one (9c)-Starting from $8 \mathrm{c}$ the compound was synthesized as described in procedure $\mathrm{H}$. The mixture was poured onto water and extracted with ethyl acetate at $\mathrm{pH}$ 7. The combined organic extracts were dried $\left(\mathrm{Na}_{2} \mathrm{SO}_{4}\right)$, the solvent was removed under vacuo and the residue chromatographed with ethyl acetate: white crystals $(20 \%) ; \mathrm{mp}=103{ }^{\circ} \mathrm{C} ; \mathrm{R}_{\mathrm{f}}$ (ethyl acetate): $0.09 ;{ }^{1} \mathrm{H}$ NMR $\left(\right.$ DMSO-d $\left.{ }_{6}\right) \delta$ $2.18\left(\mathrm{~s}, 6 \mathrm{H}, \mathrm{N}\left(\mathrm{CH}_{3}\right)_{2}\right), 3.36\left(\mathrm{~s}, 2 \mathrm{H}, \mathrm{CH}_{2}\right), 12.22(\mathrm{~s}, 1 \mathrm{H}, \mathrm{NH}) ;{ }^{13} \mathrm{C} \mathrm{NMR}\left(\mathrm{DMSO}-\mathrm{d}_{6}\right) \delta 44.72$ $\left(2 \mathrm{CH}_{3}\right), 53.52\left(\mathrm{CH}_{2}\right), 154.76(\mathrm{Cq}), 155.27(\mathrm{Cq})$; EI-MS m/z $143\left(\mathrm{M}^{+}\right)$. Anal. $\left(\mathrm{C}_{5} \mathrm{H}_{9} \mathrm{~N}_{3} \mathrm{O}_{2}\right) \mathrm{C}$, $\mathrm{H}, \mathrm{N}$.

5-Cyclohexyl-3H-[1,3,4]oxadiazole-2-one (9d)—Starting from 8d compound 9d was prepared according to procedure $\mathrm{H}$, and chromatographed: colorless oil which crystallizes on standing $(85 \%) ; \mathrm{mp}=29^{\circ} \mathrm{C}$; IR data agreed with literature ${ }^{62} ; \mathrm{R}_{\mathrm{f}}$ (petroleum ether/ethyl acetate $=2 / 1): 0.5 ;{ }^{1} \mathrm{H}$ NMR $\left(\mathrm{DMSO}_{-} \mathrm{d}_{6}\right) \delta 1.13-1.43(\mathrm{~m}, 5 \mathrm{H}, 5 \mathrm{CH}), 1.58-1.70(\mathrm{~m}, 3 \mathrm{H}, 3 \mathrm{CH}), 1.85-$ $1.88(\mathrm{~m}, 2 \mathrm{H}, 2 \mathrm{CH}), 2.53-2.62(\mathrm{~m}, 1 \mathrm{H}, \mathrm{CH}), 12.03(\mathrm{~s}, 1 \mathrm{H}, \mathrm{NH}) ;{ }^{13} \mathrm{C}$ NMR $\left(\right.$ DMSO-d $\left._{6}\right) \delta 24.45$ $\left(2 \mathrm{CH}_{2}\right), 25.07\left(\mathrm{CH}_{2}\right), 28.45\left(2 \mathrm{CH}_{2}\right), 34.63(\mathrm{CH}), 154.89(\mathrm{Cq}), 159.71(\mathrm{Cq})$; EI-MS m/z 168 $\left(\mathrm{M}^{+}\right)$. Anal. $\left(\mathrm{C}_{8} \mathrm{H}_{12} \mathrm{~N}_{2} \mathrm{O}_{2} \cdot 1 / 5 \mathrm{H}_{2} \mathrm{O}\right) \mathrm{C}, \mathrm{H}, \mathrm{N}$.

5-Methyl-3H-[1,3,4]oxadiazole-2-one (9e)-Starting from $8 \mathrm{e}$ compound $9 \mathrm{e}$ was prepared according to procedure $\mathrm{H}$, and recrystallized from $\mathrm{CH}_{2} \mathrm{Cl}_{2}$ and n-hexane: white crystals (67\%); $\mathrm{mp}=112{ }^{\circ} \mathrm{C}^{63} ;{ }^{13} \mathrm{C}$-NMR-data agreed with literature ${ }^{50} ;{ }^{1} \mathrm{H}$ NMR (DMSO-d 6 ) $\delta 2.18(\mathrm{~s}, 3 \mathrm{H}$, $\left.\mathrm{CH}_{3}\right), 11.99$ (s, $\left.1 \mathrm{H}, \mathrm{NH}\right)$; EI-MS m/z $101\left(\mathrm{M}^{+}+1\right)$. Anal. $\left(\mathrm{C}_{3} \mathrm{H}_{4} \mathrm{~N}_{2} \mathrm{O}_{2}\right) \mathrm{C}, \mathrm{H}, \mathrm{N}$.

5-(1-Methyl-piperidin-4-yl)-3H-[1,3,4]oxadiazole-2-thione (10a)—A mixture of $8 \mathbf{a}$ (1 equiv), pyridine (1.6 ml/equiv) and $\mathrm{CS}_{2}\left(0.2 \mathrm{ml} /\right.$ equiv) was treated at $80-90{ }^{\circ} \mathrm{C}$ until the evolution of $\mathrm{H}_{2} \mathrm{~S}$ had stopped. After removing the solvent under reduced pressure the residue was recrystallized in ethanol and subsequently in methanol. The compound was chromatographed and again recrystallized from methanol: beige crystals $(17 \%) ; \mathrm{mp}=248^{\circ} \mathrm{C}$; $\mathrm{R}_{\mathrm{f}}$ (methanol): $0.5 ;{ }^{1} \mathrm{H}$ NMR (DMSO-d ${ }_{6}$ ) $\delta 1.71-1.84(\mathrm{~m}, 2 \mathrm{H}, 2 \mathrm{CH}), 2.00-2.10(\mathrm{~m}, 2 \mathrm{H}, 2 \mathrm{CH}$ ), $2.61\left(\mathrm{~s}, 3 \mathrm{H}, \mathrm{CH}_{3}\right), 2.75-2.95(\mathrm{~m}, 3 \mathrm{H}, 3 \mathrm{CH}), 3.18-3.27$ (m, 2H, 2CH); ${ }^{13} \mathrm{C}$ NMR (DMSO-d $\mathrm{d}_{6}$ ) $\delta 26.99\left(2 \mathrm{CH}_{2}\right), 30.54(\mathrm{CH}), 43.72\left(\mathrm{CH}_{3}\right), 53.02\left(2 \mathrm{CH}_{2}\right), 164.41(\mathrm{Cq}), 178.93(\mathrm{Cq})$; EI-MS $\mathrm{m} / z, 199\left(\mathrm{M}^{+}\right)$. Anal. $\left(\mathrm{C}_{8} \mathrm{H}_{13} \mathrm{~N}_{3} \mathrm{OS}\right) \mathrm{C}, \mathrm{H}, \mathrm{N}, \mathrm{S}$.

5-(1-Benzyl-piperidin-4-yl)-3H-[1,3,4]oxadiazole-2-thione (10b)—Was synthesized according to the synthesis described for compound 10a, starting from $8 \mathrm{~b}$ : slightly beige crystals $(34 \%) ; \mathrm{mp}=220^{\circ} \mathrm{C} ; \mathrm{R}_{\mathrm{f}}$ (chloroform/methanol $\left.=4 / 1\right): 0.4$; the NMR- and MS-data agreed with literature ${ }^{61}$. Anal. $\left(\mathrm{C}_{14} \mathrm{H}_{17} \mathrm{~N}_{3} \mathrm{OS}\right) \mathrm{C}, \mathrm{H}, \mathrm{N}, \mathrm{S}$.

5-Dimethylaminomethyl-3H-[1,3,4] oxadiazole-2-thione (10c)—Starting from $8 \mathrm{c}$ the compound was synthesized as described in procedure $\mathrm{E}$. The mixture was poured onto water and extracted with ethyl acetate at $\mathrm{pH}$ 7. The combined organic extracts were dried $\left(\mathrm{Na}_{2} \mathrm{SO}_{4}\right)$, the solvent was removed under vacuo and the residue chromatographed: beige crystals $(5 \%) ; \mathrm{mp}=119{ }^{\circ} \mathrm{C} ; \mathrm{R}_{\mathrm{f}}$ (ethyl acetate): $0.08 ;{ }^{1} \mathrm{H} \mathrm{NMR}\left(\mathrm{DMSO}_{-} \mathrm{d}_{6}\right) \delta 7.45(\mathrm{~d}, 1 \mathrm{H}, \mathrm{IndH})$, $2.31\left(\mathrm{~s}, 6 \mathrm{H}, \mathrm{N}\left(\mathrm{CH}_{3}\right)_{2}\right), 3.71\left(\mathrm{~s}, 2 \mathrm{H}, \mathrm{CH}_{2}\right) ;{ }^{13} \mathrm{C} \mathrm{NMR}\left(\mathrm{DMSO}_{6}\right) \delta 44.38\left(\mathrm{CH}_{3}\right), 52.11$ $\left(\mathrm{CH}_{2}\right), 53.02\left(2 \mathrm{CH}_{2}\right), 160.35(\mathrm{Cq}), 178.80(\mathrm{Cq})$; EI-MS m/z $159\left(\mathrm{M}^{+}\right)$. Anal. $\left(\mathrm{C}_{5} \mathrm{H}_{9} \mathrm{~N}_{3} \mathrm{OS}\right) \mathrm{C}$, $\mathrm{H}, \mathrm{N}$. 
5-Cyclohexyl-3H-[1,3,4]oxadiazole-2-thione (10d)—Starting from 8d compound 10d was prepared according to procedure $\mathrm{E}$, and chromatographed: slightly yellow crystals (46\%); $\mathrm{mp}=81{ }^{\circ} \mathrm{C} ; \mathrm{R}_{\mathrm{f}}$ (petroleum ether/ethyl acetate $\left.=5 / 1\right): 0.3 ;{ }^{1} \mathrm{H}$ NMR $\left(\right.$ DMSO- $\left.\mathrm{d}_{6}\right) \delta 1.14-1.48$ $(\mathrm{m}, 5 \mathrm{H}, 5 \mathrm{CH}), 1.57-1.71(\mathrm{~m}, 3 \mathrm{H}, 3 \mathrm{CH}), 1.90-1.93(\mathrm{~m}, 2 \mathrm{H}, 2 \mathrm{CH}), 2.74-2.84(\mathrm{~m}, 1 \mathrm{H}, \mathrm{CH})$, $14.32(\mathrm{~s}, 1 \mathrm{H}, \mathrm{NH}) ;{ }^{13} \mathrm{C}$ NMR $\left(\mathrm{DMSO}-\mathrm{d}_{6}\right) \delta 24.79\left(2 \mathrm{CH}_{2}\right), 25.34\left(\mathrm{CH}_{2}\right), 29.05\left(2 \mathrm{CH}_{2}\right), 34.44$ $(\mathrm{CH}), 167.10(\mathrm{Cq}), 177.87(\mathrm{Cq})$; EI-MS $m / z 184\left(\mathrm{M}^{+}\right)$. Anal. $\left(\mathrm{C}_{8} \mathrm{H}_{12} \mathrm{~N}_{2} \mathrm{OS}\right) \mathrm{C}, \mathrm{H}, \mathrm{N}$.

5-Methyl-3H-[1,3,4]oxadiazole-2-thione (10e)—Starting from 8e compound 10e was prepared according to procedure $\mathrm{E}$, and chromatographed: white crystals $(17 \%) ; \mathrm{mp}=78^{\circ}$ $\mathrm{C}^{64} ; \mathrm{R}_{\mathrm{f}}$ (petroleum ether/ethyl acetate $=5 / 1$ ): 0.1; NMR data agreed with literature ${ }^{65}$. EI-MS $m / z 117\left(\mathrm{M}^{+}+1\right)$. Anal. $\left(\mathrm{C}_{3} \mathrm{H}_{4} \mathrm{~N}_{2} \mathrm{OS}\right) \mathrm{C}, \mathrm{H}, \mathrm{N}$.

\section{General Procedures for the Synthesis of [1,3,4]Oxadiazols: Procedure I}

(Compounds 11, 18)-The hydrazide was refluxed for two hours in excess triethoxyalkane. Afterwards alcohol which is formed during the reaction was removed by distillation. The residue was refluxed for 5 hours. After cooling to RT, the mixture was treated with water, saturated with $\mathrm{K}_{2} \mathrm{CO}_{3}$ and extracted several times with ethyl acetate. The combined organic extracts were dried $\left(\mathrm{Na}_{2} \mathrm{SO}_{4}\right)$, evaporated and chromatographed (62-66\%).

1-Be nzyl-4-[1,3,4]oxadiazol-2-yl-piperidine. (11)—Starting from $8 \mathrm{~b}$ and triethoxyethane the compound was prepared according to procedure I, and chromatographed starting with petroleum ether/ethyl acetate $=1 / 1$ and switching to methanol/ethyl acetate $=1 / 1$ : white slightly beige crystals $(62 \%) ; \mathrm{mp}=61^{\circ} \mathrm{C} ; \mathrm{R}_{\mathrm{f}}$ (ethyl acetate/petroleum ether $\left.=1 / 1\right): 0.1$; $\mathrm{R}_{\mathrm{f}}$ (methanol/ethyl acetate $\left.=1 / 1\right): 0.4 ;{ }^{1} \mathrm{H}$ NMR $\left(\mathrm{DMSO}_{-} \mathrm{d}_{6}\right) \delta 1.64-1.77(\mathrm{~m}, 2 \mathrm{H}, 2 \mathrm{CH}), 1.90$ $2.00(\mathrm{~m}, 2 \mathrm{H}, 2 \mathrm{CH}), 2.03-2.11(\mathrm{~m}, 2 \mathrm{H}, 2 \mathrm{CH}), 2.74-2.84(\mathrm{~m}, 2 \mathrm{H}, 2 \mathrm{CH}), 2.89-2.99(\mathrm{~m}, 1 \mathrm{H}, \mathrm{CH})$, $3.45\left(\mathrm{~s}, 2 \mathrm{H}, \mathrm{CH}_{2}-\mathrm{Ph}\right), 7.18-7.32\left(\mathrm{~m}, 5 \mathrm{H}, \mathrm{CH}_{\mathrm{Ar}}\right.$ ), 9.13 (s, $1 \mathrm{H}, \mathrm{CH}_{\text {Oxadiazole }}$ ); ${ }^{13} \mathrm{C}$ NMR (DMSO$\left.\mathrm{d}_{6}\right) \delta 29.32\left(2 \mathrm{CH}_{2}\right), 32.55(\mathrm{CH}), 52.31\left(2 \mathrm{CH}_{2}\right), 62.56\left(\mathrm{CH}_{2}\right), 127.17(\mathrm{CH}), 128.45(2 \mathrm{CH})$, $129.05(2 \mathrm{CH}), 138.63(\mathrm{Cq}), 154.46(\mathrm{CH}), 168.67$; EI-MS m/z $244\left(\mathrm{M}^{+}\right)$. Anal. $\left(\mathrm{C}_{14} \mathrm{H}_{17} \mathrm{~N}_{3} \mathrm{O}\right)$ $\mathrm{C}, \mathrm{H}, \mathrm{N}$.

4-Benzyl-5-piperidin-4-yl-2,4-dihydro-[1,2,4]triazol-3-one Hydrochloride. (16a) - Starting from 14a compound 16a was synthesized as described in procedure $\mathrm{F}$ : white crystals $(66 \%) ; \mathrm{mp}=251{ }^{\circ} \mathrm{C} ;{ }^{1} \mathrm{H}$ NMR $\left(\mathrm{DMSO}_{-} \mathrm{d}_{6}\right) \delta 1.65-1.80(\mathrm{~m}, 4 \mathrm{H}, 4 \mathrm{CH}), 2.77-2.95(\mathrm{~m}, 3 \mathrm{H}$, $3 \mathrm{CH}), 3.15-3.25(\mathrm{~m}, 2 \mathrm{H}, 2 \mathrm{CH}), 4.81\left(\mathrm{~s}, 2 \mathrm{H}, \mathrm{CH}_{2}-\mathrm{Ph}\right), 7.21-7.37$ (m, 5H, $\left.\mathrm{CH}_{\mathrm{Ar}}\right), 8.85-9.25$ $\left(\mathrm{m}, 2 \mathrm{H}, \mathrm{NH}_{2}\right), 11.70(\mathrm{~s}, 1 \mathrm{H}, \mathrm{NH}) ;{ }^{13} \mathrm{C}$ NMR $\left(\mathrm{DMSO}_{6}\right) \delta 26.29\left(2 \mathrm{CH}_{2}\right), 30.21(\mathrm{CH}), 42.48$ $\left(2 \mathrm{CH}_{2}\right), 43.36\left(\mathrm{CH}_{2}\right), 78.44(\mathrm{Cq}), 127.19(2 \mathrm{CH}), 127.89(\mathrm{CH}), 129.03(2 \mathrm{CH}), 137.31(\mathrm{Cq})$, $149.47(\mathrm{Cq}), 155.30(\mathrm{Cq})$; EI-MS m/z $258\left(\mathrm{M}^{+}\right)$. Anal. $\left(\mathrm{C}_{13} \mathrm{H}_{19} \mathrm{~N}_{4} \mathrm{O} \cdot \mathrm{HCl} \cdot 5 / 4 \mathrm{H}_{2} \mathrm{O}\right) \mathrm{C}, \mathrm{H}, \mathrm{N}$.

5-Aminomethyl-4-benzyl-2,4-dihydro-[1,2,4]triazol-3-one. (16d)—Starting from 12d compound 16a was synthesized as described in procedure $L$, since no precipitate was formed the mixture was extracted with several portions of ethyl acetate. The combined organic extracts were dried $\left(\mathrm{Na}_{2} \mathrm{SO}_{4}\right)$ and the solvent evaporated under vacuo until the crystallization started: white crystals $(44 \%) ; \mathrm{mp}=150{ }^{\circ} \mathrm{C} ;{ }^{1} \mathrm{H}$ NMR $\left(\right.$ DMSO-d $\left._{6}\right) \delta 1.78\left(\mathrm{~s}, 2 \mathrm{H}, \mathrm{NH}_{2}\right), 3.44$ $\left(\mathrm{s}, 2 \mathrm{H}, \mathrm{CH}_{2} \mathrm{~N}\right), 4.86\left(\mathrm{~s}, 2 \mathrm{H}, \mathrm{CH}_{2}-\mathrm{Ph}\right), 7.22-7.37\left(\mathrm{~m}, 5 \mathrm{H}, \mathrm{CH}_{\mathrm{Ar}}\right), 11.55(\mathrm{~s}, 1 \mathrm{H}, \mathrm{NH}) ;{ }^{13} \mathrm{C} \mathrm{NMR}$ $\left(\right.$ DMSO-d $\left._{6}\right) \delta 37.76\left(\mathrm{CH}_{2}\right), 43.30\left(\mathrm{CH}_{2}\right), 127.35(2 \mathrm{CH}), 127.80(\mathrm{CH}), 128.96(2 \mathrm{CH}), 137.38$ $(\mathrm{Cq}), 148.79(\mathrm{Cq}), 155.73(\mathrm{Cq})$; EI-MS m/z $204\left(\mathrm{M}^{+}\right)$. Anal. $\left(\mathrm{C}_{10} \mathrm{H}_{12} \mathrm{~N}_{4} \mathrm{O}\right) \mathrm{C}, \mathrm{H}, \mathrm{N}$.

\section{4-Benzyl-5-piperidin-4-yl-2,4-dihydro-[1,2,4]triazol-3-thione Hydrochloride.}

(17a)-Starting from 15 compound 17a was synthesized as described in procedure F: white crystals $(95 \%) ; \mathrm{mp}=285^{\circ} \mathrm{C} ;{ }^{1} \mathrm{H}$ NMR $\left(\right.$ DMSO$\left._{-} \mathrm{d}_{6}\right) \delta 1.63-1.78(\mathrm{~m}, 4 \mathrm{H}, 4 \mathrm{CH}), 2.79-2.91(\mathrm{~m}$, $2 \mathrm{H}, 2 \mathrm{CH}$ ), 2.98-3.08 (m, 1H, CH), 3.14-3.22 (m, 2H, 2CH), 5.27 (s, 2H, $\left.\mathrm{Ch}_{2}-\mathrm{Ph}\right), 7.26-7.37$ $\left(\mathrm{m}, 5 \mathrm{H}, \mathrm{CH}_{\mathrm{Ar}}\right), 8.68-9.04\left(\mathrm{~m}, 2 \mathrm{H}, \mathrm{NH}_{2}\right), 13.83(\mathrm{~s}, 1 \mathrm{H}, \mathrm{NH}) ;{ }^{13} \mathrm{C}$ NMR $\left(\mathrm{DMSO}_{6}\right) \delta 26.64$ 
$\left(2 \mathrm{CH}_{2}\right), 30.31(\mathrm{CH}), 42.49\left(2 \mathrm{CH}_{2}\right), 45.91\left(\mathrm{CH}_{2}\right), 127.36(2 \mathrm{CH}), 128.12(\mathrm{CH}), 129.03(2 \mathrm{CH})$, $136.29(\mathrm{Cq}), 154.60(\mathrm{Cq}), 167.43(\mathrm{Cq})$; EI-MS m/z $274\left(\mathrm{M}^{+}\right)$. Anal.

$\left(\mathrm{C}_{14} \mathrm{H}_{18} \mathrm{~N}_{4} \mathrm{~S} \cdot \mathrm{HCl} \cdot 5 / 4 \mathrm{H}_{2} \mathrm{O}\right) \mathrm{C}, \mathrm{H}, \mathrm{N}, \mathrm{S}$.

5-Aminomethyl-4-benzyl-2,4-dihydro-[1,2,4]triazol-3-thione. (17d)—Starting from 13d compound 17d was synthesized as described in procedure $\mathrm{L}$, and chromatographed with petroleum ether/ethyl acetate $=1 / 3$ to wash off most of the intermediate BOC-protected triazole-3-thione, and then with ethyl acetate/methanol $=1 / 5$, and subsequently with

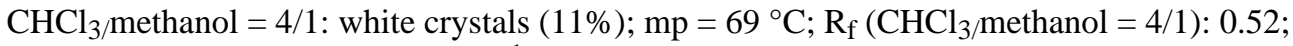
white crystals $(11 \%) ; \mathrm{mp}=158{ }^{\circ} \mathrm{C} ;{ }^{1} \mathrm{H}$ NMR $\left(\mathrm{DMSO}_{-} \mathrm{d}_{6}\right) \delta 2.07\left(\mathrm{~s}, 2 \mathrm{H}, \mathrm{NH}_{2}\right), 3.15(\mathrm{~s}, 1 \mathrm{H}$, $\mathrm{NH}), 3.55$ (s, $\left.2 \mathrm{H}, \mathrm{CH}_{2} \mathrm{NH}_{2}\right), 5.32$ (s, $\left.2 \mathrm{H}, \mathrm{CH}_{2}-\mathrm{Ph}\right), 7.26-7.39$ (m, $\left.5 \mathrm{H}, \mathrm{CH}_{\mathrm{Ar}}\right) ;{ }^{13} \mathrm{C} \mathrm{NMR}$ $\left(\right.$ DMSO-d $\left.{ }_{6}\right) \delta 37.23\left(\mathrm{CH}_{2}\right), 45.71\left(\mathrm{CH}_{2}\right), 127.39(2 \mathrm{CH}), 128.02(\mathrm{CH}), 128.98(2 \mathrm{CH}), 136.24$ $(\mathrm{Cq}), 153.74(\mathrm{Cq}), 167.89(\mathrm{Cq})$; EI-MS m/z, $220\left(\mathrm{M}^{+}\right)$. Anal. $\left(\mathrm{C}_{10} \mathrm{H}_{12} \mathrm{~N}_{4} \mathrm{~S} \cdot 9 / 10 \mathrm{H}_{2} \mathrm{O}\right) \mathrm{C}, \mathrm{H}, \mathrm{N}$, $\mathrm{S}$.

4-(5-Methyl-[1,3,4]oxadiazol-2-yl)-piperidine Hydrochloride. (19)—Starting from 18 the compound was synthesized as described in general procedure $\mathrm{G}(56 \%)$; the corresponding hydrobromide was obtained by stirring $2.6 \mathrm{mmol}$ of $18 \mathrm{in} 1 \mathrm{~mL}$ of $\mathrm{HBr}$ in Acetic Acid (5.7 M) under a nitrogen atmosphere overnight (98\%). Analytical data for the hydrochloride: $\mathrm{mp}=193{ }^{\circ} \mathrm{C} ;{ }^{1} \mathrm{H}$ NMR $\left(\right.$ DMSO- $\left._{6}\right) \delta 1.85-1.99(\mathrm{~m}, 2 \mathrm{H}, 2 \mathrm{CH}), 2.09-2.14(\mathrm{~m}$, $2 \mathrm{H}, 2 \mathrm{CH}), 2.45\left(\mathrm{~s}, 3 \mathrm{H}, \mathrm{CH}_{3}\right), 2.94-3.05(\mathrm{~m}, 2 \mathrm{H}, 2 \mathrm{CH}), 3.22-3.33(\mathrm{~m}, 3 \mathrm{H}, 3 \mathrm{CH}), 9.11-9.35$ $\left(\mathrm{m}, 2 \mathrm{H}, \mathrm{NH}_{2}\right) ;{ }^{13} \mathrm{C}$ NMR (DMSO-d 6$) \delta 10.80\left(\mathrm{CH}_{3}\right), 25.66\left(2 \mathrm{CH}_{2}\right), 30.24(\mathrm{CH}), 42.13$ $\left(2 \mathrm{CH}_{2}\right), 163.98(\mathrm{Cq}), 167.68(\mathrm{Cq})$. Anal. $\left(\mathrm{C}_{8} \mathrm{H}_{13} \mathrm{~N}_{3} \mathrm{O} \cdot \mathrm{HCl} \cdot 5 / 3 \mathrm{H}_{2} \mathrm{O}\right) \mathrm{C}, \mathrm{H}, \mathrm{N}$.

$\left[{ }^{3} \mathrm{H}\right]$ Muscimol Ligand binding assays-Adult, male Sprague-Dawley rats (supplied by the Department of Laboratory Animals, University of Mainz) were decapitated, their brains removed and cerebellum and cortex separated. The tissue was homogenized in $50 \mathrm{mM}$ Tris/ citrate, $\mathrm{pH} 7.3$, in an Ultraturrax (IKA, Staufen, Germany) for $15 \mathrm{sec}$. The membranes were centrifuged at $43,000 \times \mathrm{g}$ for $20 \mathrm{~min}$. The washing step was repeated four times before the membranes were frozen at $-20^{\circ} \mathrm{C}$. After slow thawing the washing steps were repeated another two times and frozen again until use. Before each experiment the membranes were recentrifuged and diluted to the desired protein concentration. Resuspended cell membranes $(50-200 \mu \mathrm{g}$ protein per tube) were incubated in a final volume of $0.5 \mathrm{ml}$ of $50 \mathrm{mM}$ Tris/citrate buffer, $\mathrm{pH} 7.3$, for $\left[{ }^{3} \mathrm{H}\right]$ muscimol binding $(6 \mathrm{nM})$ with and without the novel compounds in the concentration range given in the text. Non-specific binding was determined in the presence of $100 \mu \mathrm{M}$ GABA. After $60 \mathrm{~min}$ on ice the assay mixtures were rapidly diluted to $5 \mathrm{ml}$ with ice-cold $10 \mathrm{mM}$ Tris/HCl, pH 7.4, filtered through glass fiber filters (\# 52, Schleicher \& Schuell, Dassel, Germany) and washed once with $5 \mathrm{ml} 10 \mathrm{mM}$ Tris/HCl, $\mathrm{pH}$ 7.4. Filters were immersed in $4 \mathrm{ml}$ of Zinsser AquaSolv (Munich, Germany) scintillation fluid, and the radioactivity determined in a Beckman liquid scintillation counter using external standardization. Statistical calculations were performed using the Graph Pad Prism program (GraphPad Software, San Diego, CA.) with and without the novel compounds.

Cell culturing and cell transfection-For electrophysiological recording, HEK-293 cells were passaged and replated on 12-mm glass coverslips located in 9.6-cm plastic dishes filled with $10 \mathrm{ml}$ of Minimum Essential Medium (MEM, Gibco) supplemented with $158 \mathrm{mg} / \mathrm{l}$ sodium bicarbonate, $2 \mathrm{mM}$ glutamine (Gibco), $100 \mathrm{U} / \mathrm{ml}$ penicillin-streptomycin (Gibco), and 10\% fetal calf serum (Gibco). Cultures were maintained at $37{ }^{\circ} \mathrm{C}$ in a humidified $95 \% \mathrm{O}_{2} / 5 \%$ $\mathrm{CO}_{2}$ atmosphere for 2-3 days.

Transfection with recombinant rat $\mathrm{GABA}_{\mathrm{A}}$ receptors were carried out as described in detail $^{66,67}$. Briefly, HEK 293 cells were transfected using the calcium phosphate precipitation method with rat $\mathrm{GABA}_{\mathrm{A}}$ receptor cDNAs in eukaryotic expression vectors 68 for the $\alpha, \beta$ and 
$\gamma$ subunits. For optimal receptor expression, final concentrations ( $\mu$ g vector DNA per $9.6 \mathrm{~cm}$ tissue culture plate) were: $\alpha_{1}, 2 ; \alpha_{2} 4.8 ; \alpha_{3}, 1.2 ; \alpha_{4} 10 ; \alpha_{5}, 0.8 ; \alpha_{6}, 2 ; \beta_{3}, 0.4 ;$ and $\gamma_{2} S, 0.3$. The $\gamma_{2} \mathrm{~S}$ variant is abbreviated $\gamma_{2}$ in the remainder of the text. To identify transfected cells all subunit combinations were co-transfected with $1 \mu \mathrm{g}$ per plate of pNI-EGFP.

HEK293 Electrophysiology-Two days after transfection single coverslips containing HEK 293 cells were placed in a recording chamber mounted on the movable stage of a fluorescence microscope (Olympus IX70) and perfused with a defined saline solution containing (in $\mathrm{mM}$ ): $130 \mathrm{NaCl}, 5.4 \mathrm{KCl}, 2 \mathrm{CaCl}_{2}, 2 \mathrm{MgSO}_{4}, 10$ glucose, 5 sucrose, and 10 HEPES (free acid), $\mathrm{pH}$ adjusted to 7.35 with $\mathrm{NaOH}$. Transfected cells were identified by their green fluorescence due to the expression of the pNI-EGFP vector. Ligand-mediated membrane currents from these cells were studied using the whole-cell patch-clamp recording technique ${ }^{69}$. Patch pipettes were pulled from hard borosilicate capillary glass $(0.5 \mathrm{~mm} \mathrm{ID}, 1.5$ mm OD, Vitrex, Science Products GmbH, Hofheim, Germany) using a horizontal puller (Sutter Instruments, CA, Model P-97) in a multi-stage process. The pipettes had an initial resistance of 2-4 M $\Omega$ when filled with a solution containing (in $\mathrm{mM}$ ): $90 \mathrm{KCl}, 50 \mathrm{KOH}, 2 \mathrm{CaCl}_{2}, 2$ $\mathrm{MgCl}_{2}, 10$ EGTA, 3.1 ATP (di-potassium salt), 0.4 GTP (tri-sodium salt), and 10 HEPES (free acid), $\mathrm{pH} 7.35$.

The junction potential between the pipette and the external solution was less than $2.3 \mathrm{mV}$ and therefore was neglected. Seal resistances $>1 \mathrm{G} \Omega$ were routinely obtained by applying gentle suction to the pipettes. Membrane rupture was monitored electrically as an increase in capacitance. Pipette capacitance, membrane capacitance, and series resistance were electronically compensated to minimize capacitive transients. A series resistance compensation of $>60 \%$ was regularly used.

To analyze modulations of the GABA-induced currents the approximate receptor subtype specific $\mathrm{GABA} \mathrm{EC}_{20}$ and increasing drug concentrations were applied to the cells using a fast perfusion stepper system (SF-77B, Perfusion Fast Step, Warner Instruments, Inc., Midwest, USA). In the case of $\mathbf{5 a}$ and $\mathbf{6 a}$ the following concentrations were co-applied (in $\mu \mathrm{M}$ ): $0.1,1$, 10, 100, 1000, for $\mathbf{1 9}$ and $\mathbf{5 d}$ the concentration range used was (in M): 0.1, 0.3, 1, 3, 10, 30, $100,300,1000$. Additionally the intrinsic activity of all compounds was tested by applying them alone to the cells in concentrations of $1,10,100$, and $1000 \mu \mathrm{M}$.

Responses of cells were recorded by patch-clamp amplifier (EPC-8, HEKA-Electronic, Lambrecht, Germany) in conjunction with a standard personal computer and the pClamp 8.1 software package (Axon Instruments, Foster City, CA). The standard holding-potential for the cells was $-40 \mathrm{mV}$. Whole cell currents were low-pass filtered by a eight-pole Bessel filter at 5 or $3 \mathrm{kHz}$ before being digitized by a Digidata 1322A interface (Axon Instruments, Foster City, CA) and recorded by the computer at a sampling rate of at least $5 \mathrm{kHz}$.

Mutagenesis and oocyte expression-The rat GABA $A_{\mathrm{A}}$ receptor $\alpha_{1}$ and $\beta_{2}$ subunit DNA constructs in the pGH19 vector ( $a_{1}$ wild-type (wt), $\alpha_{1} \mathrm{~F} 64 \mathrm{C}, \alpha_{1} \mathrm{R} 66 \mathrm{C}, \alpha_{1} \mathrm{~S} 68 \mathrm{C}, \alpha_{1} \mathrm{~T} 129 \mathrm{C}, \beta_{2}$ wt) were obtained from Dr. Cynthia Czajkowski, University of Wisconsin-Madison. Their identity was verified by restriction digestion and DNA sequencing. Plasmids were linearized with NheI prior to in vitro mRNA transcription with T7 RNA polymerase (Amplicap T7 High Yield Message MakerTM, Epicentre Technologies, Madison, WI). mRNA was dissolved in diethylpyrocarbamate-treated water, and stored at $-80{ }^{\circ} \mathrm{C}$. Female Xenopus laevis were purchased from Nasco Science (Fort Atkinson, WI). Stage V-VI oocytes were defolliculated with a 75 minute treatment with $2 \mathrm{mg} / \mathrm{ml}$ Type 1 A collagenase (Sigma Chemical Co., St. Louis, MO) in OR2 ( $82.5 \mathrm{mM} \mathrm{NaCl}, 2 \mathrm{mM} \mathrm{KCl}, 1 \mathrm{mM} \mathrm{MgCl}_{2}$, and $5 \mathrm{mM}$ HEPES; $\mathrm{pH}$ adjusted to 7.5 with $\mathrm{NaOH})$. Oocytes were washed thoroughly in OR2 and kept in SOS medium $(82.5 \mathrm{mM}$ $\mathrm{NaCl}, 2.5 \mathrm{mM} \mathrm{KCl}, 1 \mathrm{mM} \mathrm{MgCl} 2,5 \mathrm{mM}$ HEPES, pH 7.5) supplemented with $1 \%$ Antibiotic- 
Antimycotic (100X) liquid (10,000 IU/ml penicillin, 10,000 $\mu \mathrm{g} / \mathrm{ml}$ streptomycin, and $25 \mu \mathrm{g} /$ $\mathrm{ml}$ of amphotericin B; Invitrogen, Carlsbad, CA) and 5\% horse serum (Sigma). Oocytes were injected $24 \mathrm{~h}$ after isolation with $50 \mathrm{nl}(10 \mathrm{ng})$ of a 1:1 mixture of rat $\alpha_{1}: \beta_{2}$ subunit mRNA and were kept in horse serum medium for 2 to 10 days at $17{ }^{\circ} \mathrm{C}$. Mutant subunit mRNA was substituted for wt $\alpha_{1}$ subunit where necessary ${ }^{70}$.

Two electrode voltage clamp recording-The electrophysiological recordings were conducted at room temperature in a $\sim 250-\mu$ l chamber continuously perfused at a rate of 5 to 6 $\mathrm{ml} / \mathrm{min}$ with $\mathrm{Ca}^{2+}{ }_{-}$free frog Ringer buffer (CFFR; $115 \mathrm{mM} \mathrm{NaCl}, 2.5 \mathrm{mM} \mathrm{KCl}, 1.8 \mathrm{mM}$ $\mathrm{MgCl}_{2}, 10 \mathrm{mM}$ HEPES pH 7.5 with $\mathrm{NaOH}$ ) using equipment and procedures described previously 52 . Currents were recorded from individual oocytes using two-electrode voltageclamp at a holding potential of $-60 \mathrm{mV}$. The ground electrode was connected to the bath via a $3 \mathrm{M} \mathrm{KCl} /$ Agar bridge. Glass microelectrodes had a resistance of $<2 \mathrm{M} \Omega$ when filled with 3 M KCl. Data were acquired and analyzed using a TEV-200 amplifier (Dagan Instruments, Minneapolis, MN), a Digidata 1200 or Digidata 1322A data interface (Axon Instruments, Union City, CA), and pClamp 7 or pClamp 8 software (Axon Instruments). Currents ( $\mathrm{I}_{\mathrm{GABA}}$ ) were elicited by applications of GABA separated by at least 5 min of CFFR wash to allow complete recovery from desensitization. Currents were judged to be stable if the variation between consecutive GABA pulses was $<10 \%$.

Reagents-The sulfhydryl-reactive methanethiosulfonate (MTS) reagents used in these experiments were 2-sulfonatoethyl methanethiosulfonate (MTSES $\left.{ }^{-}\right)$and 2-((biotinoyl)amino) ethyl methanethiosulfonate (MTSEA-biotin) (Biotium, Inc., Hayward, CA). MTS-reagents react with cysteine (Cys) and covalently couple a 2-sulfonatoethylsulfide (MTSES ${ }^{-}$) or a 2((biotinoyl)amino)ethylsulfide moiety (MTSEA-biotin) onto protein sulfhydryls. A $100 \mathrm{mM}$ stock solution of MTSES $^{-}$in water or MTSEA-biotin in DMSO was prepared daily and kept on ice. The working solutions were obtained by diluting the $100 \mathrm{mM}$ stock solution in CFFR immediately before use. GABA (Sigma) was prepared as a $100 \mathrm{mM}$ stock solution in water. Dithiothreitol (DTT) (Sigma) was dissolved in water to obtain a $1 \mathrm{M}$ stock solution and diluted into CFFR before each experiment.

GABA and 6a Concentration-Response Relationships-The $\mathrm{GABA} \mathrm{EC}_{50}$ s for wt or mutant $\alpha_{1} \beta_{2}$ receptors were determined using the two-electrode voltage clamp technique on Xenopus laevis oocytes. To determine the GABA concentration-response relationship, progressively increasing GABA concentrations were applied to oocytes expressing wt or mutant receptors. The currents were normalized to the maximal GABA-induced current $\left(\mathrm{I}_{\max }\right)$. The GABA concentration-response relationship was determined for each mutant by least-squares minimization (GraphPad Prism 3.0, GraphPad Software Inc., San Diego, CA; SigmaPlot 2000, SPSS Inc., Chicago, IL) of the currents to a logistic equation of the form:

$$
I / I_{\max }=1 /\left(1+\left(\mathrm{EC}_{50} /[\mathrm{GABA}]\right)^{n}\right)
$$

where $n$ is the Hill coefficient and $\mathrm{EC}_{50}$ is the GABA concentration that gives rise to $50 \%$ of the maximal current. Parameters from several oocytes were averaged to obtain the mean $\mathrm{EC}_{50}$ and Hill coefficient. Data are presented as mean \pm S.E.M. except where the number of experiments performed is two in which case average errors are given.

For $\alpha_{1} \beta_{2}$ wt, $\alpha_{1} \mathrm{~F} 64 \mathrm{C} \beta_{2}$, and $\alpha_{1} \mathrm{~S} 68 \mathrm{C} \beta_{2}$ receptors we also performed concentration-response experiments with $\mathbf{6 a}$ - which directly activates at high concentrations - to measure the $\mathrm{EC}_{50}$ for this compound. For $\mathbf{6 a}$ dose-response curves only two trials were performed for some mutants due to the limited supply of $\mathbf{6 a}$.

Determination of $\mathbf{6} \mathbf{a} \mathbf{I C}_{\mathbf{5 0}}$-The $\mathrm{IC}_{50}$ for $\mathbf{6 a}$ was determined by co-applying progressively increasing test concentrations of $\mathbf{6} \mathbf{a}$ with a constant GABA concentration. For each receptor 
the $\mathrm{GABA} \mathrm{EC}_{20}$ concentration was used. We used a low GABA concentration for our inhibition experiments because of the limited availability of 6a. Inhibition was calculated as

$\mathrm{I}_{\mathrm{GABA}}+\mathbf{6 a} / \mathrm{I}_{\mathrm{GABA}}$. Data were fit to the following equation: inhibition $=1-1 /\left(1+\left(\mathrm{IC}_{50} /[\mathbf{6 a}]\right)^{n}\right)$

where $\mathrm{IC}_{50}$ is the concentration of $\mathbf{6 a}$ that blocks half of $\mathrm{I}_{\mathrm{GABA}}$; [6a] is the concentration of 6a, and $n$ is the Hill coefficient.

Picrotoxinin blockade of $\mathbf{6 a}$ induced currents-We applied several $\mathbf{6 a}(10 \mathrm{mM})$ testpulses to $\alpha_{1} \beta_{2}$ receptors and recorded the induced currents. Following wash-out we applied the open-channel blocker picrotoxinin $(100 \mu \mathrm{M})$ immediately followed by a co-application of $\mathbf{6 a}$ and picrotoxinin $(10 \mathrm{mM}$ and $100 \mu \mathrm{M})$ and recorded the current trace.

Determination of MTS-reagent reaction rates-The MTS reagent was applied repeatedly in the extracellular bath for brief periods. Before and between each application of MTS reagent, the GABA-induced current was determined. For each mutant, the MTS-reagent concentration to be used was chosen based on preliminary experiments so that the reaction would proceed to completion in 1 to 2 min of cumulative MTS-reagent application time (MTSES ${ }^{-}$concentrations used: $\alpha_{1}$ F64C, $10 \mu \mathrm{M} ; \alpha_{1}$ R66C, 250 and $500 \mu \mathrm{M} ; \alpha_{1}$ S68C, $150 \mu \mathrm{M}$; $\alpha_{1}$ T129C, $10 \mathrm{nM}$; MTSEA-biotin concentration used: $\alpha_{1}$ R66C, 10 or $40 \mu \mathrm{M} ; \alpha_{1} \mathrm{~T} 129 \mathrm{C}, 10$ $\mathrm{nM}$ ). The peak GABA test currents were normalized to the initial GABA current, plotted as a function of the cumulative MTS-reagent application time and fitted with a monoexponential function of the form,

$$
\mathrm{I}=\left(\mathrm{I}_{0}-\mathrm{I}_{\infty}\right) \mathrm{e}^{-t \tau^{\prime}}+\mathrm{I}_{\infty}
$$

where $\mathrm{I}_{0}$ is the value of the GABA-induced current amplitude before modification, $\mathrm{I}_{\infty}$ is the current amplitude at the end of the reaction, $t$ is the cumulative MTS-reagent application time, and $\tau^{\prime}$ is the pseudo-first-order rate constant $\left(\mathrm{s}^{-1}\right)$. The second-order rate constants, $\tau$, were calculated by dividing the pseudo-first-order time constants $\tau^{\prime}$ by the MTS-reagent concentration. The second-order rate constants were independent of the MTS-reagent concentrations used. MTS-reagent reaction rates were determined for $\alpha_{1} \mathrm{~F} 64 \mathrm{C}, \alpha_{1} \mathrm{R} 66 \mathrm{C}$, as well as $\alpha_{1}$ S68C containing $\alpha_{1} \beta_{2} \mathrm{GABA}_{\mathrm{A}}$ receptors. Data are presented as mean \pm S.E.M. These rates were used to calculate the concentration and time of application of MTS-reagent that produces submaximal, non-saturating inhibition.

Determination of $6 a$ reaction rates in $\alpha_{1} R 66 C \beta_{2}$ receptors- $6 a$ was applied repeatedly in the extracellular bath for brief periods. Before and between each $\mathbf{6 a}$ application the GABA-induced current was determined. The $6 \mathrm{a}$ reaction rate with the engineered $\alpha_{1} \mathrm{R} 66 \mathrm{C}$ was determined as described above for MTS-reagents. Once the alternating $\mathbf{6 a}$ and GABA applications produced a reduced but stable GABA current we applied a saturating amount of $\operatorname{MTSES}^{-}(10 \mathrm{mM}, 12 \mathrm{~s})$ in order to determine whether all of the engineered cysteines had reacted with 6a. In order to demonstrate that the $6 \mathrm{a}$ inhibition of $\alpha_{1} \mathrm{R} 66 \mathrm{C}$ was due to formation of a disulfide bond between 6a and the engineered cysteine thiol we applied DTT (10 mM, 20 s), and measured the GABA current again.

Protection assay with $6 a$ or GABA in mutant $\alpha_{1} \beta_{2}$ receptors-In order to demonstrate that $\mathbf{6 a}$ or GABA bound in close proximity to an engineered cysteine we assayed the ability of these agonists to protect the cysteine from reaction with an MTS reagent. In order to maximize our ability to detect protection we used concentrations of MTS reagents and durations of application that caused large but sub-maximal inhibition of the subsequent GABA test currents. For a 12-sond application, the MTSES $^{-}$concentrations used were: $\alpha_{1}$ F64C, 10 
$\mu \mathrm{M} ; \alpha_{1} \mathrm{R} 66 \mathrm{C}, 2 \mathrm{mM} ; \alpha_{1} \mathrm{~S} 68 \mathrm{C}, 450 \mu \mathrm{M}$; and MTSEA-biotin concentration: $\alpha_{1} \mathrm{R} 66 \mathrm{C}, 30 \mu \mathrm{M}$. To detect protection for a given mutant, an initial GABA test current was determined. We coapplied a concentration-duration of MTS-reagent that produced sub-maximal inhibition together with $\mathbf{6 a}(10$ or $30 \mathrm{mM})$ or GABA EC 90 concentrations. After washout the remaining GABA-induced current was determined. In order to determine the percent inhibition caused by the MTS + $\mathbf{6 a}$ or GABA co-application it was important to determine the maximum extent of inhibition for each oocyte. This was determined by a subsequent application of a saturating amount of MTS reagent (MTSES ${ }^{-}$concentration: $\alpha_{1}$ F64C, $20 \mu \mathrm{M}, 50 \mathrm{~s} ; \alpha_{1}$ R66C, $10 \mathrm{mM}, 12$ $\mathrm{s} ; \alpha_{1}$ S68C, $5 \mathrm{mM}, 12 \mathrm{~s}$; MTSEA-biotin concentration: $\alpha_{1}$ R66C, $300 \mu \mathrm{M}, 12 \mathrm{~s}$ ) followed by a determination of the current induced by a subsequent GABA-test pulse. If the extent of inhibition resulting from co-application of the MTS reagent with $6 \mathbf{a}$ or GABA was less than the extent of inhibition when just the MTS reagent was applied then we inferred that 6a and/ or GABA had protected the cysteine from modification by the MTS reagent.

The amount of reaction was calculated using the equation:

$$
\% \text { reduction }=\left(\mathrm{I}_{0}-\mathrm{I}\right) /\left(\mathrm{I}_{0}-\mathrm{I}_{\infty}\right) \times 100
$$

where $\mathrm{I}_{0}$ is the value of the GABA-induced current amplitude before modification, $\mathrm{I}$ is the current amplitude after application of the concentration and duration of MTS-reagent that produced sub-maximal inhibition with or without ligand (GABA or $\mathbf{6 a}$ ), and $\mathrm{I}_{\infty}$ is the current amplitude at the end of the reaction after maximal inhibition. Note that the MTS-reagent rates of reaction were done by applying the reagents via a continuous perfusion system. In the protection assay we used a syringe application system that allowed us to use small volumes because of the limited availability of $\mathbf{6 a}$.

Homology modeling - The extracellular domains of rat GABA $A_{A}$ receptor $\alpha_{1}$ and $\beta_{2}$ subunits were modeled on the basis of the $2.2 \AA$ crystal structure of the homologous homopentameric Acetylcholine-Binding Protein (AChBP) with nicotine bound (PDB \# 1UW6). Using Deep View/Swiss Pdb-Viewer v3.7 71 we aligned the $\alpha_{1}$ and $\beta_{2}$ subunit sequences with the AChBP $\mathrm{A}$ and $\mathrm{E}$ chain, respectively 57 . The AChBP structure aligned with the raw sequence was submitted as a modeling request in Swiss Model. The resulting homology modeled $\alpha_{1} \beta_{2}$ structure was subsequently subjected to energy minimization and later rendered with POVRay v3.6 (http://www.povray.org/) 72 .

\section{Supplementary Material}

Refer to Web version on PubMed Central for supplementary material.

\section{Acknowledgements}

We thank Dr. Cindy Czajkowski (Univ. of Wisconsin-Madison) for the generous gift of the GABAA receptor $\alpha_{1}$ subunit cysteine-substitution mutants. We thank Rachel Berkowitz (Albert Einstein College of Medicine), Monique Jakob, Johanna Jambor, Matthias Platz (Univ. of Mainz) for technical assistance and Moez Bali, Amal Bera, Jeffrey Horenstein, David Liebelt and David Reeves (Albert Einstein College of Medicine) for helpful discussions and also for comments on this manuscript. We thank Angela Bauer, Inna Giesbrecht, Werner Kiefer, Angelika Krau $\beta$, Christian Peifer and Philip Prech (Univ. of Mainz) for helpful discussions on the synthesis. Supported in part by grants from the National Institutes of Health NS030808 and GM077660 (to MHA) and by K99NS059841 (to MJ) and by a Deutsche Forschungsgemeinschaft fellowship to MJ (JA-1081/1). Financial support by the Deutsche Forschungsgemeinschaft (HL), 'Fonds der Chemischen Industrie' (HL, HR) is gratefully acknowledged.

\section{Abbreviations}

ACh

acetylcholine 
AChBP

acetylcholine binding protein

DTT

dithiothreitol

GABA

$\gamma$-aminobutyric acid

$\mathbf{G A B A}_{\mathbf{A}}$

GABA Type A receptors

MTS

methanethiosulfonate

MTSES

methanethiosulfonate ethylsulfonate

SCAM

substituted cysteine accessibility method

\section{References}

1. Barnard EA, Skolnick P, Olsen RW, Mohler H, Sieghart W, Biggio G, Braestrup C, Bateson AN, Langer SZ. International Union of Pharmacology. XV. Subtypes of gamma-aminobutyric acidA receptors: classification on the basis of subunit structure and receptor function. Pharmacol Rev 1998;50 (2):291-313. [PubMed: 9647870]

2. Bonnert TP, McKernan RM, Farrar S, le Bourdelles B, Heavens RP, Smith DW, Hewson L, Rigby MR, Sirinathsinghji DJ, Brown N, Wafford KA, Whiting PJ. theta, a novel gamma-aminobutyric acid type A receptor subunit. Proc Natl Acad Sci U S A 1999;96(17):9891-6. [PubMed: 10449790]

3. Sinkkonen ST, Hanna MC, Kirkness EF, Korpi ER. GABA(A) receptor epsilon and theta subunits display unusual structural variation between species and are enriched in the rat locus ceruleus. $\mathrm{J}$ Neurosci 2000;20(10):3588-95. [PubMed: 10804200]

4. Böhme I, Rabe H, Lüddens H. Four amino acids in the alpha subunits determine the gammaaminobutyric acid sensitivities of GABAA receptor subtypes. J Biol Chem 2004;279(34):35193-200. [PubMed: 15199051]

5. Sieghart W, Sperk G. Subunit composition, distribution and function of GABA(A) receptor subtypes. Curr Top Med Chem 2002;2(8):795-816. [PubMed: 12171572]

6. Nusser Z, Sieghart W, Somogyi P. Segregation of different $\mathrm{GABA}_{\mathrm{A}}$ receptors to synaptic and extrasynaptic membranes of cerebellar granule cells. J Neurosci 1998;18(5):1693-703. [PubMed: 9464994]

7. Fritschy JM, Johnson DK, Mohler H, Rudolph U. Independent assembly and subcellular targeting of GABA(A)-receptor subtypes demonstrated in mouse hippocampal and olfactory neurons in vivo. Neurosci Lett 1998;249(2-3):99-102. [PubMed: 9682826]

8. Luddens H, Korpi ER. Biological function of GABAA/benzodiazepine receptor heterogeneity. J Psychiatr Res 1995;29(2):77-94. [PubMed: 7545236]

9. Quirk K, Blurton P, Fletcher S, Leeson P, Tang F, Mellilo D, Ragan CI, McKernan RM. [3H]L-655,708, a novel ligand selective for the benzodiazepine site of GABAA receptors which contain the alpha 5 subunit. Neuropharmacology 1996;35(9-10):1331-5. [PubMed: 9014149]

10. Skolnick P, Hu RJ, Cook CM, Hurt SD, Trometer JD, Liu R, Huang Q, Cook JM. [3H]RY 80: A high-affinity, selective ligand for gamma-aminobutyric acidA receptors containing alpha- 5 subunits. J Pharmacol Exp Ther 1997;283(2):488-93. [PubMed: 9353361]

11. Luddens H, Pritchett DB, Kohler M, Killisch I, Keinanen K, Monyer H, Sprengel R, Seeburg PH. Cerebellar GABAA receptor selective for a behavioural alcohol antagonist. Nature 1990;346(6285): 648-51. [PubMed: 2166916] 
12. Wisden W, Seeburg PH. GABA $A_{A}$ receptor channels: from subunits to functional entities. Current Opinions in Neurobiology 1992;2:263-269.

13. Pritchett DB, Sontheimer H, Shivers BD, Ymer S, Kettenmann H, Schofield PR, Seeburg PH. Importance of a novel $\mathrm{GABA}_{\mathrm{A}}$ receptor subunit for benzodiazepine pharmacology. Nature 1989;338:582-585. [PubMed: 2538761]

14. Sigel E, Buhr A. The benzodiazepine binding site of $\mathrm{GABA}_{\mathrm{A}}$ receptors. Trends Pharmacol Sci 1997;18(11):425-9. [PubMed: 9426470]

15. Saarelainen KS, Ranna M, Rabe H, Sinkkonen ST, Moykkynen T, Uusi-Oukari M, Linden AM, Luddens H, Korpi ER. Enhanced behavioral sensitivity to the competitive GABA agonist, gaboxadol, in transgenic mice over-expressing hippocampal extrasynaptic alpha6beta GABA(A) receptors. J Neurochem. 2007

16. Korpi ER, Luddens H. Furosemide interactions with brain GABAA receptors. Br J Pharmacol 1997;120(5):741-8. [PubMed: 9138676]

17. Korpi ER, Kuner T, Seeburg PH, Luddens H. Selective antagonist for the cerebellar granule cellspecific gamma- aminobutyric acid type A receptor. Mol Pharmacol 1995;47(2):283-9. [PubMed: 7870036]

18. Korpi ER, Wong G, Luddens H. Subtype specificity of gamma-aminobutyric acid type A receptor antagonism by clozapine. Naunyn Schmiedebergs Arch Pharmacol 1995;352(4):365-73. [PubMed: 8532064]

19. Barbee JG. Memory, benzodiazepines, and anxiety: integration of theoretical and clinical perspectives. J Clin Psychiatry 1993;54(Suppl):86-97. [PubMed: 8262893]discussion 98-101

20. Salinas JA, McGaugh JL. Muscimol induces retrograde amnesia for changes in reward magnitude. Neurobiol Learn Mem 1995;63(3):277-85. [PubMed: 7670841]

21. Huang Q, Liu R, Zhang P, He X, McKernan R, Gan T, Bennett DW, Cook JM. Predictive models for GABAA/benzodiazepine receptor subtypes: studies of quantitative structure-activity relationships for imidazobenzodiazepines at five recombinant GABAA/benzodiazepine receptor subtypes [alphaxbeta3gamma2 $(\mathrm{x}=1-3,5$, and 6)] via comparative molecular field analysis. J Med Chem 1998;41(21):4130-42. [PubMed: 9767648]

22. Huang Q, He X, Ma C, Liu R, Yu S, Dayer CA, Wenger GR, McKernan R, Cook JM. Pharmacophore/ receptor models for GABA(A)/BzR subtypes (alpha1beta3gamma2, alpha5beta3gamma2, and alpha6beta3gamma2) via a comprehensive ligand-mapping approach. J Med Chem 2000;43(1):7195. [PubMed: 10633039]

23. Li X, Cao H, Zhang C, Furtmueller R, Fuchs K, Huck S, Sieghart W, Deschamps J, Cook JM. Synthesis, in vitro affinity, and efficacy of a bis 8-ethynyl-4H-imidazo[1,5a]-[1,4]benzodiazepine analogue, the first bivalent alpha5 subtype selective BzR/GABA(A) antagonist. J Med Chem 2003;46 (26):5567-70. [PubMed: 14667209]

24. Cook JB, Foster KL, Eiler WJ 2nd, McKay PF, Woods J 2nd, Harvey SC, Garcia M, Grey C, McCane S, Mason D, Cummings R, Li X, Cook JM, June HL. Selective GABAA alpha5 benzodiazepine inverse agonist antagonizes the neurobehavioral actions of alcohol. Alcohol Clin Exp Res 2005;29 (8):1390-401. [PubMed: 16131846]

25. Albaugh PA, Marshall L, Gregory J, White G, Hutchison A, Ross PC, Gallagher DW, Tallman JF, Crago M, Cassella JV. Synthesis and biological evaluation of 7,8,9,10-tetrahydroimidazo[1,2-c] pyrido[3,4-e]pyrimdin-5(6H)-ones as functionally selective ligands of the benzodiazepine receptor site on the GABA(A) receptor. J Med Chem 2002;45(23):5043-51. [PubMed: 12408715]

26. Collins I, Moyes C, Davey WB, Rowley M, Bromidge FA, Quirk K, Atack JR, McKernan RM, Thompson SA, Wafford K, Dawson GR, Pike A, Sohal B, Tsou NN, Ball RG, Castro JL. 3Heteroaryl-2-pyridones: benzodiazepine site ligands with functional delectivity for alpha 2/alpha 3subtypes of human GABA(A) receptor-ion channels. J Med Chem 2002;45(9):1887-900. [PubMed: 11960500]

27. Mitchinson A, Atack JR, Blurton P, Carling RW, Castro JL, Curley KS, Russell MG, Marshall G, McKernan RM, Moore KW, Narquizian R, Smith A, Street LJ, Thompson SA, Wafford K. 2,5Dihydropyrazolo[4,3-c]pyridin-3-ones: functionally selective benzodiazepine binding site ligands on the GABAA receptor. Bioorg Med Chem Lett 2004;14(13):3441-4. [PubMed: 15177449] 
28. Yasumatsu H, Morimoto Y, Yamamoto Y, Takehara S, Fukuda T, Nakao T, Setoguchi M. The pharmacological properties of Y-23684, a benzodiazepine receptor partial agonist. Br J Pharmacol 1994;111(4):1170-8. [PubMed: 7913372]

29. Haefely W, Martin JR, Schoch P. Novel anxiolytics that act as partial agonists at benzodiazepine receptors. Trends Pharmacol Sci 1990;11(11):452-6. [PubMed: 1980040]

30. Grunwald C, Rundfeldt C, Lankau HJ, Arnold T, Hofgen N, Dost R, Egerland U, Hofmann HJ, Unverferth K. Synthesis, pharmacology, and structure-activity relationships of novel imidazolones and pyrrolones as modulators of GABAA receptors. J Med Chem 2006;49(6):1855-66. [PubMed: 16539371]

31. Krogsgaard-Larsen P, Frolund B, Jorgensen FS, Schousboe A. GABAA receptor agonists, partial agonists, and antagonists. Design and therapeutic prospects. J Med Chem 1994;37(16):2489-505. [PubMed: 8057295]

32. Rabe H, Picard R, Uusi-Oukari M, Hevers W, Lüddens H, Korpi ER. Coupling between agonist and chloride ionophore sites of the GABA(A) receptor: agonist/antagonist efficacy of 4-PIOL. Eur J Pharmacol 2000;409(3):233-42. [PubMed: 11108817]

33. Byberg JR, Labouta IM, Falch E, Hjeds H, Krogsgaard-Larsen P, Curtis DR, Gynther BD. Synthesis and biological activity of a GABAA agonist which has no effect on benzodiazepine binding and of structurally related glycine antagonists. Drug Des Deliv 1987;1(4):261-74. [PubMed: 2855566]

34. Frolund B, Jensen LS, Storustovu SI, Stensbol TB, Ebert B, Kehler J, Krogsgaard-Larsen P, Liljefors T. 4-aryl-5-(4-piperidyl)-3-isoxazolol GABAA antagonists: synthesis, pharmacology, and structureactivity relationships. J Med Chem 2007;50(8):1988-92. [PubMed: 17375905]

35. Krehan D, Storustovu SI, Liljefors T, Ebert B, Nielsen B, Krogsgaard-Larsen P, Frolund B. Potent 4-arylalkyl-substituted 3-isothiazolol GABA(A) competitive/noncompetitive antagonists: synthesis and pharmacology. J Med Chem 2006;49(4):1388-96. [PubMed: 16480274]

36. Frolund B, Jensen LS, Guandalini L, Canillo C, Vestergaard HT, Kristiansen U, Nielsen B, Stensbol TB, Madsen C, Krogsgaard-Larsen P, Liljefors T. Potent 4-aryl- or 4-arylalkyl-substituted 3isoxazolol GABA(A) antagonists: synthesis, pharmacology, and molecular modeling. J Med Chem 2005;48(2):427-39. [PubMed: 15658856]

37. Frolund B, Tagmose L, Jorgensen AT, Kristiansen U, Stensbol TB, Liljefors T, Krogsgaard-Larsen P. Design and synthesis of a new series of 4-alkylated 3-isoxazolol GABA A antagonists. Eur J Med Chem 2003;38(4):447-9. [PubMed: 12750034]

38. Mortensen M, Frolund B, Jorgensen AT, Liljefors T, Krogsgaard-Larsen P, Ebert B. Activity of novel 4-PIOL analogues at human alpha 1 beta 2 gamma 2 S GABA(A) receptors--correlation with hydrophobicity. Eur J Pharmacol 2002;451(2):125-32. [PubMed: 12231381]

39. Frolund B, Jorgensen AT, Tagmose L, Stensbol TB, Vestergaard HT, Engblom C, Kristiansen U, Sanchez C, Krogsgaard-Larsen P, Liljefors T. Novel class of potent 4-arylalkyl substituted 3isoxazolol GABA(A) antagonists: synthesis, pharmacology, and molecular modeling. J Med Chem 2002;45(12):2454-68. [PubMed: 12036354]

40. Frolund B, Kristiansen U, Brehm L, Hansen AB, Krogsgaard-Larsen P, Falch E. Partial GABAA receptor agonists. Synthesis and in vitro pharmacology of a series of nonannulated analogs of 4,5,6,7tetrahydroisoxazolo[5,4-c]pyridin-3-ol. J Med Chem 1995;38(17):3287-96. [PubMed: 7650683]

41. Akabas MH, Stauffer DA, Xu M, Karlin A. Acetylcholine receptor channel structure probed in cysteine-substitution mutants. Science 1992;258(5080):307-10. [PubMed: 1384130]

42. Sigel E, Baur R, Kellenberger S, Malherbe P. Point mutations affecting antagonist affinity and agonist dependent gating of $\mathrm{GABA}_{\mathrm{A}}$ receptor channels. Embo J 1992;11(6):2017-23. [PubMed: 1376242]

43. Hartvig L, Lukensmejer B, Liljefors T, Dekermendjian K. Two conserved arginines in the extracellular N-terminal domain of the GABA(A) receptor alpha(5) subunit are crucial for receptor function. J Neurochem 2000;75(4):1746-53. [PubMed: 10987858]

44. Westh-Hansen SE, Witt MR, Dekermendjian K, Liljefors T, Rasmussen PB, Nielsen M. Arginine residue 120 of the human GABAA receptor alpha 1, subunit is essential for GABA binding and chloride ion current gating. Neuroreport 1999;10(11):2417-21. [PubMed: 10439474]

45. Smith GB, Olsen RW. Identification of a $\left[{ }^{3} \mathrm{H}\right]$ muscimol photoaffinity substrate in the bovine gammaaminobutyric acidA receptor alpha subunit. J Biol Chem 1994;269(32):20380-7. [PubMed: 8051133] 
46. Holden JH, Czajkowski C. Different residues in the GABAA receptor alpha 1T60-alpha 1K70 region mediate GABA and SR-95531 actions. J Biol Chem 2002;277(21):18785-92. [PubMed: 11896052]

47. Boileau AJ, Evers AR, Davis AF, Czajkowski C. Mapping the agonist binding site of the GABA receptor: evidence for a beta-strand. J Neurosci 1999;19(12):4847-54. [PubMed: 10366619]

48. Kloda JH, Czajkowski C. Agonist-, antagonist-, and benzodiazepine-induced structural changes in the alpha1 Met113-Leu132 region of the GABAA receptor. Mol Pharmacol 2007;71(2):483-93. [PubMed: 17108261]

49. Celie PH, van Rossum-Fikkert SE, van Dijk WJ, Brejc K, Smit AB, Sixma TK. Nicotine and carbamylcholine binding to nicotinic acetylcholine receptors as studied in AChBP crystal structures. Neuron 2004;41(6):907-14. [PubMed: 15046723]

50. Aranda G, Dessolin M, Golfier M, Guillerez MG. ${ }^{13}$ C NMR Study of some Derivatives of 1,3,4Oxadiazoles, 1,3,4-Thiadiazoles and Isosydnones. Org Magn Res 1982;18:159-164.

51. Roberts DD, Lewis SD, Ballou DP, Olson ST, Shafer JA. Reactivity of small thiolate anions and Cysteine-25 in papain towards methylmethanethiosulfonate. Biochemistry 1986;25:5595-5601. [PubMed: 3778876]

52. Horenstein J, Akabas MH. Location of a high affinity $\mathrm{Zn}^{2+}$ binding site in the channel of alpha1beta1 gamma-aminobutyric acid A receptors. Mol Pharmacol 1998;53(5):870-7. [PubMed: 9584213]

53. Baumann SW, Baur R, Sigel E. Subunit arrangement of gamma-aminobutyric acid type A receptors. J Biol Chem 2001;276(39):36275-80. [PubMed: 11466317]

54. Frolund B, Tagmose L, Liljefors T, Stensbol TB, Engblom C, Kristiansen U, Krogsgaard-Larsen P. A novel class of potent 3-isoxazolol GABA(A) antagonists: design, synthesis, and pharmacology. J Med Chem 2000;43(26):4930-3. [PubMed: 11150163]

55. Krogsgaard-Larsen P, Mikkelsen H, Jacobsen P, Falch E, Curtis DR, Peet MJ, Leah JD. 4,5,6,7Tetrahydroisothiazolo[5,4-c]pyridin-3-ol and related analogues of THIP. Synthesis and biological activity. J Med Chem 1983;26(6):895-900. [PubMed: 6304315]

56. Brejc K, van Dijk WJ, Smit AB, Sixma TK. The 2.7 A structure of AChBP, homologue of the ligandbinding domain of the nicotinic acetylcholine receptor. Novartis Found Symp 2002;245:22-9. [PubMed: 12027010]discussion 29-32, 165-8

57. Cromer BA, Morton CJ, Parker MW. Anxiety over GABA(A) receptor structure relieved by AChBP. Trends Biochem Sci 2002;27(6):280-7. [PubMed: 12069787]

58. Brejc K, van Dijk WJ, Klaassen RV, Schuurmans M, van Der Oost J, Smit AB, Sixma TK. Crystal structure of an ACh-binding protein reveals the ligand-binding domain of nicotinic receptors. Nature 2001;411(6835):269-76. [PubMed: 11357122]

59. Wagner DA, Czajkowski C. Structure and dynamics of the GABA binding pocket: A narrowing cleft that constricts during activation. J Neurosci 2001;21(1):67-74. [PubMed: 11150321]

60. Jin R, Banke TG, Mayer ML, Traynelis SF, Gouaux E. Structural basis for partial agonist action at ionotropic glutamate receptors. Nat Neurosci 2003;6(8):803-10. [PubMed: 12872125]

61. Aboul-Enein MN, Azzouny AA, Abdallah NA, El-Shabrawy Makhlouf AA, Werner W. Synthesis of Certain 5-Piperidyl-1,3,4-Oxadiazol-2(3H)-ones and -2(3H)-thiones having Nonulcerogenic. Antiinflammatory and Analgesic Activities. Sci Pharm 1995;(63):175-190.

62. Bentley KW, Burton M, Uff BC. 1,3,4-Oxadiazol-2(3H)-one Formation from N-Acylaminobiurets and Related Compounds and from S-Benzyl 3-Acyl(thiocarbazates). J Chem Soc Perkin Trans I 1982;9:2019-2021.

63. Dornow AKB. Notiz über die Darstellung von 1.3.4-Oxadiazolon-(5) und seinen C2-alkylierten Derivaten. Chem Ber 1949;82:121-123.

64. Hoggarth E. 2-Benzoyldithiocarbazinic Acid and Related Compounds. J Chem Soc Perkin Trans I 1952:4811-4817.

65. Horning DE, Muchowski JM. Five-membered Heterocyclic Thiones. Part I. 1,3,4-Oxadiazol-2thione. Can J Chem 1972;50:3079-3083.

66. Korpi ER, Luddens H. Regional gamma-aminobutyric acid sensitivity of t-butylbicyclophosphoro [35S]thionate binding depends on gamma- aminobutyric acidA receptor alpha subunit. Mol Pharmacol 1993;44(1):87-92. [PubMed: 8393526]

67. Luddens H, Korpi ER. GABA antagonists differentiate between recombinant GABAA/ benzodiazepine receptor subtypes. J Neurosci 1995;15(10):6957-62. [PubMed: 7472452] 
68. Pritchett DB, Seeburg PH. Gamma-aminobutyric acidA receptor alpha 5-subunit creates novel type II benzodiazepine receptor pharmacology. J Neurochem 1990;54(5):1802-4. [PubMed: 2157817]

69. Hamill OP, Marty A, Neher E, Sakmann B, Sigworth FJ. Improved patch-clamp techniques for highresolution current recording from cells and cell-free membrane patches. Pflugers Arch 1981;391(2): 85-100. [PubMed: 6270629]

70. Horenstein J, Wagner DA, Czajkowski C, Akabas MH. Protein mobility and GABA-induced conformational changes in $\mathrm{GABA}_{A}$ receptor pore-lining M2 segment. Nat Neurosci 2001;4(5):47785. [PubMed: 11319555]

71. Schwede T, Kopp J, Guex N, Peitsch MC. SWISS-MODEL: An automated protein homologymodeling server. Nucleic Acids Res 2003;31(13):3381-5. [PubMed: 12824332]

72. Bali M, Akabas MH. Defining the propofol binding site location on the GABAA receptor. Mol Pharmacol 2004;65(1):68-76. [PubMed: 14722238] 

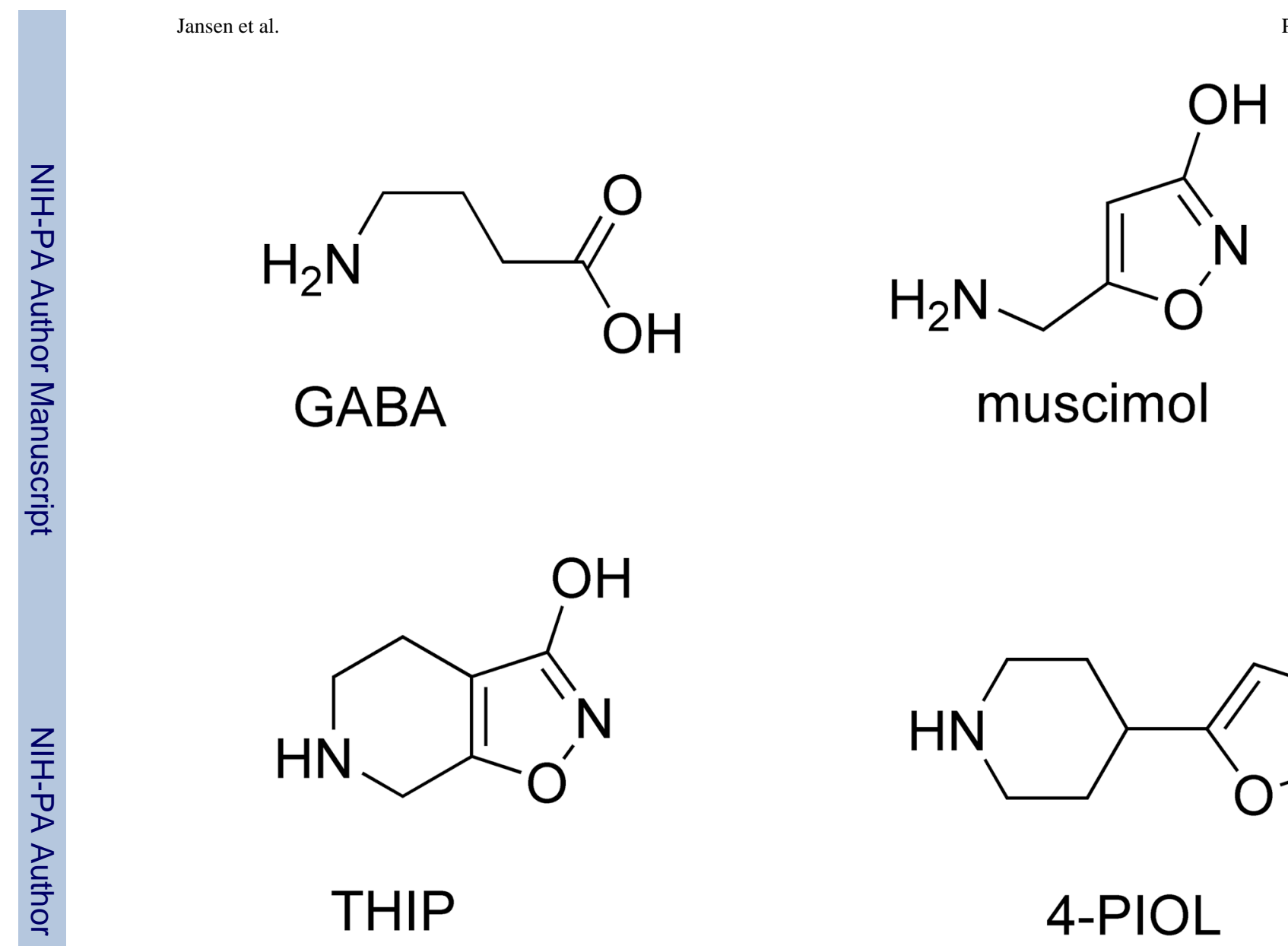

Figure 1.

Structures of GABA, muscimol, THIP and 4-PIOL.

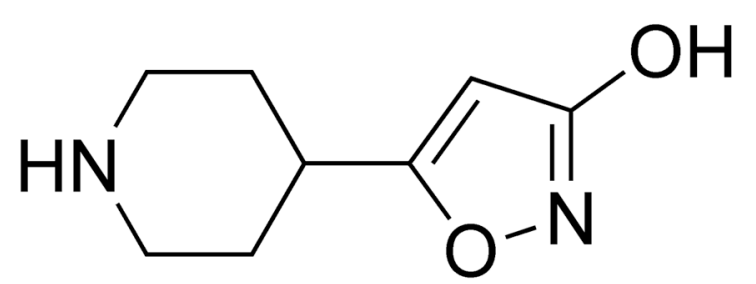

4-PIOL 

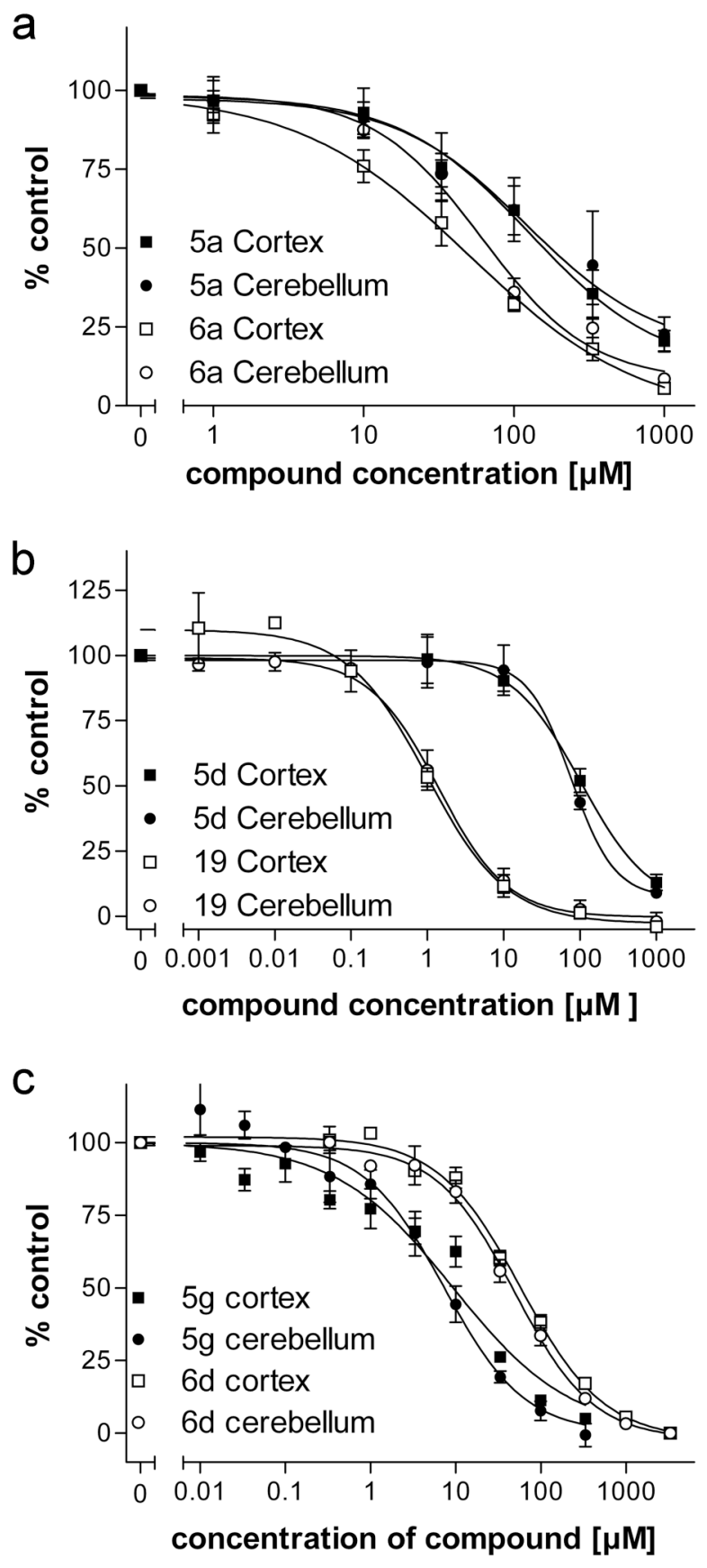

Figure 2.

Dose-response curves as measured against $\left[{ }^{3} \mathrm{H}\right]$ muscimol binding to cortical (squares) and cerebellar (circles) membranes. Binding data were normalized to the binding in the absence of any inhibitor set to $100 \%$. Error bars indicate the S.E.M for at least three independent tissue preparations. 


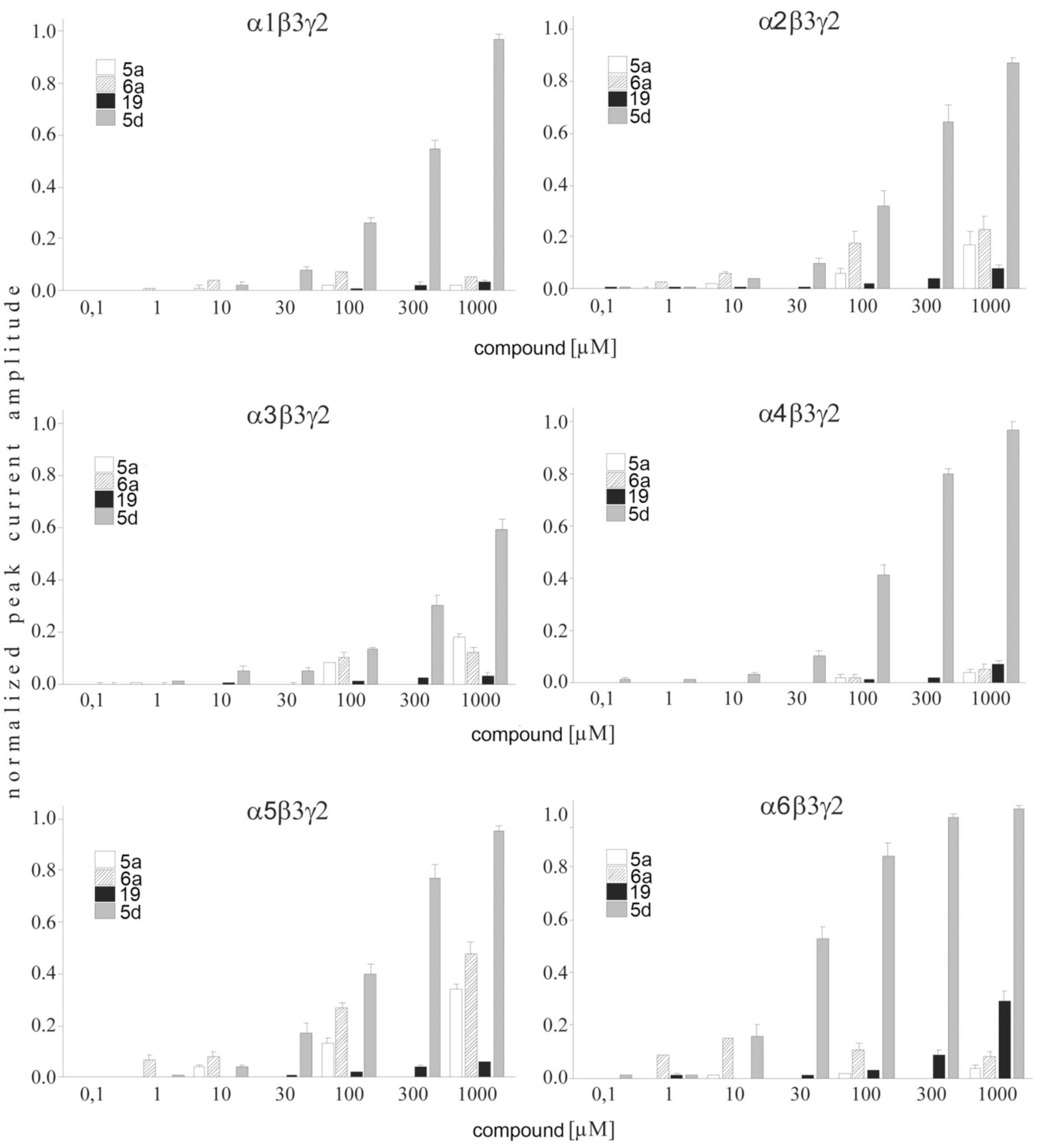

Figure 3.

Whole-cell recordings of HEK 293 cells expressing recombinant rat $\alpha_{i} \beta_{3} \gamma_{2}(i=1-6)$

$\mathrm{GABA}_{\mathrm{A}}$ receptors. Currents were normalized to the maximally GABA-induced current at the approximate $\mathrm{EC}_{100}$. To test the intrinsic activity, different concentrations of the 5-(4piperidyl)-1,3,4-oxadiazol-derivates tested were applied to the cells. Error bars indicate the S.E.M for at least four cells. 


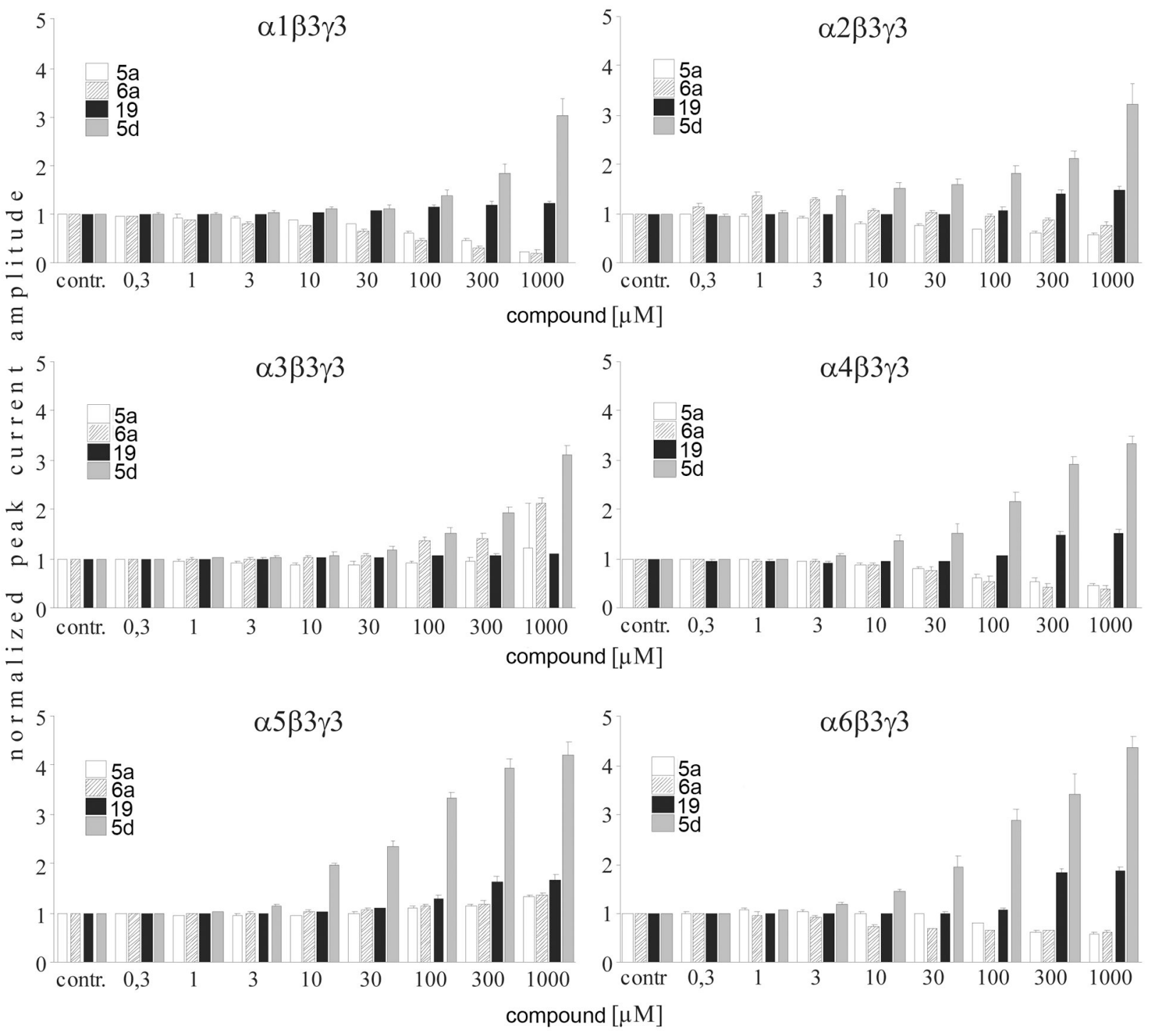

Figure 4.

Whole-cell recordings of HEK 293 cells expressing recombinant rat $\alpha_{i} \beta_{3} \gamma_{2}(i=1-6)$

$\mathrm{GABA}_{\mathrm{A}}$ receptors. Currents were normalized to the GABA concentrations specific for the receptor subtype under in vitro conditions. Different concentrations of the 5-(4piperidyl)-1,3,4-oxadiazol-derivates tested were co-applied with GABA concentrations around the $\mathrm{EC}_{25}$. Error bars indicate the S.E.M for at least four cells. 

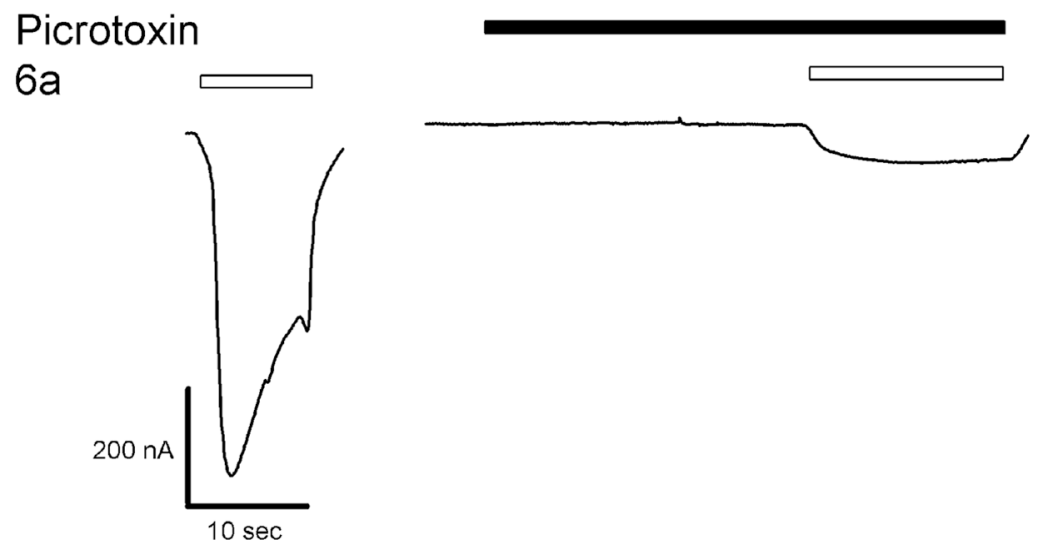

Figure 5.

Picrotoxinin blocks $6 \mathbf{a}$ induced currents in $\alpha_{1} \beta_{2}$ wt receptors. The first trace shows a $\mathbf{6} \mathbf{a}$ induced current. The second trace was recorded during a $20 \mathrm{~s}$ application of picrotoxinin, immediately followed by a co-application of $\mathbf{6} \mathbf{a}$ and picrotoxinin. 

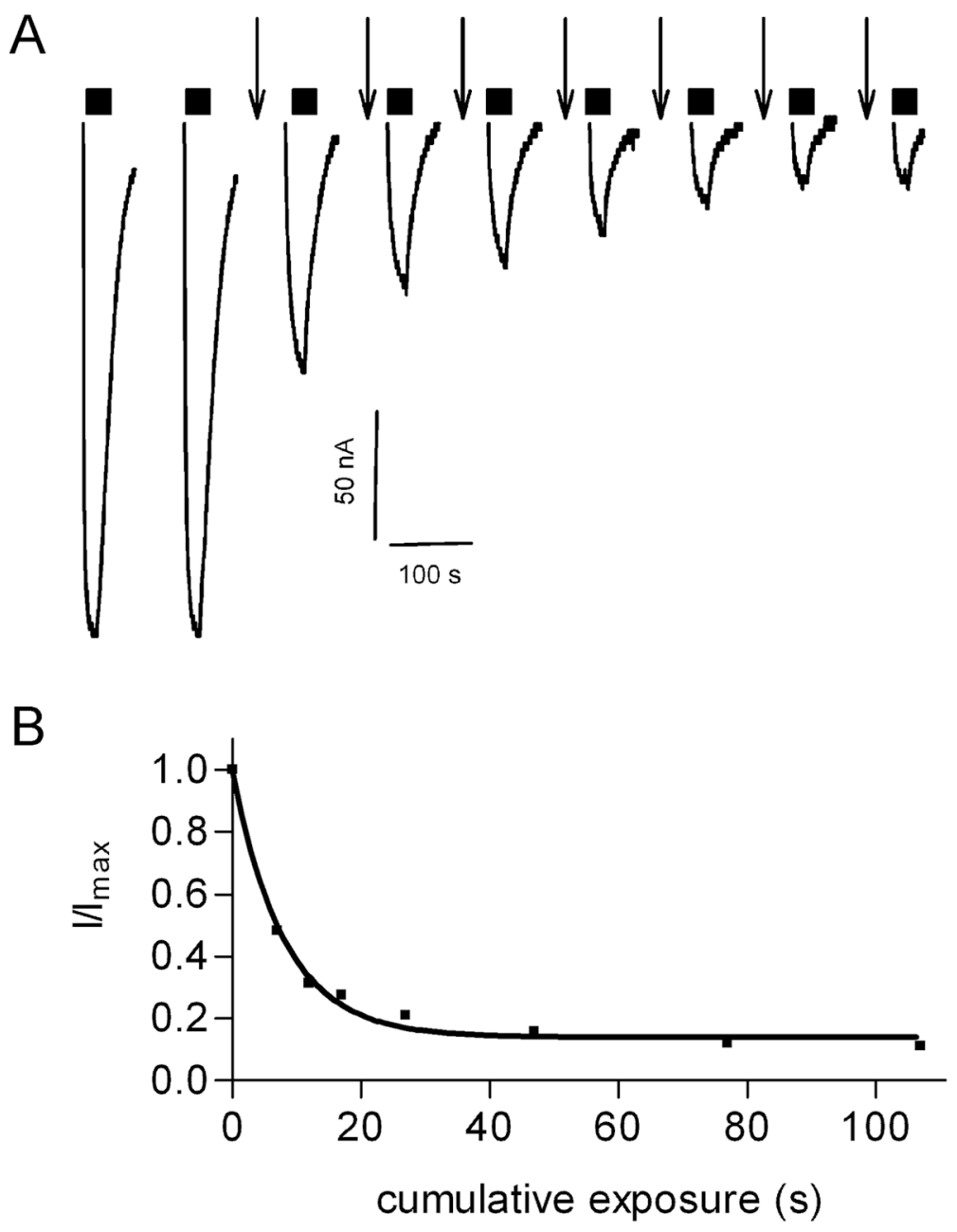

Figure 6.

$\mathrm{MTSES}^{-}$reaction rate with the $\alpha_{1} \mathrm{~F} 64 \mathrm{C} \beta_{2}$ cysteine mutant. A, EC ${ }_{50}$ GABA current traces were recorded initially and after each brief application of $10 \mu \mathrm{M} \mathrm{MTSES}^{-}(\downarrow)$. Currents during MTSES $^{-}$application $(\downarrow)$ are not shown. B, GABA test currents were normalized to the initial GABA current $\left(\mathrm{I}_{\max }\right)$ and plotted versus cumulative MTSES $^{-}$exposure time. Data were fit to a monoexponential decay function. 
A
B
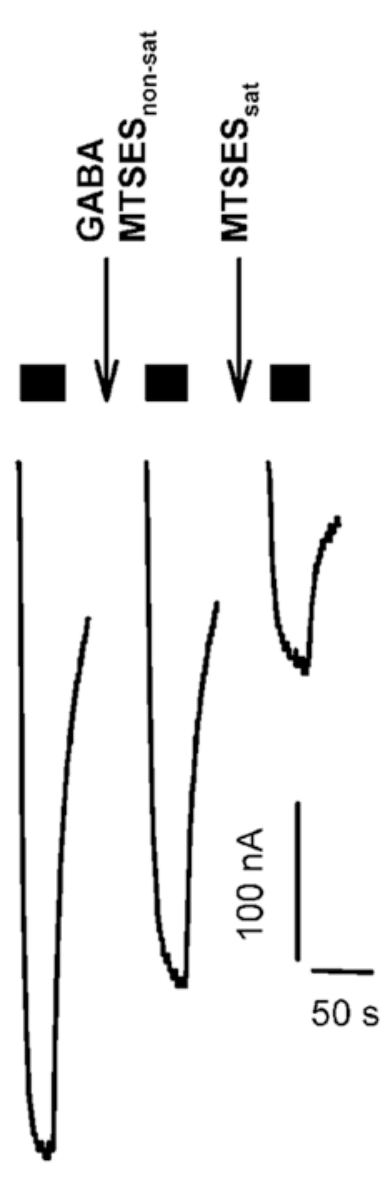

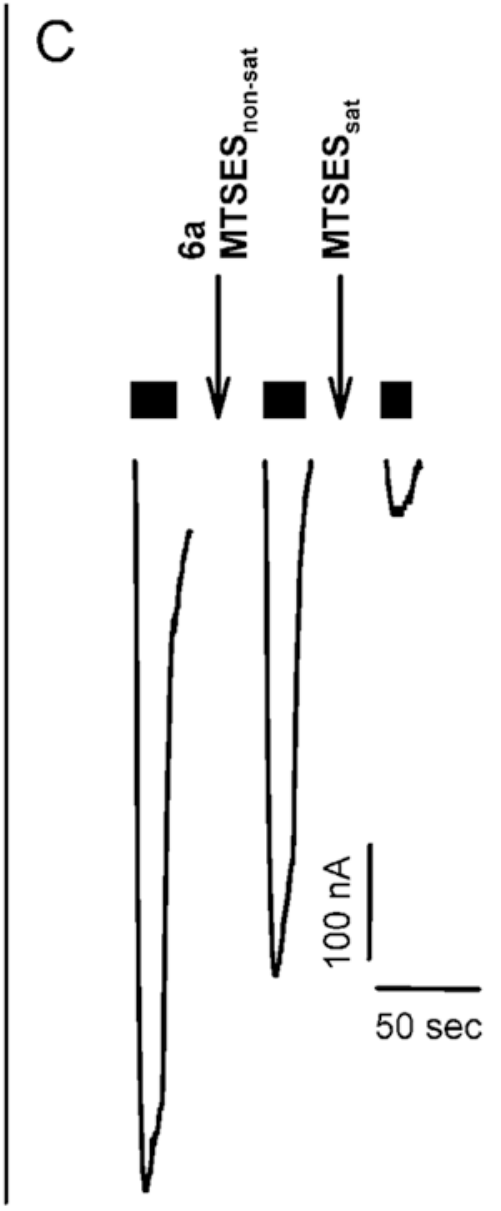

Figure 7.

Protection assay shows that GABA and $\mathbf{6 a}$ protect $\alpha_{1} \mathrm{~F} 64 \mathrm{C} \beta_{2}$ receptors from reaction with MTSES $^{-}$. A, MTSES ${ }^{-}$modification of $\alpha_{1}$ F64C $_{2}$ in the absence of agonist. Two GABA test pulses were applied to demonstrate the stability of the GABA current. At the downward arrow

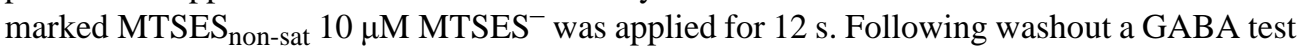
pulse was recorded. The GABA test current (third trace) was reduced by $87 \%$. At the downward arrow marked MTSES $_{\mathrm{sat}} 20 \mu \mathrm{M} \mathrm{MTSES}^{-}$was applied for $50 \mathrm{~s}$ to bring the $\mathrm{MTSES}^{-}$reaction to completion. Following washout a final GABA test pulse (fourth trace) was applied. Currents during MTSES $^{-}$applications $(\downarrow)$ are not shown. B, GABA protects $\alpha_{1}$ F64C $\beta_{2}$ from modification by MTSES $^{-}$. The same series of reagents are applied as in panel A, except that the MTSES $_{\text {non-sat }}$ was coapplied with 3.6 mM GABA. The GABA current elicited by the next GABA test pulse (middle trace) is significantly larger than the GABA current after the MTSES $_{\text {non-sat }}$ application in panel A, indicating that the presence of GABA significantly reduced the extent of reaction with the non-saturating concentration of MTSES ${ }^{-}$. C, $6 \mathbf{a}$ protects $\alpha_{1}$ F64C $\beta_{2}$ from modification by MTSES $^{-}$. The same series of reagents are applied as in panel

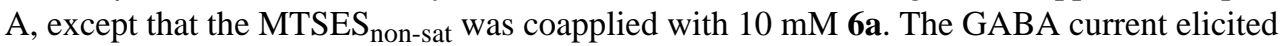
by the next GABA test pulse (middle trace) is significantly larger than the GABA current after the MTSES $_{\text {non-sat }}$ application in panel A, indicating that the presence of 6 a significantly reduced the extent of reaction with the non-saturating concentration of MTSES ${ }^{-}$. Currents during MTSES $^{-}$application $(\downarrow)$ with or without agonist are not shown. Duration of application of $\mathrm{GABA} \mathrm{EC}_{50}$ test pulses are indicated by black horizontal bars above the current traces. 


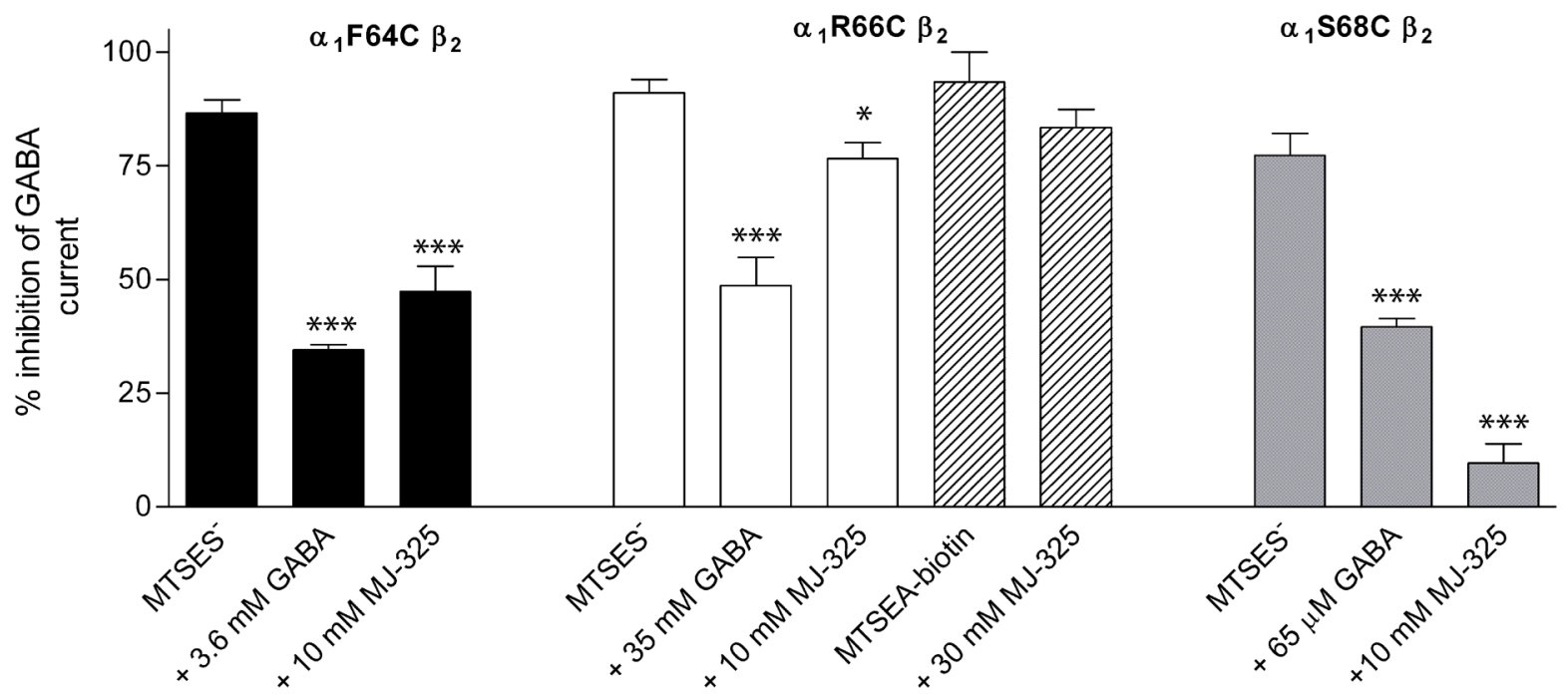

Figure 8.

Summary of the protection assay with $\alpha_{1} \mathrm{~F} 64 \mathrm{C} \beta_{2}$ (black bars), $\alpha_{1} \mathrm{R} 66 \mathrm{C} \beta_{2}$ (clear and striped bars), and $\alpha_{1} \mathrm{~S} 68 \mathrm{C} \beta_{2}$ (grey bars). Bars indicate the average percent inhibition of GABA test currents following the application of a non-saturating concentration of MTSES ${ }^{-}$either in the absence of agonist or in the presence of $\mathrm{EC}_{90} \mathrm{GABA}$ or $\mathbf{6 a}(10$ or $30 \mathrm{mM})$. We infer that a reagent, GABA or $\mathbf{6 a}$, protected a mutant from reaction with $\mathrm{MTSES}^{-}$if the extent of inhibition by MTSES $^{-}$coapplied with either GABA or $\mathbf{6 a}$ is significantly less than the extent of inhibition by MTSES $^{-}$applied alone. Conditions where the co-application of GABA or $\mathbf{6 a}$ are significantly different than the effect of $\mathrm{MTSES}^{-}$application alone are indicated by *; (*, $\mathrm{P}<0.014$; ***, $\mathrm{P}<0.0001$ ) by one way ANOVA and Fisher's PLSD. For $\alpha_{1} \mathrm{R} 66 \mathrm{C} \beta_{2} 30 \mu \mathrm{M}$ MTSEA-biotin reduced the subsequent GABA test currents by $93 \%$. Application of $30 \mu \mathrm{M}$ MTSEA-biotin with $30 \mathrm{mM}$ 6a reduced the subsequent GABA test currents by $83 \%$. The limited supply of $\mathbf{6 a}$ precluded further experiments. 


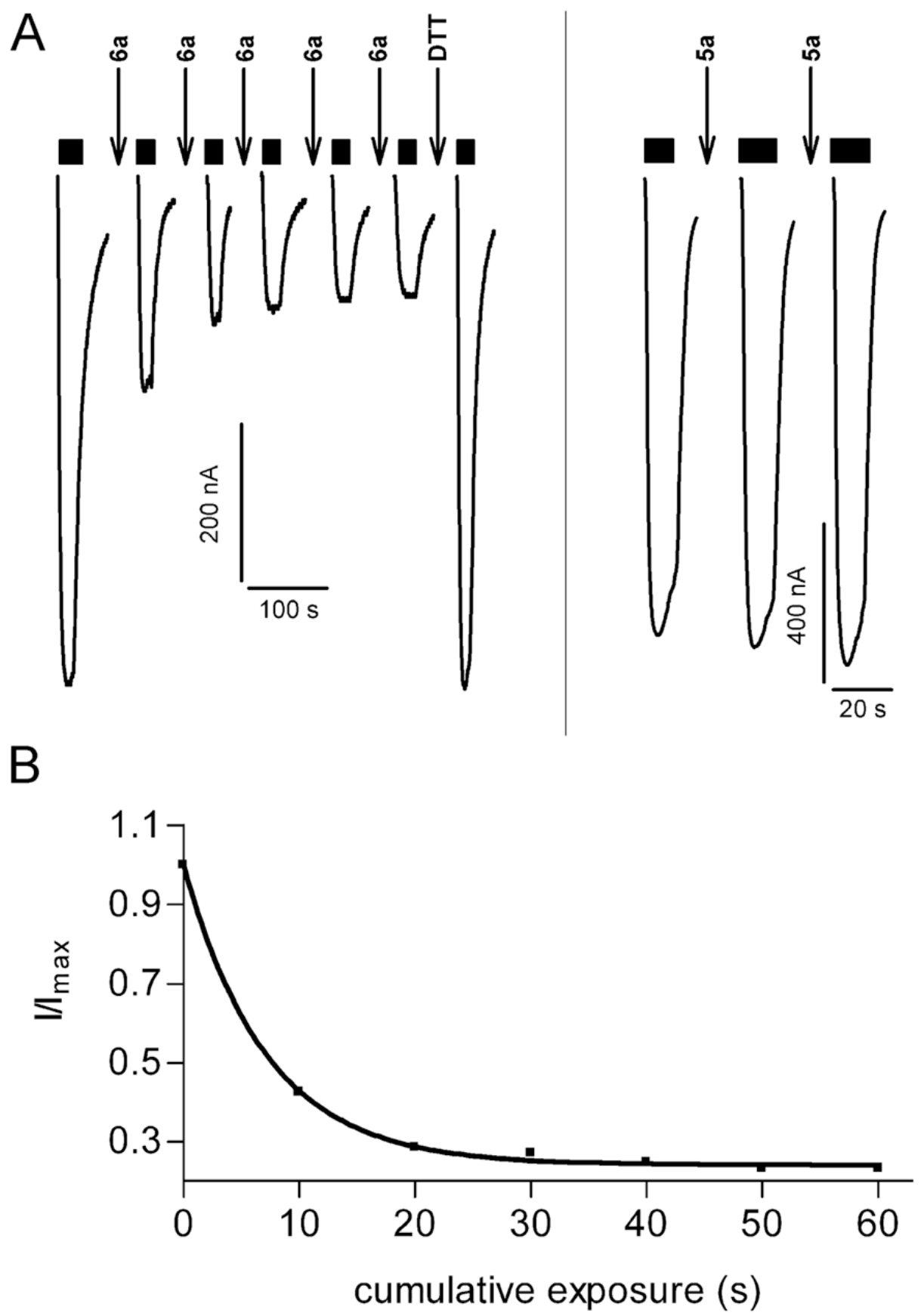

Figure 9.

6a reacted with $\alpha_{1}$ R66C $\beta_{2}$. A, Currents recorded from an oocyte expressing $\alpha_{1}$ R66C $\beta_{2}$. Alternating 10-s applications of $30 \mathrm{mM}$ 6a [indicated by $(\downarrow)$ ] and $5.5 \mathrm{mM}$ GABA test currents (bars above current traces) resulted in a progressive decrease in the GABA test currents. The decrease eventually plateaued at which time a 12-s application of $10 \mathrm{mM} \mathrm{MTSES}{ }^{-}(\downarrow)$ had no effect indicating that all accessible cysteine had reacted with 6a. Reduction by a $20-\mathrm{s}$ application of $10 \mathrm{mM}$ DTT $(\downarrow)$ led to complete recovery of the GABA test current magnitude. Currents during application of $\mathbf{6 a}$, MTSES $^{-}$and DTT are not shown. B, Application of the oxygen analogue 5a (30 mM, $10 \mathrm{~s})(\downarrow)$ to an oocyte expressing $\alpha_{1} \mathrm{R} 66 \mathrm{C} \beta_{2}$ did not decrease the subsequent GABA test currents. Currents during $\mathbf{5 a}$ application are not shown. $\mathbf{C}$, Reaction 
rate of $6 \mathbf{a}$ with $\alpha_{1} R 66 C \beta_{2}$. GABA test currents were normalized to the initial GABA test current, plotted as a function of cumulative duration of $\mathbf{6 a}$ application and fitted to a monoexponential decay function. 

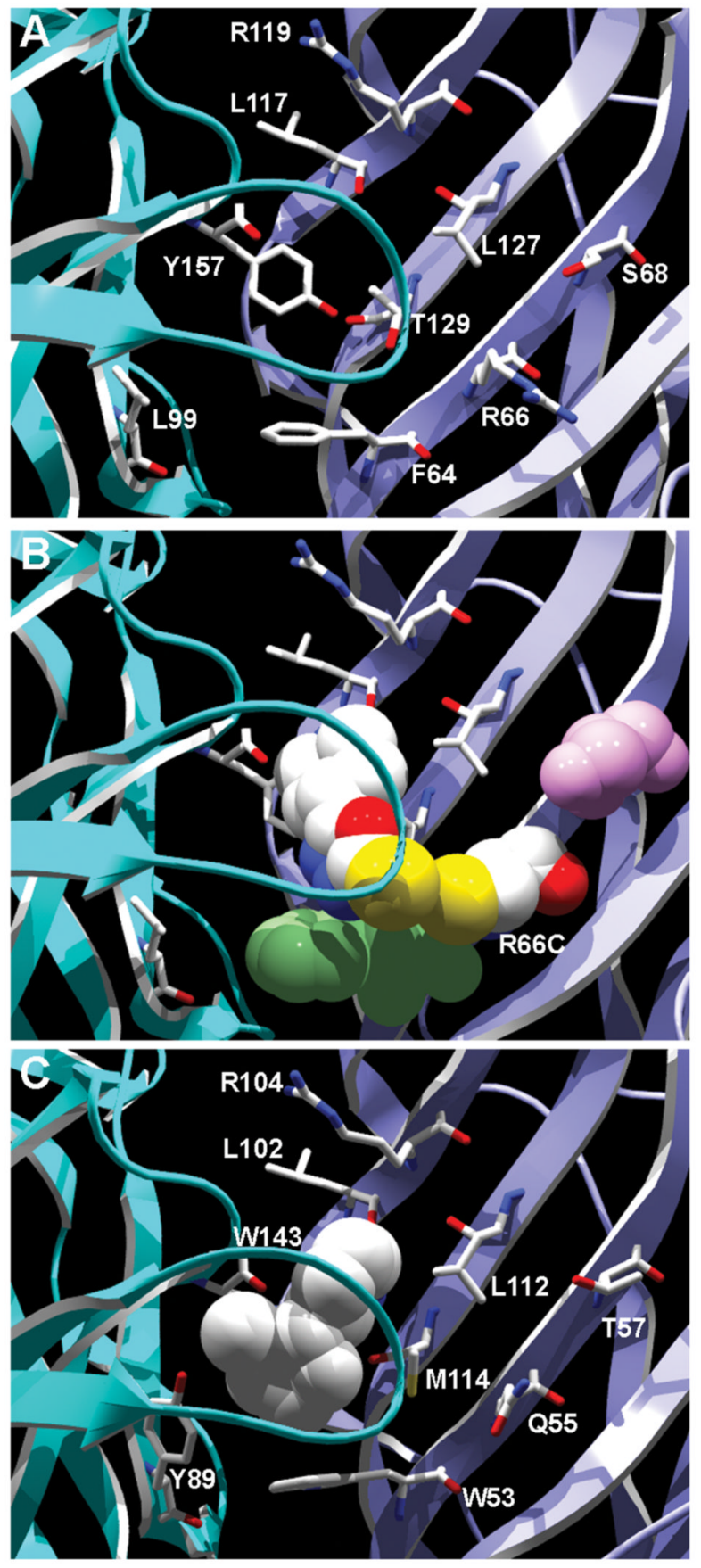

Figure 10.

Homology model of the $\mathrm{GABA}_{\mathrm{A}}$ receptor agonist binding site based on the AChBP structure (PDB 1UW6). A, View of the principle side of the $\beta_{2}$ subunit GABA binding site (light blue) and of the complementary side of the $\alpha_{1}$ subunit GABA binding site (dark blue) showing backbone in ribbon form. Side chains of residues mentioned in the text are shown in wireframe format. B, GABA binding site showing backbone in ribbon form with $\mathbf{6 a}$ and $\alpha_{1}$ R66C shown in spacefilling format with CPK colors. The close proximity of the sulfurs (yellow) in $\mathbf{6 a}$ and $\alpha_{1}$ Cys66 is consistent with the observed reaction between $6 \mathbf{a}$ and $\alpha_{1}$ Cys66. $\alpha_{1}$ F64 is shown in green spacefilling format. The close proximity between $\alpha_{1} \mathrm{~F} 64$ and $\mathbf{6 a}$ is consistent with the steric protection of the cysteine substituted at this position. In contrast, $\alpha_{1} \mathrm{~S} 68$ (pink colored 
spacefilling format) is not in close proximity to 6 a. $\mathbf{C}$, View of nicotine bound in the $\mathrm{AChBP}$ binding site (PDB 1UW6) from the same perspective as in panel B. Backbone is shown in ribbon form and nicotine in white-color spacefilling format. Side chains of AChBP residues aligned with the $\mathrm{GABA}_{\mathrm{A}}$ cysteine mutants discussed in the text and shown in panel $\mathrm{C}$ are in wireframe format. Nicotine interacts with the homologous $\beta$ strand adjacent to the $\beta$ strand containing the residue in this model aligned with $\mathrm{GABA}_{\mathrm{A}} \alpha_{1}$ R66. 
A<smiles>Sc1nnc(C2CCNCC2)o1</smiles>

6a<smiles>Oc1nnc(C2CCNCC2)o1</smiles>

$5 a$<smiles>NCCCC(=O)O</smiles>

GABA<smiles>NCc1cc(O)no1</smiles>

muscimol

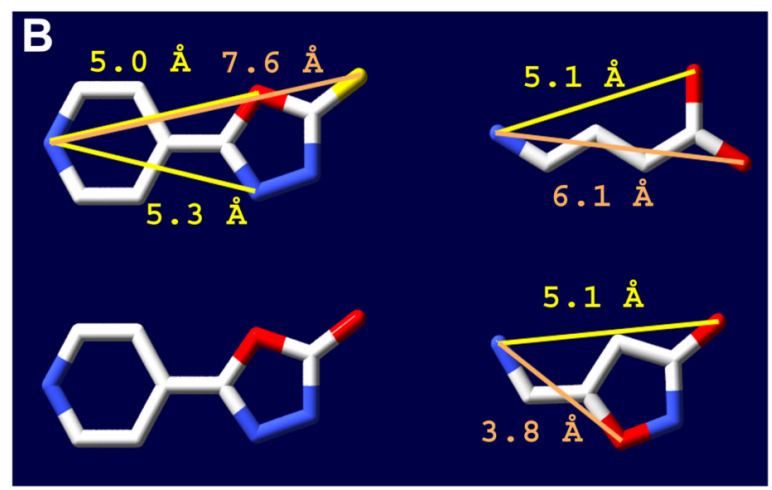

C
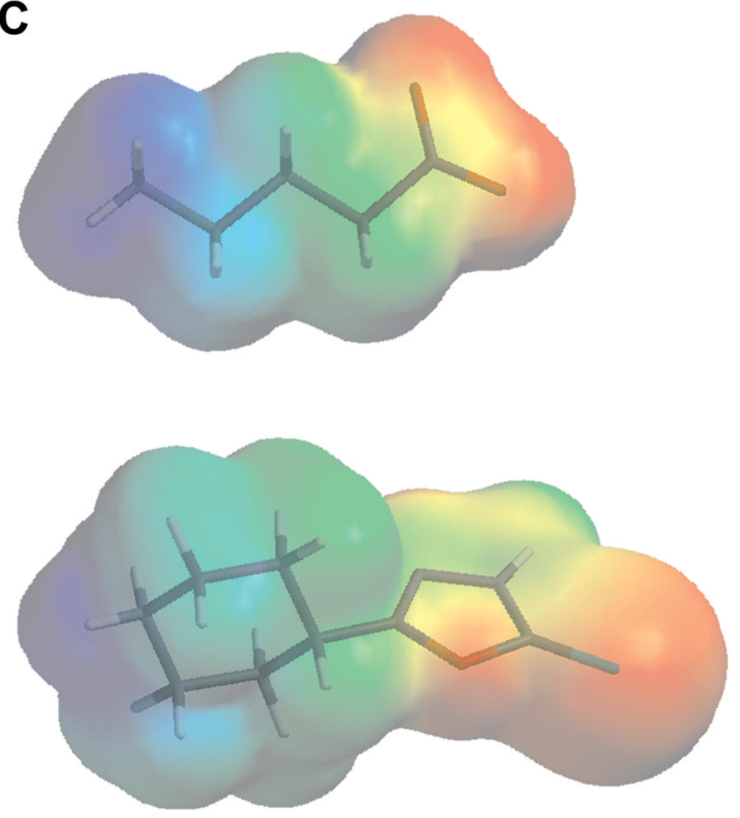

Figure 11.

A, Structures of 6a and 5a (left column) and of GABA and muscimol (right column). B, Structures of the compounds in panel A with atomic distances between the basic nitrogen atom and other polar atoms in the respective molecules. Distances were measured after energy minimization (Chemsketch 5.12, ACD Inc., Toronto, Ontario, Canada). CPK color scheme used, carbon, white; nitrogen, blue; oxygen, red; sulfur, yellow. C, Electrostatic potential mapped onto the van der Waals surface of GABA (top) and 6a (bottom) with stick representation of molecules. Red indicates negative electrostatic potential and blue is positive potential. Image generated using Spartan. Note the similarity of the overall electrostatic 
potential, especially the distance between the positively charged nitrogen in GABA or $\mathbf{6 a}$ to the negative carboxylate (GABA) or the oxadiazolthione moeity (6a). 

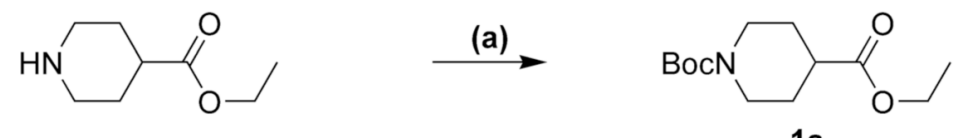

$1 a$
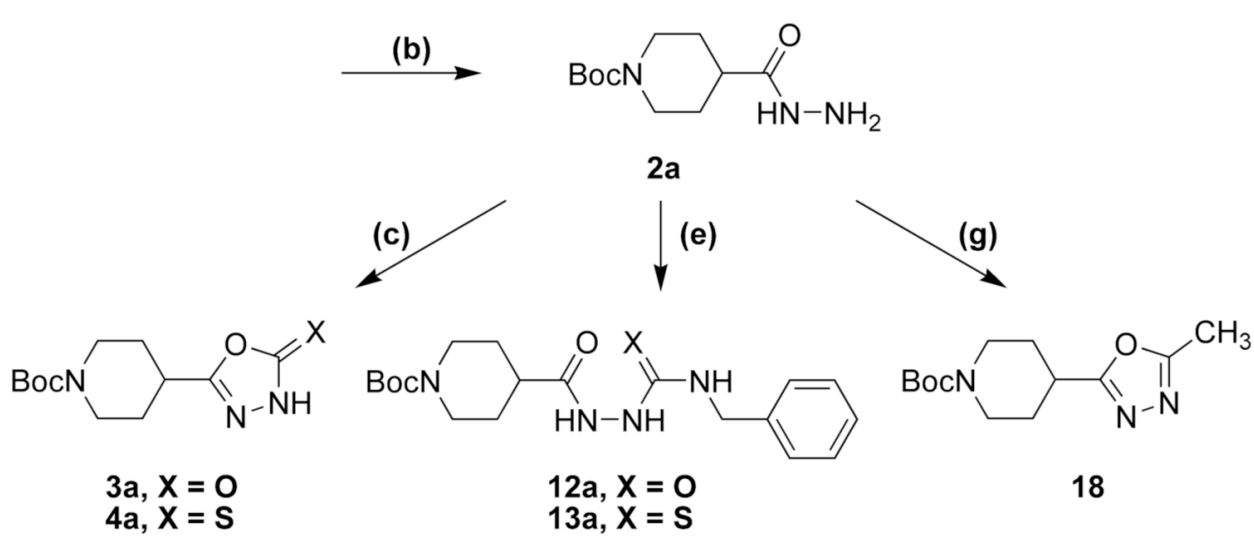

(d)

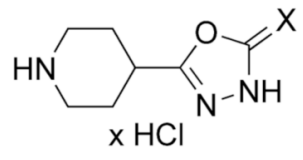

5a, $x=0$

$6 a, x=S$ $\downarrow$ (f)<smiles></smiles>

14, $X=0$

$15, X=S$

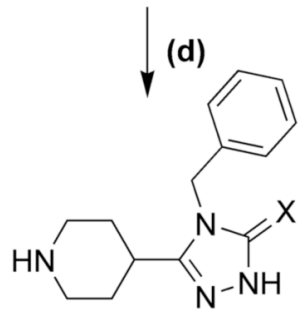

$x \mathrm{HCl}$

16a, $X=0$

17a, $X=S$

Scheme 1a.

$\boldsymbol{a}$ Reaction conditions: (a) $\mathrm{Et}_{3} \mathrm{~N}, \mathrm{Boc}_{2} \mathrm{O}$ in $\mathrm{CH}_{2} \mathrm{Cl}_{2}$ or $\mathrm{NaHCO}_{3}, \mathrm{Boc}_{2} \mathrm{O}$ in water; (b) $\mathrm{NH}_{2} \mathrm{NH}_{2}$; (c) CDI to obtain 3; $\mathrm{CS}_{2}$ to obtain 4; (d) $2.3 \mathrm{~N}$ ethanolic $\mathrm{HCl}$; (e) $\mathrm{PhCH}_{2} \mathrm{NCX}$; (f) $2 \% \mathrm{NaOH}$; (g) $\mathrm{H}_{3} \mathrm{CC}\left(\mathrm{OC}_{2} \mathrm{H}_{5}\right)_{3}$; (h) $\mathrm{HBr} / \mathrm{HAc}$. 

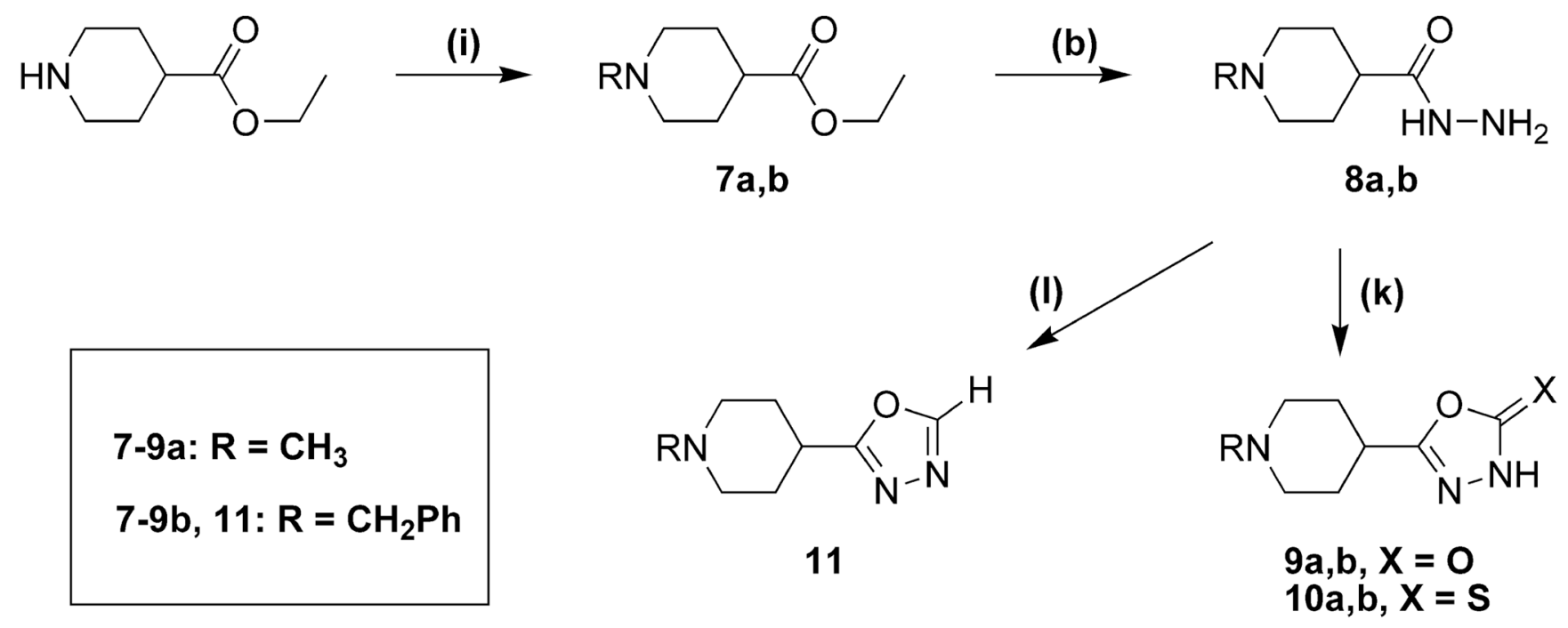

Scheme 2a.

$\boldsymbol{a}$ Reaction conditions: (b) $\mathrm{NH}_{2} \mathrm{NH}_{2}$; (i) $\mathrm{CH}_{2} \mathrm{O}, \mathrm{HCOOH}$ to obtain 7a; $\mathrm{PhCH}_{2} \mathrm{Cl}$ to obtain $7 \mathbf{b}$;

(k) triphosgene to obtain $\mathbf{9 a , b} ; \mathrm{CS}_{2}$ to obtain 10a,b; (l) $\mathrm{HC}\left(\mathrm{OC}_{2} \mathrm{H}_{5}\right)_{3}$. 
$\mathrm{R}^{1} \mathscr{O R}_{3}$<smiles>[R]OC([R])=O</smiles><smiles></smiles><smiles>C1CCCC1</smiles><smiles>[R]C(=O)NN</smiles><smiles>C[SiH2]C</smiles><smiles>[R]C1=NNC([X])O1</smiles><smiles>[GeH3]</smiles><smiles>[R]C1=NNC([X])O1</smiles>

1a-g

2a-g

3a-f, $X=0$

4a-e,g, $X=S$

$5 a-g, X=0$<smiles>[R]C(=O)NNC([X])NCc1ccccc1</smiles>

$12 a, d, x=0$

$13 a, d, X=S$
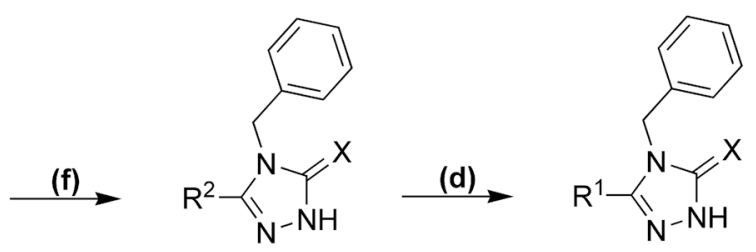

$14 a, d, X=0$

$15 a, d, X=s$

$16 a, d, X=0$

$17 a, d, X=S$

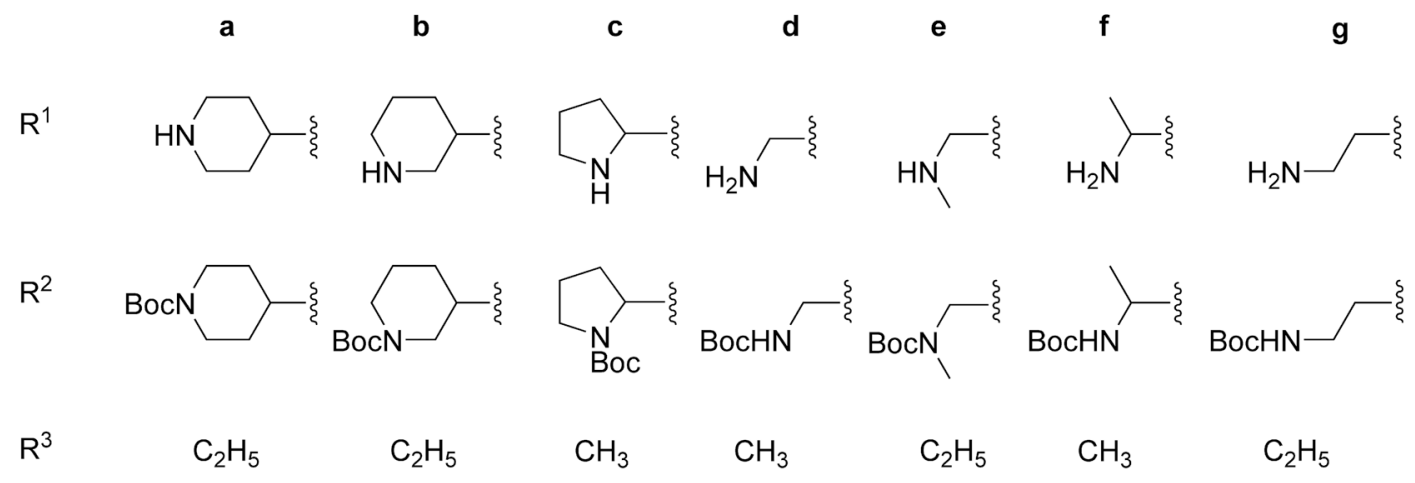

Scheme 3a.

${ }^{a}$ Reaction conditions as given in Scheme 1 and Scheme 2. 
<smiles>[R]C(=O)OCC</smiles>

$7 a-e$ (b)

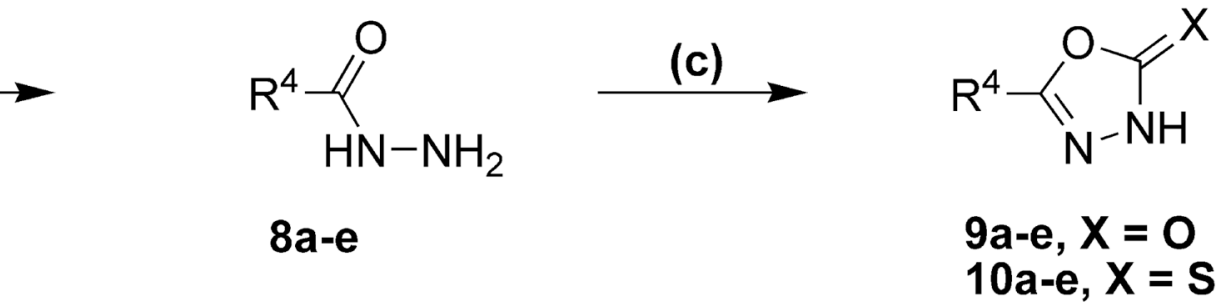

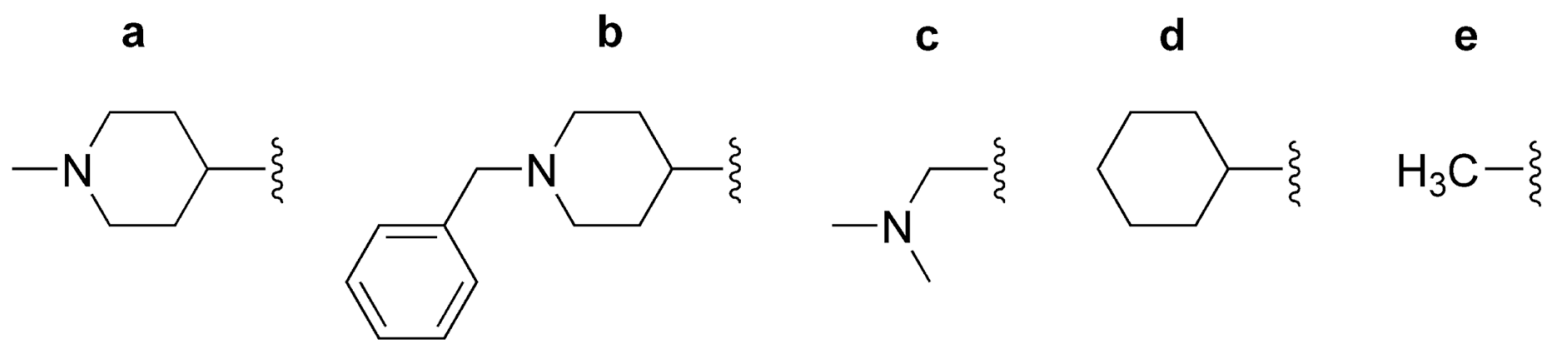

Scheme 4a.

${ }^{a}$ Reaction conditions as given in Scheme 1 and Scheme 2. 


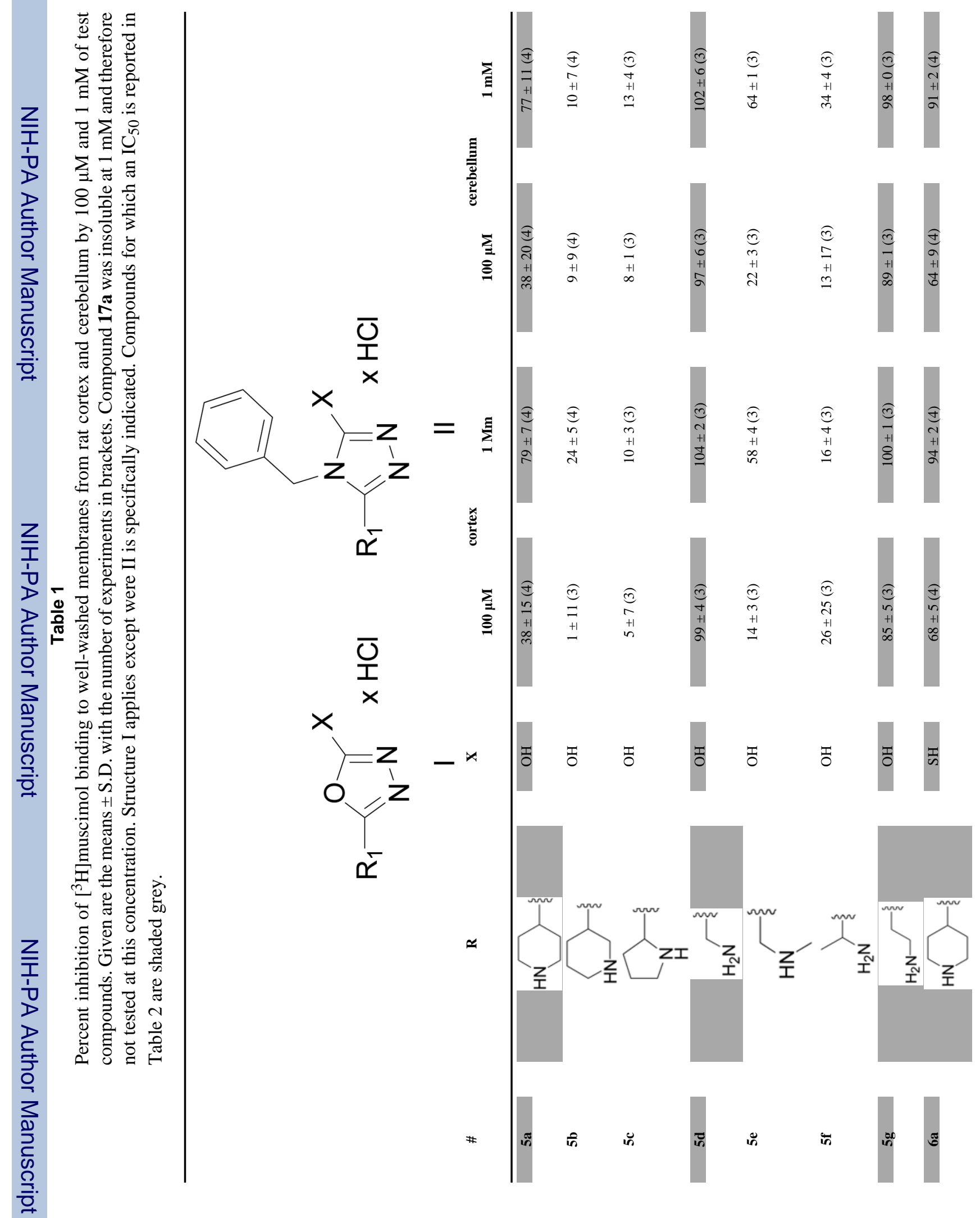

J Med Chem. Author manuscript; available in PMC 2008 October 13. 


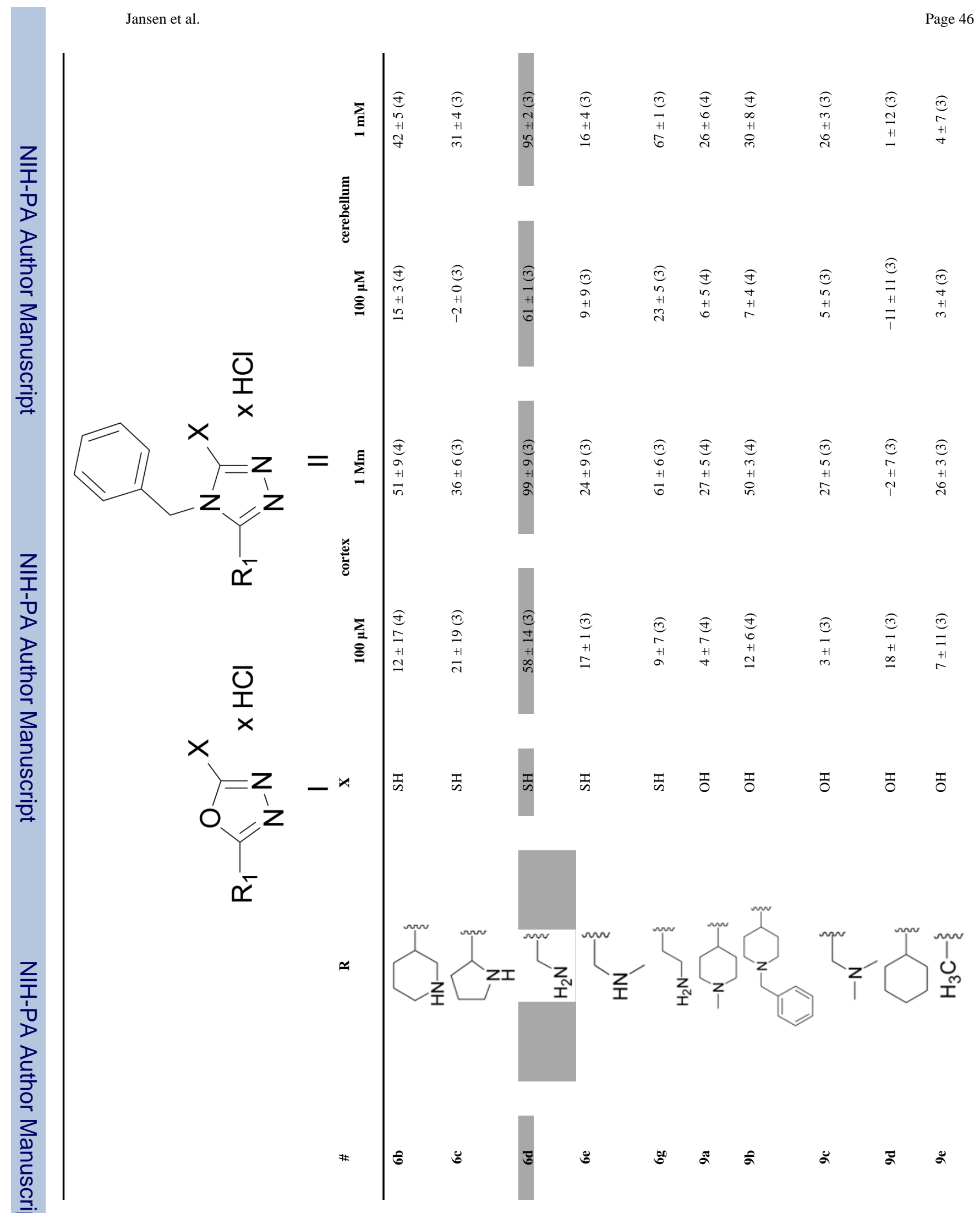

J Med Chem. Author manuscript; available in PMC 2008 October 13. 


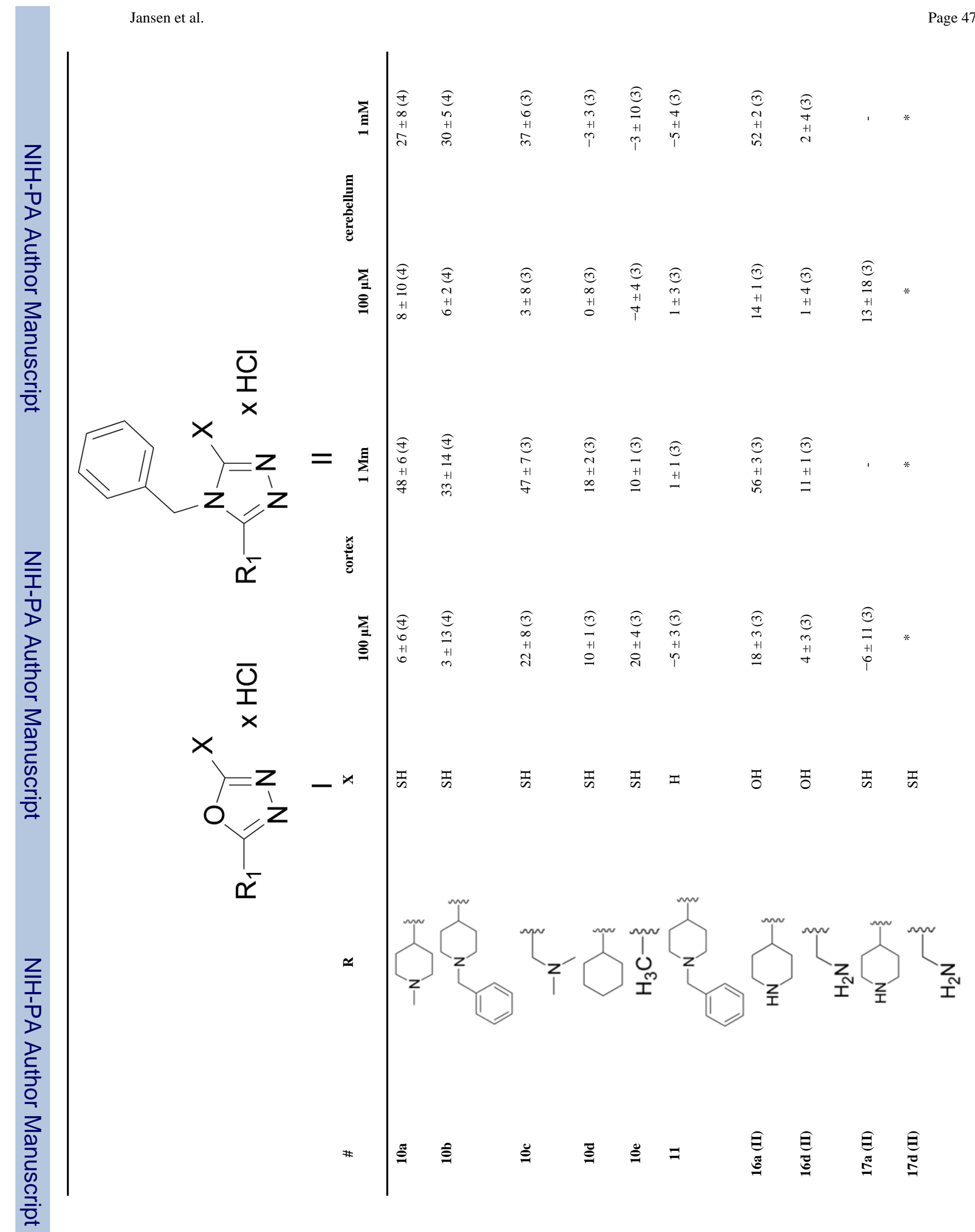

J Med Chem. Author manuscript; available in PMC 2008 October 13. 


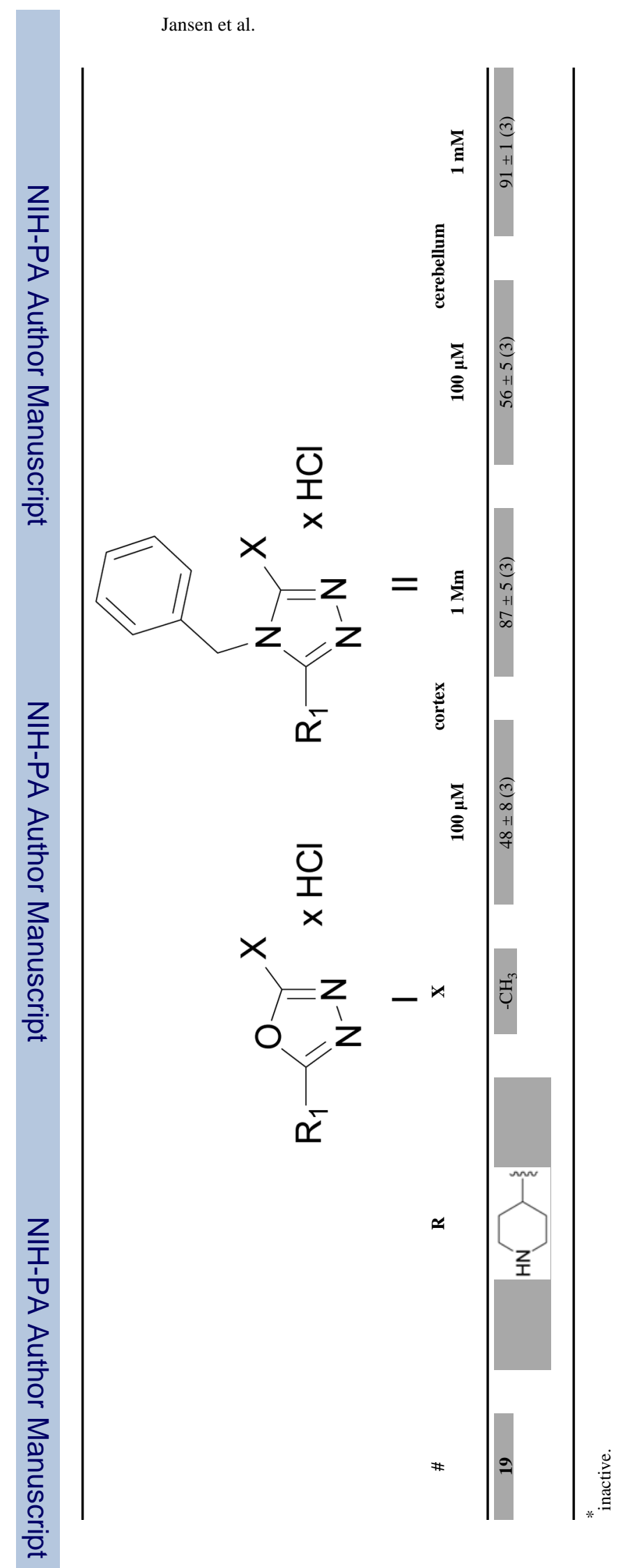

J Med Chem. Author manuscript; available in PMC 2008 October 13. 


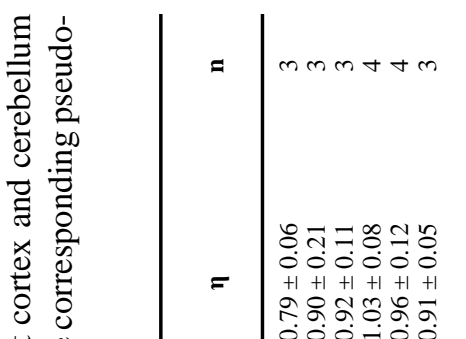

可

पे

.

i

은,

ज

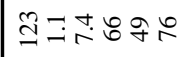

हैํㅠㄹ



Un ن门

tratmon

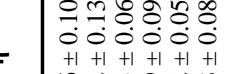
$\infty \simeq 62$ 0

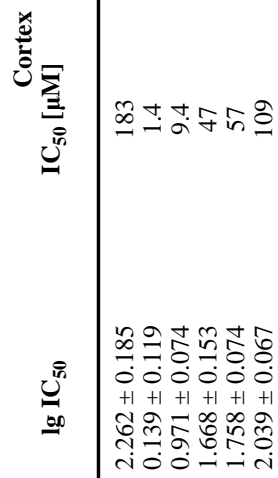

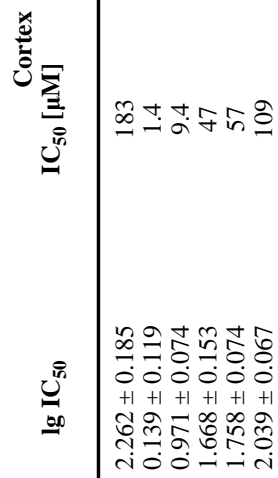

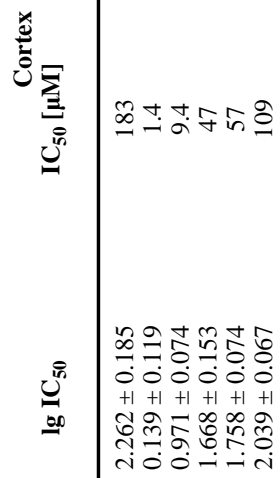

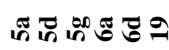




\section{Table 3}

GABA concentrations and the corresponding relative effective concentration that induces a response around the $\mathrm{EC}_{20}$ when applied to GABA $\mathrm{A}$ receptors $\alpha_{\mathrm{i}} \beta_{3} \gamma_{2}(\mathrm{i}=1-6)$ transiently expressed in HEK 293 cells. Given are the mean \pm S.E.M.

$\begin{array}{ccc}\text { asubunit } & \text { GABA }[\boldsymbol{\mu M}] & \text { EC } \\ \alpha_{1} & 2.0 & 25 \pm 2.3 \\ \alpha_{2} & 4.0 & 24 \pm 1.9 \\ \alpha_{3} & 8.0 & 22 \pm 2.1 \\ \alpha_{4} & 5.0 & 25 \pm 2.0 \\ \alpha_{5} & 3.0 & 22 \pm 2.1 \\ \alpha_{6} & 0.5 & 20 \pm 2.2\end{array}$


Table 4

Maximal intrinsic activity of $1 \mathrm{mM} 5 \mathbf{d}$ normalized to the approximate maximal GABA-induced current $\left(\mathrm{I} / \mathrm{I}_{\text {maxGABA}}\right)$ and the $5 \mathbf{d} \mathrm{EC}_{50}$ and Hill coefficient on $\alpha_{\mathrm{i}} \beta_{3} \gamma_{2}(\mathrm{i}=1-6) \mathrm{GABA}_{\mathrm{A}}$ receptors. Data are means \pm S.E.M.

$\begin{array}{cccc}\text { asubunit } & \mathbf{I}_{\text {maxGABA }} & \mathbf{E C}_{\mathbf{5 0}}[\boldsymbol{\mu M}] & \text { Hill } \\ \alpha_{1} & 0.93 \pm 0.03 & 280 \pm 17 & 0.99 \pm 0.05 \\ \alpha_{2} & 0.88 \pm 0.02 & 182^{*} & 1.23^{*} * \\ \alpha_{3} & 0.59 \pm 0.04 & 2300^{*} & 0.81 \\ \alpha_{4} & 0.97 \pm 0.01 & 128 \pm 8 & 1.56 \pm 0.11 \\ \alpha_{5} & 0.95 \pm 0.03 & 137 \pm 14 & 1.31 \pm 0.12 \\ \alpha_{6} & 1.03 \pm 0.01 & 30 \pm 3 & 1.41 \pm 0.14\end{array}$

* marks values of an extrapolated dose-response curve. 


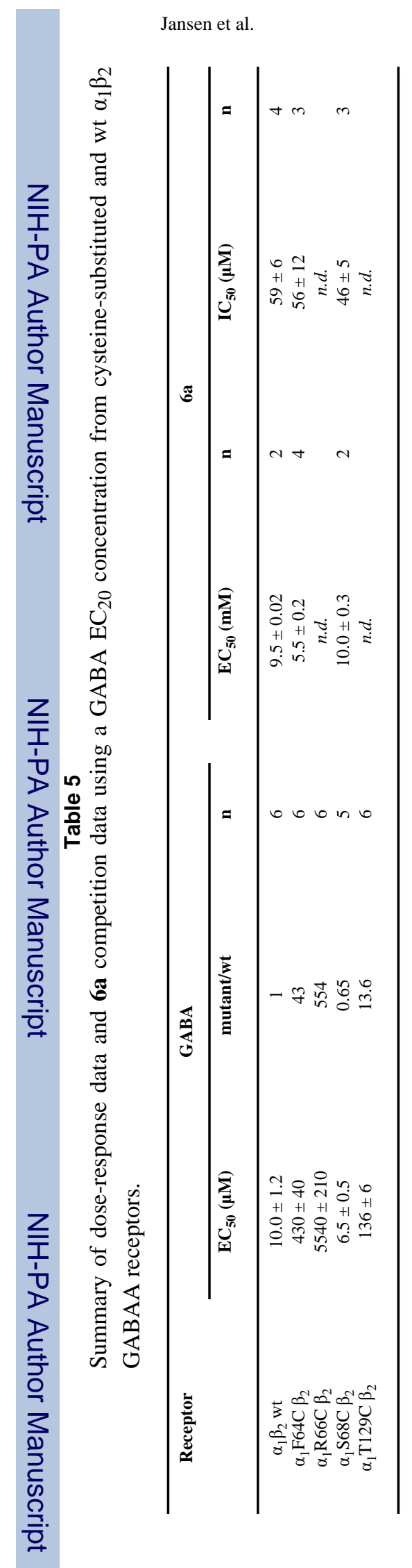

Page 52 


\section{Table 6}

Extent of inhibition of GABA-induced currents after reaction with MTS reagent.

\begin{tabular}{|c|r|r|r|r|}
\hline & $\boldsymbol{\alpha}_{1}$ F64C & $\boldsymbol{\alpha}_{1}$ R66C & $\boldsymbol{\alpha}_{1}$ S68C & $\boldsymbol{\alpha}_{1}$ T129C \\
\hline MTSES $^{-}$ & $89 \pm 3(4)$ & $62 \pm 3(4)$ & $60 \pm 10(3)$ & n. d. \\
\hline MTSEA-biotin & n. d. & $75 \pm 4(9)$ & n. d. & $60 \pm 3(6)$ \\
\hline
\end{tabular}

Inhibition (\% \pm S.E.M. (n)) for GABA EC50 currents after complete reaction with MTSES ${ }^{-}$and MTSEA-biotin on GABAA receptors containing the

cited cys-engineered $\alpha 1$ subunit together with the $\beta_{2}$ subunit expressed in Xenopus oocytes. n.d. = not determined. 


\section{Table 7}

MTS-reagent reaction rates.

\begin{tabular}{|c|c|c|c|}
\hline Receptor & MTS-reagent & Reaction Rate $\left[\mathrm{M}^{-1} / \mathrm{s}\right]$ & $\mathbf{n}$ \\
\hline$\alpha_{1} \mathrm{~F} 64 \mathrm{C} \beta_{2}$ & MTSES $^{-}$ & $11,300 \pm 700$ & 3 \\
\hline \multirow[t]{2}{*}{$\alpha_{1}$ R66C $\beta_{2}$} & MTSES $^{-}$ & $48 \pm 7$ & 5 \\
\hline & MTSEA-biotin & $5500 \pm 1600$ & 6 \\
\hline$\alpha_{1} \mathrm{~S} 68 \mathrm{C} \beta_{2}$ & MTSES $^{-}$ & $240 \pm 40$ & 4 \\
\hline$\alpha_{1} \mathrm{~T} 129 \mathrm{C} \beta_{2}$ & MTSEA-biotin & $6,700,000 \pm 1,100,000$ & 3 \\
\hline
\end{tabular}

